\title{
Consumo alimentar e metabolismo mineral e ósseo em mulheres idosas com sarcopenia.
}

\section{Patrícia de Souza Genaro}

Tese apresentada ao programa de Pós-Graduação em Saúde Pública para a obtenção do título de Doutor em Saúde Pública

Área de concentração: Nutrição

Orientadora: Profa. Assoc. Lígia Araújo Martini. Co-orientadora: Profa. Dra.Vera Lúcia Szejnfeld

São Paulo 


\section{Consumo alimentar e metabolismo mineral e ósseo em mulheres idosas com sarcopenia.}

\section{Patrícia de Souza Genaro}

Tese apresentada ao programa de Pós-Graduação em Saúde Pública da Faculdade de Saúde Pública da Universidade de São Paulo para a obtenção do título de Doutor em Saúde Pública.

Área de concentração: Nutrição

Orientadora: Profa. Assoc. Lígia Araújo Martini. Co-orientadora: Profa. Dra.Vera Lúcia Szejnfeld

São Paulo

2010 
Ë expressamente proibida a comercialização deste documento, tanto na sua forma impressa como eletrônica. Sua reprodução total ou parcial é permitida exclusivamente para fins acadêmicos e científicos, desde que na reprodução figure a identificação do autor, título, instituição e ano da tese. 


\section{Dedico esta tese}

A Lígia, minha orientadora, pela oportunidade de aprender a fazer ciência, pela dedicação, por me acolher como filha de sua alma e finalmente por acreditar que eu seria capaz.

Ao meu marido Marcelo, que teve toda a paciência do mundo nesta fase de vida, pelo amor e carinho. Meus pais Celso e Lourdes que sempre priorizaram nossa educação e pelos maiores ensinamentos de vida: honestidade, respeito e amor ao próximo. Meus irmãos Pablo e Priscila pelo amor e carinho. 


\section{Agradecimentos}

È grande a lista a quem devo agradecer, porém não é maior que toda a minha gratidão

A Dra. Vera Lúcia Szejnfeld pela oportunidade de poder participar do seu grupo de estudo sobre doenças ósteo-metabólicas e me receber com tanto carinho;

Ao Dr. Marcelo de Medeiro Pinheiro que com muito carinho e paciência me auxiliou nessa jornada e a quem eu considero um exemplo a ser seguido;

As pacientes que fizeram parte deste estudo, sem as quais seria impossível a realização dessa pesquisa;

As amigas de pós-graduação Giselle e Natielen pela amizade e pelas palavras de apoio e encorajamento que de alguma maneira me ajudaram a chegar ao fim desta jornada;

As amigas Bárbara, Karin, e Viviam pelo companheirismo e pelo conhecimento compartilhado;

As professoras Regina, Dirce e Sandra pelo conhecimento compartilhado;

Ao grupo de doenças ósteo-metabólicas Charles, Henrique, Luciana, Marcus, Usmary, Maria da Graça, Paulo, Claudio, Roberto pelos momentos de descontração e pelo conhecimento compartilhado;

As funcionárias da disciplina de Reumatologia Luzia, Neusa e Tereza pelo auxilio na coleta de dados;

Aos funcionários do Departamento de Nutrição da Faculdade de Saúde Pública USP e aos funcionários da Disciplina de Reumatologia que sempre ajudaram da melhor forma possível;

A Sr. Ricardo e a Neusa pelo incentivo, amor e carinho;

Ao Conselho Nacional de Desenvolvimento Científico e Tecnológico - CNPq e a Fundação de Amparo a Pesquisa - FAPESP, pelo apoio financeiro. 
"O que é valioso neste mundo não é nossa posição, nossa educação ou nosso conhecimento, mas nossa conduta e nosso comportamento baseados em valores espirituais. A conduta e o comportamento determinam o resultado que recebemos por nossos esforços. A educação verdadeira é amor, e nada além do amor. Sem amor, a vida não é digna de ser vivida". Sathya Sai Baba 


\section{RESUMO}

Genaro PS. Consumo alimentar e metabolismo mineral e ósseo em mulheres idosas com sarcopenia [tese de doutorado]. São Paulo: Faculdade de Saúde Pública da USP; 2010.

Introdução - a redução da massa muscular esquelética relacionada à idade, denominada sarcopenia, está associada com maior incidência de quedas, fraturas e dependência funcional em idosos. Muitos são os fatores que podem contribuir para o surgimento da sarcopenia, dentre eles a deficiência de vitamina $\mathrm{D}$ e a inadequação do consumo alimentar, principalmente a ingestão de proteína. Objetivos - investigar a relação da sarcopenia com o consumo alimentar e concentração sérica de 25(OH)D. Métodos - Foram avaliadas 200 mulheres acima de 65 anos, sendo 35 com sarcopenia e 165 sem sarcopenia. Avaliou-se a densidade mineral óssea (DMO) da coluna lombar, fêmur proximal e a composição corporal (massa muscular total, massa muscular esquelética, massa adiposa, conteúdo mineral ósseo do corpo total) por meio do densitômetro de dupla emissão com fonte de raios-X (DXA), avaliação radiográfica das colunas dorsal e lombar (T4 a L4). Foi realizada também avaliação da ingestão alimentar (diário de três dias), bioquímica do metabolismo mineral e ósseo (cálcio total, fósforo, creatinina, albumina, paratormônio intacto, calcidiol) e a história clínica das pacientes. Resultados - O presente estudo observou que as pacientes que apresentavam um consumo de proteína acima de 1,2g/kg/dia apresentaram massa muscular total $[33,94(4,72)$ vs $31,87(3,52) \mathrm{kg}, \mathrm{p}=0,020]$, massa muscular esquelética $[14,54(2,38)$ vs $13,38(1,95) \mathrm{kg}, \mathrm{p}=0,013]$, CMO do corpo total [1,945 (0,325) vs $1784(0,265) \mathrm{g}, \mathrm{p}=0,005]$, DMO de corpo total [1,039 $(0,109)$ vs $\left.0,988(0,090) \mathrm{g} / \mathrm{cm}^{2}, \mathrm{p}=0,011\right]$, DMO coluna lombar $[0,983(0,192)$ vs $0,903(0,131)$ $\left.\mathrm{g} / \mathrm{cm}^{2}, \mathrm{p}=0,014\right]$, DMO colo de fêmur $\left[0,813(0,117)\right.$ vs $0,760(0,944) \mathrm{g} / \mathrm{cm}^{2}$, $\mathrm{p}=0,017]$ e DMO fêmur total $\left[0,868(0,135)\right.$ vs $\left.0,807(0,116) \mathrm{g} / \mathrm{cm}^{2}, \mathrm{p}=0,026\right]$ significativamente maior quando comparado com pacientes que apresentavam consumo de proteína abaixo de $0,8 \mathrm{~g} / \mathrm{kg} / \mathrm{dia}$. Além disso, a ingestão de aminoácidos essenciais, principalmente os de cadeia ramificada como a valina $[3,10(0,89)$ vs 3,40 $(1,04) \mathrm{g} / \mathrm{dia}, \mathrm{p}=0,044]$ foi significantemente menor em mulheres com sarcopenia. $\mathrm{O}$ 
consumo de proteína se correlacionou positivamente com o índice de massa muscular esquelética $(\mathrm{r}=0,157 ; \mathrm{p}=0,028)$ e a DMO do trocânter $(\mathrm{r}=0,185 ; \mathrm{p}=0,010)$. Adicionalmente, a deficiência de vitamina D associados ao PTH elevado (> 65pg/dL), hiperparatiroidismo secundário, a prevalência de sarcopenia aumentada (77,1 vs 22,9\%, p=0,032), além disso mulheres com hiperparatiroidismo secundário apresentaram massa muscular total $[29,70(2,99)$ vs $31,84(3,65), p=0,043]$, índice de massa muscular esquelética $\left[\begin{array}{lllll}5,51 & (0,55) \text { vs } 5,92 \quad(0,78), \quad \mathrm{p}=0,043]\end{array}\right.$ significativamente menor. Alta prevalência de deficiência de vitamina D em mulheres com sarcopenia $(71,4 \%)$. As mulheres com deficiência de vitamina D apresentaram massa muscular total $[30,30(2,92)$ vs $32,14(3,84) \mathrm{kg}, \mathrm{p}=0,007]$, massa muscular esquelética apendicular [12,71 (1,59) vs 13,55 $(0,82) \mathrm{kg}, \mathrm{p}=0,031]$; índice de massa muscular esquelética $\left[5,67(0,60)\right.$ vs $\left.5,98(0,82) \mathrm{kg} / \mathrm{m}^{2}, \mathrm{p}=0,030\right]$ e fêmur total BMD [0,791 $(0,107)$ vs $\left.0,838(0,116) \mathrm{g} / \mathrm{cm}^{2}, \mathrm{p}=0,035\right]$ significativamente menor. Conclusões - A ingestão de proteínas acima $1,2 \mathrm{~g} / \mathrm{kg} / \mathrm{d}$, especialmente aminoácidos essenciais e suplementação de vitamina D deve ser considerada como terapia preventiva na redução da massa muscular e óssea em mulheres idosas.

Descritores: consumo de proteína, vitamina D, idosos, sarcopenia, composição corporal. 


\section{ABSTRACT}

Genaro PS. Consumo alimentar e metabolismo mineral e ósseo em mulheres idosas com sarcopenia/ Dietary intake and bone mineral metabolism in elderly women with sarcopenia [thesis]. São Paulo (BR): Faculdade de Saúde Pública da Universidade de São Paulo; 2010.

Introduction - Reduction of skeletal muscle mass, called sarcopenia, is associated with increased incidence of falls, fractures and functional dependence in the elderly. There are many factors that can contribute to the development of sarcopenia, among them the vitamin D deficiency and inadequate food intake, especially protein intake. Objectives - to investigate the relationship among sarcopenia, dietary intake and serum concentration of 25(OH)D. Methods - We evaluated 200 women over 65 years, 35 with sarcopenia and 165 without sarcopenia. Bone mineral density of lumbar spine, proximal femur and body composition (total muscle mass, skeletal muscle mass, fat mass, bone mineral content of the whole body) were assessed by Dual energy X-ray absorptiometry (DXA), radiological evaluation of the dorsal columns and lumbar (T4 to L4). Three-day dietary records were undertaken to estimate dietary intake and serum total albumin, calcium, phosphorus, creatinin, intact parathyroid hormone, 25(OH)D were measured. Results - Patients who presented protein intake above $1.2 \mathrm{~g} / \mathrm{kg} /$ day showed total muscle mass [33.94 (4.72) vs 31.87 (3.52) kg, p=0.020], muscle mass skeletal [14.54 (2.38) vs 13.38 (1.95) kg, $\mathrm{p}=0.013$ ], total body BMC [1.945 (0.325) vs 1784 (0.265) g, p=0.005], total body BMD [1.039 (0.109) vs $\left.0.988(0.090) \mathrm{g} / \mathrm{cm}^{2}, \mathrm{p}=0.011\right]$, lumbar spine BMD [0.983 (0.192) vs $\left.0.903(0.131) \mathrm{g} / \mathrm{cm}^{2}, \mathrm{p}=0.014\right]$, femoral neck BMD [0.813 (0.117) vs $\left.0.760(0.944) \mathrm{g} / \mathrm{cm}^{2}, \mathrm{p}=0.017\right]$ and total femur BMD [0.868 (0.135) vs $0.807(0.116)$ $\left.\mathrm{g} / \mathrm{cm}^{2}, \mathrm{p}=0.026\right]$ significantly higher when compared with patients who presented protein intake below $0.8 \mathrm{~g} / \mathrm{kg} / \mathrm{day}$. Essential amino acids intake, especially branched chain such as valine [3.10 (0.89) vs 3.40 (1.04) g/day, p=0.044] was significantly lower in women with sarcopenia. Protein intake positively correlated to skeletal muscle mass index $(\mathrm{r}=0.157, \mathrm{p}=0.028)$ and trochanter BMD $(\mathrm{r}=0.185, \mathrm{p}=0.010)$. Additionaly, presence of sarcopenia increases more than $20 \%$ when vitamin D 
deficiency is associated to PTH levels higher than 65pg/dL (77.1 vs 22.9\%; $\mathrm{p}=0.032$ ). Women with secondary hyperparathyroidism presented significantly lower total muscle mass [29.70 (2.99) vs 31.84 (3.65); p=0.043], SMMI [5.51 (0.55) vs 5.92 (0.78); $\mathrm{p}=0.043$ ]. it was also observed high prevalence of vitamin D deficiency in women with sarcopenia $(71.4 \%)$. Women with deficiency of vitamin D presented significantly lower TSMM [30.30 (2.92) vs 32.14 (3.84) kg; p=0.007], ASMM [12.71 (1.59) vs 13.55 (0.82) kg; p=0.031]; SMMI [5.67 (0.60) vs $5.98(0.82) \mathrm{kg} / \mathrm{m}^{2}$; $\mathrm{p}=0.030$ ] and total femur BMD [0.791 (0.107) vs $\left.0.838(0.116) \mathrm{g} / \mathrm{cm}^{2} ; \mathrm{p}=0.035\right]$. Conclusions - Protein intake above $1.2 \mathrm{~g} / \mathrm{kg} / \mathrm{d}$, particularly essencial amino acids and vitamin D supplementation should be considered as preventive therapy in reducing muscle and bone mass in elderly women.

Descriptors: protein intake, vitamin D, elderly, sarcopenia, body composition. 


\section{ÍNDICE}

1. APRESENTAÇÃO 15

2. INTRODUÇÃO 16

2.1 SARCOPENIA 16

2.1.1 Definição da sarcopenia 16

2.1.2 Epidemiologia da sarcopenia 16

$\begin{array}{lll}2.1 .3 & \text { Fisiopatologia da sarcopenia } & 18\end{array}$

2.1.4 Etiologia da sarcopenia 21

2.1.4.1 Consumo de proteína 22

2.1.4.2 Vitamina D 24

2.1.5 Consequiências da sarcopenia 27

3. OBJETIVOS 29

3.1 OBJETIVO GERAL 29

3.2 OBJETIVOS ESPECÍFICOS 29

4. MÉTODOS 30

4.1 DELINEAMENTO DO ESTUDO 30

4.2 POPULAÇÃO DO ESTUDO 30

4.2.1 Cálculo do tamanho amostral 30

4.2.2 Critérios de exclusão 31

4.3 PROTOCOLO DE ESTUDO 31

4.3.1 Avaliação da densidade óssea 32

4.3.2 Avaliação da composição corporal 32

4.3.3 Avaliação de força 33

4.3.4 Avaliação radiográfica 33

4.3.5 Avaliação laboratorial do metabolismo ósseo e 33 mineral

4.3.6 Avaliação do consumo alimentar 34

4.3.7 História clínica 35

4.3.8 Avaliação da capacidade funcional 36 
4.4 ANÁLISE ESTATÍTICA 37

4.5 ASPECTOS ÉTICOS 37

5. RESULTADOS 38

Artigo 1 - Protein Intake and its Effect on Bone and Muscle 38 mass in the elderly

Artigo 2 - Relação entre consumo de proteína, composição 60 corporal e massa óssea de mulheres com sarcopenia.

Artigo 3 - Insufficiency of vitamin D and its relation with 81 sarcopenia and bone mass in elderly women.

6. CONSIDERAÇÕES FINAIS 103

7. REFERÊNCIAS BIBLIOGRAFICAS 104

ANEXOS 114

Anexo I - Termo de consentimento livre e esclarecido 114

Anexo II - Registro alimentar 118

Anexo III - Protocolo de pesquisa 120

Anexo IV - Aprovação do comitê de ética 128

Anexo V - Artigo Nutrition Reviews enviado para publicação 129

CURRÍCULO LATTES 130 


\section{LISTA DE TABELAS E FIGURAS}

Tabela 1 - Prevalência de sarcopenia.

Figura 1 - Etiologia da sarcopenia

\section{Artigo 1}

Table 1 - Effect of protein intake on bone mass.

Table 2 - Effect of protein intake on muscle mass.

\section{Artigo 2}

Tabela 1 - Características gerais de mulheres com e sem sarcopenia.

Tabela 2 - Consumo de proteína e aminoácidos essenciais de mulheres com e sem sarcopenia.

Tabela 3 - Composição corporal e massa óssea segundo o consumo de proteína.

Figura 1 - Correlação entre o consumo de proteína, índice de massa muscular esquelética e densidade mineral óssea em mulheres idosas.

\section{Artigo 3}

Table 1 - Characteristic of elderly women.

Table 2 - Dietary intake and biochemical markers of bone metabolism in elderly women.

Table 3 - Body composition and bone mass according to levels of 25(OH)D and secondary hyperparathyroidism in elderly women.

Figure 1 - Prevalence of secondary hyperparathyroidism in women with and without sarcopenia. 


\section{LISTA DE ABREVIATURAS, SIGLAS E SIMBOLOS}

\begin{tabular}{|c|c|}
\hline $1,25(\mathrm{OH})_{2} \mathrm{D}_{3}$ & Cacitriol \\
\hline $25(\mathrm{OH}) \mathrm{D}_{3}$ & Calcidiol \\
\hline 4E-BP1 & Phosphorylated 4E-binding protein \\
\hline AI & Adequate intake \\
\hline ANOVA & Análise de variância \\
\hline ATP & Adenosina Trifosfato \\
\hline BCAA & Branch Chain Amino Acids \\
\hline $\mathrm{BMC}$ & Bone mineral content \\
\hline $\mathrm{BMD}$ & Bone mineral density \\
\hline BMI & Body mass index \\
\hline $\mathrm{CI}$ & Confidence interval \\
\hline DRIs & Dietary reference intake \\
\hline DXA & Dual energy $X$-ray absorptiometry \\
\hline EAA & Essential amino acids \\
\hline EAR & Estimated Average Requirement \\
\hline EUA & Estados Unidos da America \\
\hline FSP & Faculdade de Saúde Pública \\
\hline $\mathrm{g}$ & Grama \\
\hline $\mathrm{GH}$ & Growth hormone \\
\hline HPLC & Cromatografia Líquida de Alta Eficiência \\
\hline IDI & Instituto de diagnóstico por Imagem \\
\hline IGF-1 & Insulin-like-growth factor 1 \\
\hline $\mathrm{IMC}$ & Índice de massa corporal \\
\hline COEP & Comitê de Ética em Pesquisa \\
\hline IMMEa & Índice de massa muscular esquelética apendicular \\
\hline IU & International units \\
\hline kcal & Quilocaloria \\
\hline
\end{tabular}




\begin{tabular}{|c|c|}
\hline $\mathrm{kg}$ & Quilograma \\
\hline $\mathrm{L}$ & Litro \\
\hline $\mathrm{m}^{2}$ & Metro ao quadrado \\
\hline MAPK & Mitogen-activated protein kinase \\
\hline $\mathrm{mEq}$ & Miliequivalente \\
\hline $\mathrm{mg}$ & Miligrama \\
\hline $\mathrm{mL}$ & Militro \\
\hline MMEa & Massa muscular esquelética apendicular \\
\hline MRF & Myogenic regulatory factors \\
\hline mTOR & Mammalian target of rapamycin \\
\hline Myf5 & Protein family members of myogenic regulatory factors \\
\hline MyoD & Protein family members of myogenic regulatory factors \\
\hline $\mathrm{n}$ & Tamanho de amostra \\
\hline $\mathrm{NCC}$ & Nutrition Coordinating Center \\
\hline NDSR & Nutrition Data System for Research \\
\hline NEAP & Net endogenous acid production \\
\hline NHANES III & National Health and Nutrition Examination Survey \\
\hline nmoL & Nanomol \\
\hline OR & Odds ratio \\
\hline${ }^{\circ} \mathrm{C}$ & Graus celcius \\
\hline p70S6k & 70-kDa S6 protein kinase \\
\hline pg & Picograma \\
\hline $\mathrm{PKC}$ & Proteína quinase $C$ \\
\hline PRAL & Potencial renal acid load \\
\hline PTH & Paratormonio \\
\hline PTHi & Paratormônio intacto \\
\hline RDA & Recommended Dietary Allowance \\
\hline ROS & Reactive oxygen species \\
\hline rpm & Rotações por minuto \\
\hline RR & Risco relativo \\
\hline SPSS & Statistical Package for the Social Sciences \\
\hline
\end{tabular}


TH

UI

USP

VDR

VDREs

vs

WHO

$\%$

$<$

$>$

$\leq$

$\geq$

$\mu$
Terapia hormonal

Unidade internacional

Universidade de São Paulo

Receptor de vitamina D

Elementos resposta da vitamina D

Versus

World Health Organization

Porcentagem

Maior

Maior ou igual

Menor

Menor ou igual

Micro 


\section{APRESENTAÇÃO}

Esta tese inicia-se com a seção de introdução, seguida dos objetivos, metodologia, resultados, considerações finais, referências bibliográficas e, por fim, dos anexos. Na seção dos resultados, encontram-se três artigos, sendo o primeiro já submetido, o segundo e terceiro em vias de submissão à periódicos para publicação. O primeiro manuscrito é uma revisão da literatura e os dois últimos são compostos dos seguintes tópicos: resumo, introdução, metodologia, resultados, discussão, referencias bibliográficas e tabelas e gráficos. 


\section{INTRODUÇÃO}

\subsection{SARCOPENIA}

\subsubsection{Definição da sarcopenia}

O processo de envelhecimento envolve inúmeras mudanças da composição corporal que afetam a saúde, como a sarcopenia que tem grande relevância clínica e funcional (SAYER e col., 2008). Sarcopenia é uma palavra de origem grega que significa "perda de carne" $($ sarco = carne e penia = perda), e foi primeiramente descrito por Irwin Rosenberg ao observar o declínio da massa muscular com o decorrer da idade (ROSENBERG,1997). O estudo pioneiro sobre sarcopenia foi realizado por BAUMGARTNER e colaboradores (1998), que a definiram como a redução de massa muscular esquelética apendicular em dois desvios-padrão abaixo da média $\left(<5.45 \mathrm{~kg} / \mathrm{m}^{2}\right)$ de controles jovens e saudáveis pareados para a mesma etnia na população do Novo México.

\subsubsection{Epidemiologia da sarcopenia}

$\mathrm{Na}$ tabela 1, estão resumidas as prevalências de sarcopenia em diferentes populações. Em geral, observa-se grande variação de acordo com a idade (MELTON e col., 2000). Em média a prevalência em indivíduos com 60 anos é de 3-4\% e naqueles acima de 80 anos, varia de 10,9 a 50\%. No Brasil não existem dados na literatura que descrevam a prevalência de sarcopenia na população.

Os gastos aproximados com o tratamento de idosos acometidos pela sarcopenia são estimados a partir do efeito desta no aumento do risco de incapacidade física. Nos EUA, estima-se o gasto de 18,5 bilhões de dólares/ano dos quais 10,8 bilhões com homens e 7,7 bilhões com mulheres, o que representa $1,5 \%$ dos gastos totais com saúde no período de um ano (JANSSEN e col., 2004). 
Tabela 1: Prevalência de sarcopenia

\begin{tabular}{|c|c|c|c|}
\hline Autor e local & $\begin{array}{c}\text { Técnica de } \\
\text { Mensuração }\end{array}$ & Amostra & Prevalência \\
\hline $\begin{array}{l}\text { Baumgartner e col., } 1998 \\
\text { Novo México - EUA }\end{array}$ & DXA & $\begin{array}{l}\mathrm{H}-426 \\
\mathrm{M}-382\end{array}$ & $\begin{array}{l}\mathrm{H}\left\{\begin{array}{l}(70-74 \text { anos })-18,3-19,8 \% \\
>80 \text { anos }-57,6-52,6 \%\end{array}\right. \\
\mathrm{M}\left\{\begin{array}{l}(70-74 \text { anos })-24,1-23,1 \% \\
>80 \text { anos }-43,2-60,0 \%\end{array}\right.\end{array}$ \\
\hline $\begin{array}{l}\text { Melton e col., } 2000 . \\
\text { Rochester - EUA }\end{array}$ & DXA & $\begin{array}{l}\mathrm{H}-354 \\
\mathrm{M}-349\end{array}$ & $\begin{array}{l}\mathrm{H}\left\{\begin{array}{l}(70-79 \text { anos })-14 \% \\
>80 \text { anos }-42 \%\end{array}\right. \\
\mathrm{M}\left\{\begin{array}{l}(70-79 \text { anos })-9,8 \% \\
>80 \text { anos }-16,3 \%\end{array}\right.\end{array}$ \\
\hline $\begin{array}{l}\text { Iannuzzi-Sucich e col., } 2002 \\
\text { Connecticut-EUA }\end{array}$ & DXA & $\begin{array}{l}\mathrm{H}-142 \\
\mathrm{M}-195\end{array}$ & $\begin{array}{l}\mathrm{H}\{\geq 65 \text { anos }-26,8 \% \\
\mathrm{M}\{\geq 65 \text { anos }-22,6 \%\end{array}$ \\
\hline $\begin{array}{l}\text { Castillo e col.,2003 } \\
\text { San Diego -EUA }\end{array}$ & Bioimpedância & $\begin{array}{l}\text { H - } 694 \\
M-1006\end{array}$ & $\begin{array}{l}\mathrm{H}\left\{\begin{array}{l}(60-69 \text { anos })-4 \% \\
>85 \text { anos }-16 \%\end{array}\right. \\
\mathrm{M}\left\{\begin{array}{l}(60-69 \text { anos })-3 \% \\
>85 \text { anos }-13 \%\end{array}\right.\end{array}$ \\
\hline $\begin{array}{l}\text { Jassen e col., } 2002 \\
\text { NHANES III -EUA }\end{array}$ & Bioimpedância & $\begin{array}{l}\text { H - } 1079 \\
\text { M - } 1374\end{array}$ & 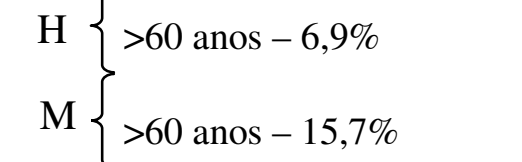 \\
\hline $\begin{array}{l}\text { Gillette-Guyonnet e col., } 2003 \\
\text { França }\end{array}$ & DXA & M - 7518 & $M\left\{\begin{array}{l}(76-80 \text { anos })-8,9 \% \\
(86-95 \text { anos })-10,9 \%\end{array}\right.$ \\
\hline $\begin{array}{l}\text { Sayer e col., } 2006 \\
\text { Inglaterra }\end{array}$ & $\begin{array}{l}\text { Relato de } \\
\text { quedas no } \\
\text { último ano } \\
\text { associado com } \\
\text { grip strengh }\end{array}$ & $\begin{array}{c}H-866 \\
M-1282\end{array}$ & $\begin{array}{l}\mathrm{H}\{>65 \text { anos }-14,3 \% \\
\mathrm{M}\{>65 \text { anos }-22,5 \%\end{array}$ \\
\hline $\begin{array}{l}\text { Lau e col., } 2005 . \\
\text { China }\end{array}$ & DXA & $\begin{array}{l}H-262 \\
M-265\end{array}$ & $\begin{array}{l}\mathrm{H}\{>70 \text { anos }-12,3 \% \\
\mathrm{M}\{>70 \text { anos }-7,6 \%\end{array}$ \\
\hline
\end{tabular}

H- homens, M- mulheres, DXA - Densitometria de dupla emissão de raios-X. 


\subsubsection{Fisiopatologia da sarcopenia.}

O músculo esquelético é constituído por feixes cilíndricos e paralelos de fibras e miofibrilas, compostas essencialmente por proteínas. As miofibrilas possuem unidades denominadas sarcômeros que constituem a unidade contrátil da fibra muscular. Cada sarcômero apresenta uma organização molecular constituída por filamentos finos e filamentos grossos. Os filamentos grossos são constituídos de macromoléculas de miosina e os filamentos finos, por moléculas de actina, tropomiosina e troponina. A contração muscular é promovida pelo deslizamento destes filamentos uns sobre os outros gerando, assim, a tensão muscular (MORLEY e col., 2001).

No entanto, para que haja a contração muscular, inicialmente é necessário um potencial elétrico. Os músculos são inervados por neurônios motores alfa, e todas as fibras musculares por ele inervadas são chamadas de unidades motoras. O recrutamento da unidade motora é componente básico do sistema locomotor, pois sinais dos diferentes centros do sistema nervoso central, como impulsos do sistema nervoso periférico conduzem à ativação dos músculos para que gerem o movimento. Quanto mais unidades motoras são estimuladas, maior é a força desenvolvida (DESCHENES, 2004).

As fibras musculares são classificadas em fibras de contração lenta (tipo I), inervadas por pequenos neurônios motores alfa de condução lenta, que emitem impulso contínuo para a manutenção do tônus muscular, e fibras de contração rápida (tipo II) que são inervadas por grandes neurônios motores alfa que emitem impulso descontínuo, tipicamente para desencadear uma atividade motora que exija força, velocidade ou potência (DESCHENES, 2004). Com o envelhecimento, ocorrem alterações estruturais, funcionais e metabólicas das fibras musculares e em suas unidades motoras (DOHERTY, 2003).

As fibras do tipo I parecem ser resistentes à atrofia, pelo menos até os 70 anos, enquanto a área relativa às fibras tipo II declina de 20 a 50\% com o passar dos anos (FRONTERA e col., 1991). No entanto, existe uma dissociação entre a redução do número de fibras e a massa muscular, uma vez que a atrofia é modesta quando comparada à redução na massa muscular, portanto a redução do número de fibras 
musculares parece também contribuir para o surgimento da sarcopenia. LEXELL e colaboradores (1992) estudando amostras do vasto lateral de cadáveres descreveram redução de $50 \%$ do número de fibras musculares após a nona década de vida, quando comparados aos jovens de 20 anos de idade.

A redução do número de fibras musculares pode ser explicada pelo processo neuropático crônico, caracterizado pela desmielinização dos neurônios motores alfa, cujo efeito é a diminuição da velocidade de transmissão eletrofisiológica do nervo, afetando assim a contração muscular (LAURETANI e col., 2006). Além disso, é caracterizado também pela denervação e reinervação progressiva, no qual há uma tentativa compensatória dos neurônios motores alfa restantes de ampliar seu território de atuação, aumentando suas unidades motoras e, em seguida, recrutando as fibras denervadas (EDSTROM e col 2007). Este processo neuropático crônico resulta em uma redução preferencial pelas fibras tipo II quando comparado com as fibras tipo I (McCOMAS, 1998). A perda das fibras musculares do tipo II representa diminuição das proteínas de cadeias pesadas de miosina, proporcionando redução no mecanismo de excitação e contração muscular das pontes transversais de actina e miosina (McCOMAS, 1998).

Além do processo neuropático crônico, outra hipótese que explica a diminuição do número de fibras musculares inclui alterações no metabolismo celular do músculo (ROLLAND e col., 2008). Grande parte da produção de energia para a função muscular ocorre por meio da fosforilação oxidativa mitocondrial. Quando há acúmulo do produto do metabolismo oxidativo, denominado espécie reativa de oxigênio (ERO), ocorrem alterações que podem danificar componentes celulares como as proteínas contráteis (actina e miosina) e a própria mitocôndria (HIONA e LEEUWENBURGH, 2008).

Essas alterações podem resultar na redução da taxa metabólica celular, com diminuição do transporte de elétrons, declínio da produção de ATP, comprometendo, assim, a respiração celular (AIKEN e col., 2002; BUA e col., 2002; WATERS e col., 2003). Além disso, ocorre redução da capacidade contrátil muscular pela inibição da atividade da ATPase, dependente de cálcio, do retículo sarcoplasmático, dificultando o acoplamento actina-miosina e indução da hiperpolarização do potencial de membrana (REID, 2001; FULLE e col., 2004). 
A capacidade de regeneração (diferenciação, maturação e desenvolvimento) do músculo esquelético também é afetada pelo envelhecimento. A regeneração do tecido muscular é controlada por diversos fatores de transcrição chamados de Myogenic regulatory factors (MRF). Uma vez ativados, estes fatores de transcrição serão responsáveis pela expressão fenotípica e controle da expressão gênica das proteínas miofibrilares. Quando ocorre injúria muscular, estes fatores promovem ativação, recrutamento e diferenciação de células tronco do músculo esquelético, denominadas células satélites, e novas miofibrilas e fibras maduras (CHARGÉ e RUDNICKI, 2004).

O processo de regeneração parece estar comprometido, primeiramente, pelo declínio do número de células satélites musculares, tanto em roedores como em seres humanos, especialmente das fibras tipo II (CONBOY e col., 2003; VERDIJK e col., 2007). Por outro lado, o declínio das células satélites com a idade, ainda, é controverso (DREYER e col., 2006). GALLEGLY e colaboradores (2004) acreditam que a deficiência de regeneração do tecido muscular também é influenciada pelos MRF, que modificam a proliferação e diferenciação celular e não, necessariamente, a redução do número de células satélites (GALLEGLY e col., 2004). A expressão dos fatores de determinação miogênica (MyoD), fator de regulação miogênica 5 (myd5) e a miogenina parecem estar diminuídos com a idade. A miostatina parece regular negativamente as células satélites, suprimindo a expressão de MyoD e miogenina proporcionando a redução da diferenciação e proliferação de miócitos (GALLEGLY e col., 2004; BIGOT e col., 2008; McCROSKERY e col., 2003).

O acúmulo dessas alterações no tecido muscular pode ainda estar associado à apoptose acelerada de miócitos e contribuir para a fisiopatogenia da sarcopenia (HERBST e col., 2007; DIRKS e col., 2007; MARZETTI e LEEUWENBURGH, 2006). Biópsias musculares em pessoas idosas mostraram aumento significativo de apoptose de miócitos quando comparados com indivíduos mais jovens (WHITMAN e col., 2005). A apoptose parece representar o fenômeno final entre a perda de massa muscular e todos os mecanismos descritos acima (DUPONT-VERSTEEGDEN e col., 2005). 


\subsubsection{Etiologia da sarcopenia}

A sarcopenia parece decorrer da interação complexa de inúmeros fatores como, por exemplo: diminuição da secreção de hormônios (hormônio do crescimento (GH), estradiol, testosterona), resistência à insulina, diminuição de fator de crescimento de insulina (IGF-1) e aumento de citocinas inflamatórias. Além disso, alguns aspectos de hábito de vida (tabagismo, atividade física (desuso), exposição solar) e fatores nutricionais como a deficiência de vitamina $\mathrm{D}$ e as alterações na ingestão proteica parecem contribuir para o surgimento da sarcopenia. (LANG e col., 2009).

Figura 1. Etiologia da sarcopenia

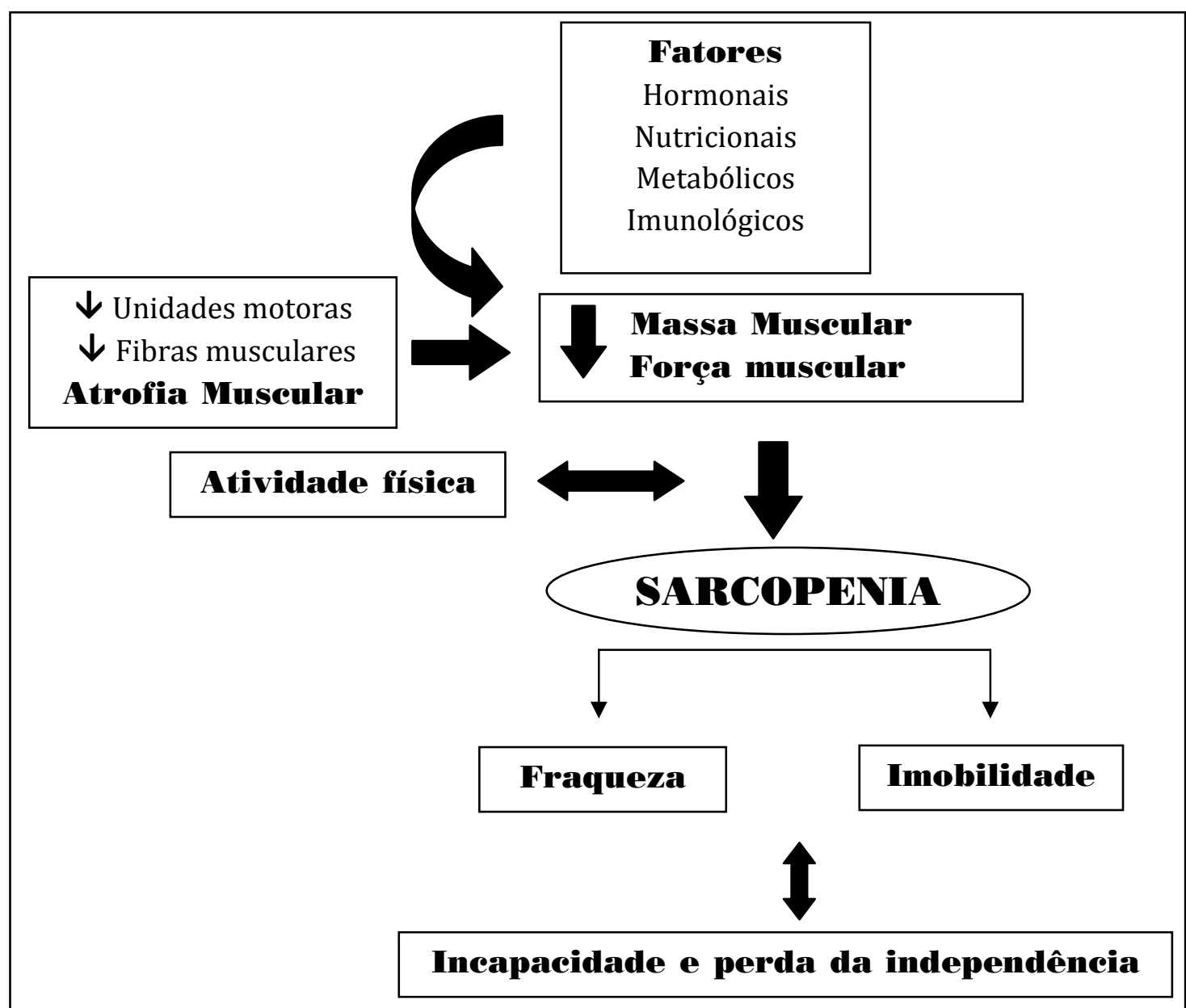

Adaptado de Doherty, 2003 


\subsubsection{Consumo de proteína}

O consumo de proteína está diretamente relacionado ao metabolismo proteico do músculo esquelético. Há evidências que o consumo inadequado pode contribuir para a perda de massa muscular (WALRAND e BOIRIE, 2005).

Um dos mecanismos pelos quais a proteína dietética poderia afetar o músculo esquelético é através da otimização da absorção de aminoácidos, promovendo estimulação e regulação da síntese proteica muscular (TIMMERMAN e VOLPI, 2008; VOLPI e col., 2003; DERRENS e RENNIE, 2003). Os aminoácidos essenciais, em particular, os de cadeia ramificada como a leucina, podem estimular a síntese proteica muscular em idosos (GARLICK, 2005).

A leucina parece ser o regulador chave da síntese proteica muscular e exerce os seus efeitos em nível pós-transcricional e, mais comumente, durante a fase de iniciação da tradução do RNA-mensageiro em proteína (ANTHONY e col., 2000a). O mecanismo pelo qual a leucina estimula a tradução de proteínas está relacionado ao fato do aumento da concentração intracelular desse aminoácido promover a ativação de uma proteína quinase denominada alvo da rapamicina em mamíferos (mTOR). O mTOR estimula a síntese proteica principalmente por meio de três proteínas regulatórias chaves: a proteína quinase ribossomal S6 de 70 kDA (p70S6k), a proteína 1 ligante do fator de iniciação eucariótico 4E (4E-BP1) e o fator de iniciação eucariótico 4G (ANTHONY e col., 2000b; ANTHONY e col., 2001; FUJITA e col., 2007). Estudos avaliando a ingestão de leucina em homens idosos observaram que o aumento da proporção deste aminoácido pode promover maior síntese de proteínas musculares (KATSANOS e col., 2006; PADDON-JONES e col., 2006).

De acordo com a avaliação do balanço nitrogenado, o Institute of Medicine (IOM) recomenda valores de ingestão protéica de $0,66 \mathrm{~g} / \mathrm{kg} /$ dia para EAR (Estimated Average Requirement) e 0,8g/kg/dia para RDA (Recommended Dietary Allowance). Ressalta-se, ainda, que o consumo deva ser acompanhado por uma oferta de energia proveniente da dieta entre 10-35\%, suficiente para obter adequada utilização de proteínas (STANDING COMMITTEE on the SCIENTIFIC EVALUATION of DRI, 2002). 
Em contrapartida, a atual recomendação do consumo de proteína parece ser insuficiente para compensar os efeitos negativos do envelhecimento sobre o metabolismo de proteína corporal (CAMPBELL e col., 2001; MORAIS e col., 2006; WOLFE e MILLER, 2008). CAMPEBELL e colaboradores (2001), avaliando a excreção de nitrogênio urinário e a espessura da área muscular da perna em 10 adultos e idosos com dieta normocalórica e com consumo de proteína de $0,8 \mathrm{~g} / \mathrm{kg} / \mathrm{dia}$, observaram diminuição da área muscular da perna $(-1,7$ cm e p=0,019) e da excreção urinária após 14 semanas de intervenção.

Estudos sugerem que a ingestão de proteínas moderadamente acima da recomendação $(1,0-1,3 \mathrm{~g} / \mathrm{kg} / \mathrm{dia})$ pode ser necessária para manter o equilíbrio de nitrogênio e aumentar a eficiência de síntese de proteína pelo músculo. (SYMONS e col., 2007; TIPTON e col., 2004; BOERSHEIM ecol., 2008). O aumento da ingestão proteica de $0,87 \mathrm{~g} / \mathrm{kg} /$ dia para $1,23 \mathrm{~g} / \mathrm{kg} /$ dia em mulheres (71-84 anos) com síndrome de fragilidade promoveu aumento significativo da massa muscular de 6,2\% (CHEVALIER e col., 2003). Estudo de base populacional também confirmou que o consumo de proteína está associado ao aumento de massa muscular no período de três anos. Os participantes que estavam no menor quintil de ingestão proteica $(0,8$ $\mathrm{g} / \mathrm{kg} / \mathrm{dia}$ ) tinham uma redução de $40 \%$ menos massa muscular se comparados aos que estavam no maior quintil (1,2 g/kg/dia) (HOUSTON e col., 2008).

Além da quantidade, a fonte de proteína também deve ser considerada, uma vez que existem diferenças no conteúdo de aminoácidos essenciais entre proteína vegetal e animal. Estudo avaliando a qualidade da proteína ingerida por mulheres idosas observou que a dieta com maior quantidade de proteína vegetal apresentava maior desequilíbrio no balanço da síntese proteica quando comparado com a dieta com maior quantidade de proteína animal (PANNEMANS e col., 1998). Lord e colaboradores (2007) estudaram a associação da qualidade da proteína com a massa muscular, verificaram que o consumo de proteína animal contribuía, independentemente de outros fatores, para o índice de massa muscular $\left(r^{2}=0,19\right.$; $\mathrm{p}=0,008)$ (LORD e col., 2007).

Por outro lado, estudo investigando o efeito da dose de proteína sobre o anabolismo de proteínas no músculo por meio de um alimento fonte de proteína e aminoácidos essenciais, foi demonstrado que $113 \mathrm{~g}$ de carne magra (30g de 
proteína e 220Kcal) foram suficientes para estimular a síntese proteica (SYMONS e col., 2009). Desta forma, PADDON-JONES e RASMUSSEM (2009) propuseram o consumo de 25-30 gramas de proteína de alta qualidade (aminoácidos essenciais) em cada refeição do dia com o objetivo de maximizar a síntese proteica muscular, particularmente em idosos.

\subsubsection{Vitamina D}

Classicamente, a vitamina D é conhecida por exercer suas ações em órgãosalvo, como intestino, rins, glândulas paratireóides e ossos. No entanto, durante as últimas duas décadas, relevante destaque tem sido dado ao papel em outros tecidos, incluindo o músculo esquelético. A identificação do receptor da vitamina D (VDR) em células musculares (ZANELLO e col., 1997; BISCHOFF e col., 2001) comprovou seu efeito direto sobre o tecido muscular, tanto por via genômica como por via não-genômica (CEGLIA, 2008).

Os efeitos genômicos seguem o mecanismo dos hormônios esteróides. No núcleo da célula ocorre a formação do complexo que consiste na ligação da forma ativa da vitamina $\mathrm{D}$, denominada $1,25(\mathrm{OH})_{2} \mathrm{D}_{3}$, a um receptor nuclear específico (VDR). Este complexo se liga ao receptor de ácido retinoico, formando heterodímeros que atuam nos elementos resposta da vitamina D (VDREs), iniciando assim, uma cascata de interações moleculares que resultam na modulação da transcrição de genes específicos (KIMBALL e col., 2008).

Os efeitos musculares não genômicos da vitamina $\mathrm{D}$ são rápidos, não dependentes de síntese proteica, e envolvem a ativação de um receptor de membrana, segundo mensageiros e a fosforilação de proteínas intracelulares. Até recentemente, não se conheciam os mediadores deste efeito e se acreditava que não dependessem da ligação com o VDR. No entanto, CAPIATI e colaboradores, em 2002, demonstraram que o tratamento com $1,25(\mathrm{OH})_{2} \mathrm{D}_{3}$ induziu à translocação do VDR para fração da membrana plasmática dos mioblastos, sugerindo que o VDR poderia ser este receptor de membrana e também o responsável pelos efeitos não-genômicos da $1,25(\mathrm{OH})_{2} \mathrm{D}_{3}$ (CEGLIA, 2008). 
A vitamina $\mathrm{D}$ parece ter função importante na contração muscular por meio da captação de cálcio celular. BOLLAND e colaboradores (1986) sugeriram que a $1,25(\mathrm{OH})_{2} \mathrm{D}_{3}$ seria a responsável por regular a captação de cálcio pelo tecido muscular, modulando a atividade das bombas de cálcio no retículo sarcoplasmático e também controlando o influxo de cálcio através dos canais de cálcio. Estudos em cultura de mioblastos demonstraram que a captação de cálcio é aumentada nas células expostas a níveis fisiológicos de $1,25(\mathrm{OH})_{2} \mathrm{D}_{3}$. Este efeito parece ser mediado pela ativação do VDR nuclear (ação genômica) e promove o aumento da síntese de proteínas como a calmodulina que regula a contração muscular, e a calbidina, uma proteína carreadora de cálcio (BOLLAND e col., 1983). Além disso, o efeito nãogenômico da vitamina D no músculo inclui a ativação da proteína quinase $\mathrm{C}$ (PKC) e a liberação de cálcio no citosol, responsáveis pelo transporte ativo no retículo sarcoplasmático, via enzima Cálcio-ATPase, aumentando o pool de cálcio (DRITTANTI e col., 1990; MARINISSEN, e col.,1994).

Outros efeitos da vitamina $\mathrm{D}$ no músculo esquelético são relacionados à proliferação e diferenciação de mioblastos (GIULIANI e BOLAND, 1984). Dados recentes indicam que a $1,25(\mathrm{OH})_{2} \mathrm{D}_{3}$ parece ativar rapidamente a via de sinalização não-genômica denominada mitogen-activated protein kinase (MAPK) resultando no início da miogênese, proliferação, diferenciação e apoptose celular (BUITRAGO e cols., 2006).

Estudos avaliando camundongos nos quais o gene do VDR foi eliminado (knock-out) encontraram desenvolvimento muscular anormal, caracterizado por fibras musculares $20 \%$ menores em seu diâmetro, redução no tamanho e peso corporal do animal e coordenação motora diminuída. Foi observada, ainda, elevada expressão gênica de marcadores da fase de diferenciação miogênica (fator de regulação miogênica 5, miogenina) (ENDO e col., 2003).

Mais recentemente, biópsias de tecido muscular de mulheres jovens e adultas submetidas à cirurgia ortopédica mostraram que a expressão do VDR diminuía com a idade (BISCHOFF-FERRARI e col., 2004a). Outro estudo analisando também biópsia muscular em adultos com deficiência de vitamina $\mathrm{D}$ mostrou predominante atrofia de fibras musculares do tipo II (SATO e col., 2002). Dessa forma, a vitamina D desempenha importante papel sobre a função muscular em idosos e pode estar 
associada com a diminuição da força muscular e, conseqüentemente, aumento da taxa de quedas (SNIJDER e col., 2006).

Estudos observacionais têm mostrado associação entre a concentração sérica de vitamina D e o desempenho físico. O estudo NHANES III observou que indivíduos com concentração sérica de $25(\mathrm{OH}) \mathrm{D}_{3}$ até $94 \mathrm{nmol} / \mathrm{L}$ eram capaz de andar e levantar de uma cadeira mais rapidamente do que indivíduos com concentrações de 25(OH) $\mathrm{D}_{3}$ inferiores a $60 \mathrm{nmol} / \mathrm{L}$ (BISCCHOFF-FERRARI e col., 2004b). O estudo prospectivo denominado Longitudinal Study of Aging Amsterdam, realizado ao longo de três anos, também demonstrou diminuição da força e da massa muscular em homens e mulheres idosos com concentração sérica de $25(\mathrm{OH}) \mathrm{D}_{3}$ menor $25 \mathrm{nmol} / \mathrm{L}$ (VISSER e col., 2003).

A suplementação de vitamina D promove benefícios sobre os parâmetros da função neuromuscular. PFEIFER e colaboradores (2000) comparando a suplementação de cálcio e vitamina D com a suplementação apenas de cálcio, durante 8 semanas em 148 mulheres idosas não institucionalizadas, relataram melhora do equilíbrio em $9 \%$ de mulheres idosas com concentração sérica de $25(\mathrm{OH}) \mathrm{D}_{3}$ inferiores a $50 \mathrm{nmol} / \mathrm{L}$ (PFEIFER e col., 2000). Em idosos institucionalizados, com concentração sérica de $25(\mathrm{OH}) \mathrm{D}_{3}$ inferiores a $50 \mathrm{nmol} / \mathrm{L}$, a suplementação de vitamina $\mathrm{D}$ por 12 semanas melhorou a função muscular em 4 a $11 \%$ dos pacientes (BISCHOFF e col., 2003). Da mesma forma, outro estudo placebo controlado avaliando 139 idosos com concentração de $25(\mathrm{OH})_{2} \mathrm{D}_{3}$ sérica inferior a $30 \mathrm{nmol} / \mathrm{L}$ e que receberam suplementação de 600.000 UI de ergocalciferol, verificou melhora significativa dos parâmetros de desempenho funcional e postural (DHESI e col., 2004).

Nos indivíduos idosos, o processo dinâmico de conservação do equilíbrio é diminuído, aumentando assim, a taxa de quedas. Vários estudos encontraram a relação entre a deficiência de vitamina $\mathrm{D}$ e o aumento da incidência de quedas entre idosos (FLICKER e col., 2005; BISCHOFF-FERRARI e col., 2005).

Em um ensaio randomizado, controlado, BISCHOFF e colaboradores, em 2003, mostraram que o tratamento com vitamina D e cálcio (800 UI e $1200 \mathrm{mg} / \mathrm{dia}$ ) durante três meses reduziu o risco de quedas em $49 \%$ quando comparado com a suplementação de cálcio apenas. Posteriormente, FLICKER e colaboradores (2005) 
verificaram o tratamento com vitamina D (inicialmente 10.000 UI por semana, em seguida, $1000 \mathrm{UI} /$ dia) e cálcio (600 mg/dia) por dois anos reduziu o risco de quedas em 30\% em relação a suplementação de apenas cálcio (FLICKER e col., 2005). Outra evidência do benefício da suplementação de vitamina D no músculo foi comprovada em uma meta-análise de cinco estudos prospectivos, duplo-cegos, randomizados e controlados que incluiam mais de 1200 indivíduos ambulatoriais e institucionalizados, mostrando que a suplementação de vitamina D diminuiu o risco de queda em 22\% (BISCHOFF-FERRARI e col., 2005).

\subsubsection{Conseqüências da sarcopenia}

A população mundial está envelhecendo. No Brasil, o aumento da população idosa segue a tendência mundial, passando de três milhões, em 1960, para sete milhões, em 1975, e 20 milhões em 2008, um aumento de aproximadamente 700\% em menos de 50 anos. A estimativa para 2025 é de um aumento de mais de 33 milhões, tornando o Brasil o sexto país com maior percentual populacional de idosos no mundo (VERAS, 2009).

Diversos autores demonstraram maior prevalência de incapacidade e dependência funcional em idosos, particularmente do sexo feminino (FISHER, 2004). Estes aspectos estão intimamente associados à redução da massa muscular decorrente do envelhecimento, mesmo em idosos bem sucedidos.

A sarcopenia é uma das variáveis utilizadas para definição da síndrome de fragilidade, que é altamente prevalente em idosos, conferindo maior risco para quedas, fraturas, incapacidade, dependência, hospitalização recorrente e mortalidade (TOPINKOVÁ, 2008).

Essa síndrome representa uma vulnerabilidade fisiológica relacionada à idade, resultado da deterioração da homeostase biológica e da capacidade do organismo de se adaptar às novas situações de estresse. A definição exata dos critérios da síndrome de fragilidade ainda é controversa. Entretanto, a sarcopenia e seu caráter reversível estão presentes na maioria das opiniões dos especialistas, o que significa dizer que estão diretamente relacionados ao desempenho musculoesquelético e ao potencial papel da reabilitação na restauração da capacidade física. Outros indicadores da 
síndrome de fragilidade incluem perda de peso recente, especialmente da massa magra; auto-relato de fadiga; quedas freqüentes; fraqueza muscular; diminuição da velocidade da caminhada e redução da atividade física, todos relacionados ao desempenho do sistema musculoesquelético (BAUER e col., 2008).

A avaliação do consumo alimentar e da vitamina D sérica em mulheres com sarcopenia ainda não esta estabelecida na literatura. Desta forma, a melhor compreensão desses fatores poderia contribuir para a implementação de estratégias de saúde pública de tratamento e prevenção da sarcopenia e minimizar seus efeitos deletérios, melhorando assim a qualidade de vida neste estágio da vida. 


\section{OBJETIVO}

\subsection{OBETIVO GERAL}

Investigar a relação entre sarcopenia, consumo alimentar e concentração sérica de vitamina $\mathrm{D}$ em mulheres idosas.

\subsection{OBJETIVOS ESPECÍFICOS}

- Artigo 1 - Revisar e discutir o efeito do consumo de proteína sobre a massa óssea e muscular;

- Artigo 2 - Avaliar o consumo de proteína em mulheres com diminuição de massa muscular e sua relação com a massa óssea e muscular;

- Artigo 3 - Estudar a relação entre a concentração sérica de vitamina D e o perfil bioquímico do metabolismo mineral ósseo e a massa muscular. 


\section{MÉTODOS}

\subsection{DELINEAMENTO DO ESTUDO}

Trata-se de um estudo observacional, transversal.

\subsection{POPULAÇÃO DO ESTUDO}

Foram recrutadas mulheres com idade igual ou superior a 65 anos no período de fevereiro de 2007 a dezembro de 2008. O recrutamento foi realizado por meio de telefonemas realizados pela pesquisadora para as pacientes cadastradas no banco de dados do serviço de densitometria óssea do Hospital São Paulo, Disciplina de Reumatologia da Universidade Federal de São Paulo e residentes na área metropolitana de São Paulo que realizavam densitometria óssea no Instituto de diagnóstico por Imagem (IDI).

\subsubsection{Cálculo do tamanho amostral.}

Considerando a prevalência de sarcopenia entre 3,0\% (Castillo e col., 2003) e 22,6\% (Iannuzzi-Sucich e col., 2002) em mulheres acima de 60-65 anos, ou em média 12,8\%, o cálculo do tamanho amostral foi realizado segundo LEVINE, 2000 e é dado por:

$$
\mathrm{n}=\frac{\left(\mathrm{Z}_{\alpha / 2}\right)^{2} \cdot \mathrm{p} \cdot \mathrm{q}}{\mathrm{E}^{2}}
$$

em que :

$\mathrm{n}=$ Número de indivíduos na amostra

$\mathrm{Z}_{\alpha / 2}=$ Valor crítico que corresponde ao grau de confiança desejado $95 \%$.

$\mathrm{p}=$ Proporção populacional de indivíduos pertencentes à categoria que nos interessa estudar $(12,8 \%)$. 
$\mathrm{q}$ = Proporção populacional de indivíduos que não pertence à categoria que nos interessa estudar $(q=1-p)$.

$\mathrm{E}=$ Margem de erro ou erro máximo de estimativa. Identifica a diferença máxima entre a proporção amostral e a verdadeira proporção populacional $(0,05)$.

O valor obtido pela fórmula foi de 172 mulheres, no entanto, consideramos a perda amostral aproximadamente de 15\%. Sendo assim, foram avaliadas 200 mulheres acima de 65 anos, 35 mulheres com sarcopenia e 165 sem sarcopenia.

\subsubsection{Critérios de exclusão}

Os critérios de exclusão adotados foram:

- Mulheres que necessitam de auxílio para locomoção;

- Idosas institucionalizadas ou hospitalizadas;

- Doença neuromuscular primária conhecida;

- Qualquer tipo de câncer e mielomas;

- Insuficiência renal (creatinina sérica $>1,2 \mathrm{mg} / \mathrm{dL}$ ), hepática ou pulmonar;

- Doença cerebrovascular;

- Déficit cognitivo que as impossibilitassem de fornecer respostas, tais como sequielas neurológicas ou demências senis;

\subsection{PROTOCOLO DE ESTUDO}

As mulheres foram avaliadas após explicação do projeto e assinatura do termo de consentimento (Anexo I), conforme preconiza a resolução no. 196 do Conselho Nacional de Saúde, de 10 de outubro de 1996.

O estudo constou das avaliações de densitometria óssea, composição corporal, fraturas, bioquímica e ingestão alimentar (Anexo II). Além disso, foram entrevistadas quanto à história clínica, capacidade funcional e atividade física. $\mathrm{O}$ resultado foi anotado em protocolo de atendimento elaborado para esta coleta de dados (Anexo III). 


\subsubsection{Avaliação da Densidade Óssea}

O estudo da densidade mineral óssea para avaliação da presença de osteoporose foi realizado pelo densitômetro de dupla emissão com fonte de raios-X (GE-Lunar, modelo DPX-MD plus, WI, USA).

O exame foi realizado na coluna lombar, fêmur proximal (trocânter, colo de fêmur e fêmur total). O procedimento técnico padrão foi adotado no posicionamento das pacientes para a realização do exame com controle de qualidade diário (BRANDÃO e col., 2009). Foram utilizados os dados de referência do NHANES III (LOOKER e col., 1998). Utilizou-se o modo médio (medium scan mode) e a análise foi feita com o programa Lunar versão 8,5. A avaliação da densidade do fêmur direito foi realizada pelo método manual, com rotação interna do quadril utilizando um posicionador desenvolvido pelo serviço. O coeficiente de variação do método adotado pelo serviço é de 3,0\% para o fêmur e de 2,0\% para a coluna e 0,6 para o corpo total (SZEJNFELD e col., 1995). O critério de diagnóstico utilizado para osteoporose foi o proposto pela (WHO, 1994).

\subsubsection{Avaliação da Composição Corporal}

Para o estudo da composição corporal foi utilizado o densitômetro de dupla emissão com fonte de raio-X (Lunar Radiation Corporation, modelo DPX, Madison, WI, USA). Foram avaliados massa muscular total, massa muscular esquelética, massa adiposa, densidade óssea do corpo total e conteúdo mineral ósseo do corpo total.

Para diagnóstico de sarcopenia foi utilizado a definição de BAUMGARTNER e col., 1998 que se baseia na mensuração da massa muscular esquelética apendicular (MMEa). O índice de massa muscular esquelética (IMME) foi calculado a partir da determinação de massa muscular esquelética apendicular (massa muscular das pernas e dos braços) em quilos do indivíduo dividido pelo quadrado da estatura em metros, ou seja: $\mathrm{IMMEa}=$ massa muscular esquelética dos Braços + Pernas $(\mathrm{kg}) /$ Altura $^{2}(\mathrm{~m})$, sendo considerada sarcopenia quando a massa muscular esquelética apendicular fosse menor ou igual a dois desvios-padrão da população feminina de referência. Isto 
é, quando o valor encontrado estivesse abaixo de $5,45 \mathrm{~kg} / \mathrm{m}^{2}$ (BAUMGARTNER e col., 1998). A população de referência utilizada por Baumgartner foi um estudo de Rosetta que avaliou 284 mulheres saudáveis com idade entre 18-40 anos (GALLAGHER e col, 1997).

\subsubsection{Avaliação de força}

O dinamômetro de força de preensão palmar da marca Jamar® foi utilizado para determinar a força muscular. Para a realização das mensurações, os indivíduos foram posicionados sentados com o braço aduzido paralelo ao tronco, cotovelo fletido a 90 graus e antebraço e punho em posição neutra. Foram realizadas três medições com intervalo mínimo de um minuto entre elas no lado dominante. A média dos três valores foi registrada (Harkonen e col., 1993).

\subsubsection{Avaliação radiográfica}

A avaliação radiológica das vértebras foi realizada por meio do estudo das colunas dorsal e lombar (T4 a L4) na posição em perfil de todas as pacientes. Para o protocolo de aquisição da imagem pela radiologia convencional da coluna vertebral, os seguintes critérios foram utilizados: distância do tubo-filme de $120 \mathrm{~cm}$, com feixe de raios $\mathrm{X}$ torácico centrado em T8 e filme lombar centrado em L3. Os critérios propostos por GENANT e colaboradores (1993) foram utilizados para classificar o tipo e a gravidade da deformidade vertebral. As fraturas apendiculares foram anotadas a partir de dados da história clínica que constam no prontuário médico e confirmadas durante a entrevista.

\subsubsection{Avaliação laboratorial do metabolismo ósseo e mineral}

Durante o período de coleta de dados pessoas treinadas e capacitadas, colheram pela manhã, após jejum de oito horas, amostras de $20 \mathrm{ml}$ de sangue venoso, utilizando materiais descartáveis. 
Após a coleta, as amostras foram centrifugadas a $2000 \mathrm{rpm}$ por 10 minutos em temperatura ambiente. Os soros foram armazenados no freezer $-80^{\circ} \mathrm{C}$ para posterior análise de cálcio total, fósforo, potássio, creatinina, albumina, paratormônio intacto, calcidiol, proteína $\mathrm{C}$ reativa.

As análises laboratoriais de cálcio total, fósforo, potássio, creatinina, albumina e proteína $\mathrm{C}$ reativa foram realizadas pelo Laboratório Central do Hospital São Paulo. A análise do PTH intacto foi realizada pelo Laboratório CRIESP e pelo Laboratório CURA Imagem e Diagnóstico e do calcidiol, no laboratório Vitae Análises Clínicas.

Os valores de referência para cálcio total, fósforo, potássio, creatinina, albumina, paratormônio intacto, proteína $\mathrm{C}$ reativa foram os adotados pelos laboratórios onde a análise foi realizada. Para o calcidiol, foram adotados os valores propostos por HOLICK (2009).

- Cálcio total - método colorimétrico. Valores normais: 8,0 a 10,5 mg/dL.

- Fósforo - método colorimétrico. Valores normais: 2,5 a 4,5 mg/dL.

- Potássio - eletrodo íon-seletivo. Valores normais: 3,5 a 5,0 mmol/L

- Creatinina - método cinético colorimétrico. Valores normais: 0,6 a 1,2 mg/dL.

- Albumina - método colorimétrico. Valores normais: 3,2 - 5,6 g/dL.

- Paratormônio intacto (PTH) - método de quimio imunoluminescência.Valores normais: 6-65 pg/mL.

- Calcidiol 25(OH) $\mathrm{D}_{3}$ - método de Cromatografia Líquida de Alta Eficiência (HPLC). Valores referência: desejáveis acima de $75 \mathrm{nmol} / \mathrm{L}(>30 \mathrm{ng} / \mathrm{mL})$, insuficiência de vitamina $D$ entre 51-74 nmol/L (entre 21-29 ng/mL), deficiência de vitamina D abaixo $50 \mathrm{nmol} / \mathrm{L}$ (abaixo $20 \mathrm{ng} / \mathrm{mL}$ ).

\subsubsection{Avaliação do consumo alimentar}

Para avaliar o consumo alimentar foi utilizado o registro alimentar de três dias, no qual a paciente anotou todos os alimentos e bebidas consumidos ao longo de três dias dos quais dois eram dias úteis (dias alternados) e um dia do final de semana (sábado ou domingo). 
O uso do método de registro alimentar do consumo alimentar teve como objetivo avaliar a ingestão média de energia (kcal), carboidrato $(\mathrm{g})$, proteína $(\mathrm{g})$, aminoácidos essenciais, gordura $(\mathrm{g})$, cálcio $(\mathrm{mg})$, fósforo $(\mathrm{mg})$, potássio $(\mathrm{mg})$, magnésio $(\mathrm{mg})$, vitamina $\mathrm{D}(\mu \mathrm{g})$. Este método foi escolhido porque o registro alimentar de três dias reflete com maior confiabilidade a ingestão de micronutrientes. Além disto, há a vantagem do método não depender da memória, uma vez que, o registro deve ser realizado logo após a ingestão dos alimentos e bebidas (FISBERG e col., 2005). Os dados obtidos pelo registro alimentar de três dias foram calculados utilizando o programa NDSR - Nutrition Data System for Research - Universidade de Minnessota, 2007.

Para avaliação da adequação do consumo de proteína foi utilizado o método EAR (estimate average requirement) como ponto de corte que verifica a proporção de indivíduos cuja ingestão do nutriente está inadequada, proposto pelo Institute of Medicine - DRI 2002. Esse número corresponde à área da curva abaixo desse valor de referência.

Além disso, para controlar o efeito do consumo de energia proveniente da dieta nos micronutrientes avaliados foi aplicado o método do nutriente residual, proposto por WILLET e STAMPER (1998). Foram consideradas apenas as pacientes com ingestão calórica entre 500 e 3500 kcal/dia (WILLET e STAMPER, 1998).

O cálculo da estimativa de carga ácida proveniente da dieta, foi feito de acordo com FRANSSETTO e col., 2007 que determina NEAP (net endogenous acid production) e PRAL (potencial renal acid load), segundo as fórmulas abaixo:

$\operatorname{NEAP}(\mathrm{mEq} /$ dia $)=[54,5 \mathrm{x}$ proteína $(\mathrm{g} / \mathrm{dia}) /$ potássio $(\mathrm{mEq} / \mathrm{dia})]-10,2$

PRAL $(\mathrm{mEq} / \mathrm{dia})=0,49 \mathrm{x}$ proteína $(\mathrm{g} / \mathrm{dia})+0,037 \mathrm{x}$ fósforo $(\mathrm{mg} / \mathrm{dia})-0,021 \mathrm{x}$ potássio (mg/dia) - 0,026 x magnésio $(\mathrm{mg} /$ dia $)$ - 0,013 x cálcio $(\mathrm{mg} / \mathrm{dia})$

\subsubsection{História clínica}

$\mathrm{Na}$ avaliação da história clínica, perguntou-se sobre a idade da menarca e a idade da última menstruação, uso da terapia de reposição hormonal (TRH), quedas 
durante o último ano, história familiar de fratura, fratura prévia, hábito de fumar, medicação em uso atual e uso de suplemento de cálcio e vitamina D e comorbidades.

\subsubsection{Avaliação da capacidade funcional}

A capacidade funcional foi avaliada por meio de dois questionários de Atividades Básicas da Vida Diária (AVD) (KATZ e col., 1970) e Atividades Instrumentais da Vida Diária (AIVD) (LAWTON e col., 1992).

A capacidade funcional avalia as atividades passíveis de desenvolvimento em uma pessoa, tendo em vista a sua capacidade funcional. As atividades básicas da vida diárias (ADV) e as atividades instrumentais da vida diária (AIVD) são aquelas necessárias ao cuidado pessoal, tais como: banhar-se, alimentar-se, vestir-se, deitarse e levantar-se da cama, movimentar-se em casa, usar o telefone, fazer as compras, cuidar das próprias finanças, arrumar a casa e fazer pequenos trabalhos manuais. A execução destas tarefas depende da habilidade física e cognitiva do indivíduo.

As escalas de avaliação destes questionários sintetizam, por meio de um índice, o grau de independência do indivíduo na realização de tais atividades e, indiretamente, o estado de saúde e a necessidade de auxílio, usualmente verificados em pacientes idosos.

\subsubsection{Atividade Física}

Os indicadores de atividade física envolveram quatro domínios (lazer, trabalho, deslocamento para o trabalho e atividades domésticas). A partir das respostas dadas pelos entrevistados a estas questões, as pacientes foram classificadas como ativas, e sedentárias. As pacientes ativas foram as que informaram praticar exercício físico ou esporte de intensidade moderada por pelo menos 30 minutos diários em cinco ou mais dias da semana; ou exercício físico ou esporte de intensidade vigorosa por pelo menos 20 minutos diários em pelo menos três dias por semana e/ou realizar atividades domésticas (WHO, 2004).

As pacientes sedentárias foram aqueles que informaram não fazer exercícios físicos ou esportes, não andar freqüentemente a pé e não carregar freqüentemente 
carga pesada no seu trabalho (ou não trabalharam nos últimos três meses), não se deslocar de casa para o trabalho a pé ou de bicicleta, não ser responsável pela limpeza pesada de suas residências (PATÉ e col., 1995).

\subsection{ANÁLISE ESTATÍSTICA}

A análise descritiva dos dados foi realizada inicialmente com o intuito de conhecer as características gerais da população: média e desvios-padrão.

A distribuição normal foi verificada por meio do teste Kolmogorov-Smirnov. Para as variáveis com distribuição normal foi aplicado o teste t-student para comparação de médias (duas), enquanto a correlação de Pearson foi aplicada para verificar a associação entre as variáveis do estudo. O teste Qui-quadrado ou teste exato de Fisher (quando caselas apresentarem $n<5$ ) foi utilizado para comparações de prevalências entre os grupos. Entretanto, quando as variáveis não apresentavam distribuição normal foram utilizado testes não paramétricos (Mann-Whitney, correlação de Spearman). Ao avaliar a diferença de média da vitamina D sérica entre os grupos, levou-se em consideração o ajuste para as estações do ano, uma vez que há diferença na irradiação solar durante o ano.

Os dados do presente estudo serão avaliados com o auxílio do programa de computador Statistical Package for the Social Sciences (SPSS), versão 12.0. O valor de significância considerado foi de $5 \%$, ou seja, $\mathrm{p}<0,05$.

\subsection{ASPECTOS ÉTICOS}

Este trabalho foi aprovado pelo Comitê de Ética em Pesquisa (COEP) da Faculdade de Saúde Pública da Universidade de São Paulo de acordo com as diretrizes e normas que regulamentam as pesquisas envolvendo seres humanos, aprovadas pela Resolução no. 196, de 10 de outubro de 1996, do Conselho Nacional de Saúde. Protocolo de pesquisa n. 1658 (anexo IV) 


\section{RESULTADOS}

Artigo 1:

"Protein intake and its effect on bone and muscle mass in the elderly"

Artigo original

Submetido à Nutrition Reviews (Anexo X) 


\section{PROTEIN INTAKE AND ITS EFFECT ON BONE AND MUSCLE MASS IN THE ELDERLY}

Patrícia de Souza Genaro, MS and Lígia Araújo Martini, PhD

Nutrition Department, School of Public Health, University of São Paulo, SP Brazil

Address correspondence and reprint request to Lígia A. Martini, PhD

Nutrition Department, School of Public Health, University of São Paulo

Av Dr Arnaldo, 715. São Paulo, SP, Brazil - 01246904

Email: $\underline{\text { lmartini@usp.br }}$

Article type: Special Article

Running title: Protein intake in the elderly

Word counts: Abstract: 116 Body text: 5102 Figures: 2 References: 59

Key words: Protein intake, bone mass, muscle mass, elderly 


\begin{abstract}
The aging process frequently is characterized by an involuntary loss of muscle (sarcopenia) and bone (osteoporosis) mass. Both chronic diseases are associated with decreased metabolic rate, increased risk of falls/fracture, and, as a result, increased morbidity and loss of independence in the elderly. Quality and quantity of protein intake affects bone and muscle mass in several ways and there is evidence that increased essential amino acid or protein availability can enhance muscle protein synthesis and anabolism, as well improve bone homeostasis in older subjects. Though evaluate renal function is important since its decrease with ageing. Finally protein and calcium intake should be considered for the prevention or treatment of the chronic diseases as osteoporosis and sarcopenia.
\end{abstract}




\section{INTRODUCTION}

The aging process is characterized by an involuntary loss of muscle (sarcopenia) and bone (osteoporosis) mass. This degenerative loss of skeletal muscle occurs at a rate of 3-8\% per decade after the age of 30 and accelerates with advancing age (1). Also there is evidence that bone loss starts in the third and fourth decade of life, and in women, the annual rates of bone loss increases above $1 \%$ after menopausal period (2). Lifetime risk of any osteoporotic fracture is very high with ranges of $40-50 \%$ in women and $13-22 \%$ for men (3). Sarcopenia and osteoporosis are associated with decreased metabolic rate, increased risk of falls and fracture and, as a result, increased morbidity and loss of independence (4).

The main amino acid reservoir in the body is skeletal muscle, which contains $50-75 \%$ of all proteins in the human body (5). In addition, loss of skeletal muscle and protein intake are closely related and play an important role in both chronic diseases since it affects both muscle anabolism and bone metabolism (6).

Based on the results of all available studies that have estimated the minimum protein intake necessary to avoid a progressive loss of lean body mass determined by nitrogen $(\mathrm{N})$ balance, the Food and Nutrition Board recommends a protein intake to be administered in normal conditions of at $0.6 \mathrm{~g} / \mathrm{kg}$ per day for Estimated Average Requirements (EAR) and $0.8 \mathrm{~g} / \mathrm{kg}$ per day for Recommended Dietary Allowance (RDA). It is emphasized that intake must be accompanied by an adequate energy supply to achieve optimal protein utilization and it should account for 10-35\% of total energy consumed (7).

Campbell et al (2008) assessed the effect of age on the EAR and RDA for protein and observed that the mean protein requirement was not different between the younger $(0.61 \mathrm{~g}$ protein $/ \mathrm{kg} / \mathrm{d})$ compared with older subjects $(0.58 \mathrm{~g}$ protein $/ \mathrm{kg} / \mathrm{d})$ suggesting that the requirement for total dietary protein is not different for healthy older adults than for younger adults and that the allowance estimate does not differ statistically from the RDA (8).

On the other hand, EAR and RDA could be greater than the assumed in malnourished or elderly ill subjects and protein turnover value per kilogram of body weight might be higher as a result of a hyper-catabolic state when compared to 
elderly healthy persons (9). Additionally, consume less than the EAR have been observed in elderly Americans. The NHANES III observed that the percentage of men between 51-70 years old who consumed less than the EAR for protein was less than $3 \%$ and $5.6 \%$ for men above 71 years old. In women between 51-70 years old $4.4 \%$ and above 71 years old $5.9 \%$ consumed protein less than EAR (10).

Protein intake seems to be very important to provide some benefit in managing chronic diseases such as osteoporosis and sarcopenia and this review intends to discuss the effect of protein intake on muscle and bone mass and provide an overview of the current status of research in these areas.

\section{POTENCIAL ROLE OF PROTEIN INTAKE ON BONE AND MUSCLE} MASS

There are several potential mechanisms by which protein intake affects bone metabolism. It is observed that increase protein intake might improve bone matrix collagen protein (11). One third of bone volume is composed of $50 \%$ of protein, which is critical for the synthesis of type I collagen that involves post translational modifications of amino acids, including hydroxylation of lysine and proline, and many other non-collagen proteins in the bone matrix (12).

A potential effect of protein intake on bone mass involves the production and action of Insulin Like Growth Factor (IGF-1) (13). It is an essential factor for longitudinal bone growth and induces an anabolic effect on bone mass during adulthood. It also has pluripotent effects on calcium and phosphate metabolism, including enhanced calcitriol synthesis and stimulated renal phosphate reabsorption. IGF-1 selectively stimulates the plasma membrane uptake of inorganic phosphate in osteoblastic cell lines to promote matrix mineralization (13). In an experimental study with protein-restricted adult female rats, a marked decrease of $29-34 \%$ in plasma IGF-I was shown, trabecular BMD was decreased and accompanied by an increased urinary deoxypyridinoline excretion without any change in osteocalcin levels, suggesting an uncoupling between resorption and formation (14). In humans practicing calorie restriction with reduced protein intake from an average of $1.67 \mathrm{~g} / \mathrm{kg}$ of body weight per day to $0.95 \mathrm{~g} / \mathrm{kg}$ of body weight per day for 3 weeks it was 
observed a reduction in serum IGF-1 from $194 \mathrm{ng} / \mathrm{mL}$ to $152 \mathrm{ng} / \mathrm{mL}$. In addition, undernourished elderly with hip fracture, protein supplementation of $20 \mathrm{~g} / \mathrm{d}$ could increase IGF-1 production and attenuation of proximal femur bone loss (15).

Protein intake, especially amino acids as leucine, and IGF-1 are anabolic stimuli for muscle metabolism. Evidences suggest that amino acid availability is a potent regulator of muscle protein synthesis and its increased can enhance muscle protein synthesis and anabolism in older subjects (16). Both anabolic stimuli for muscle share a common pathway of action via activation of mammalian target of rapamycin (mTOR) signaling cascade (17). Stimulation of muscle protein synthesis in humans after feeding is accompanied by enhanced phosphorylation and activity of the mTOR signaling pathway, including the $70-\mathrm{kDa}$ ribosomal protein S6 kinase (S6K1) and its target ribosomal protein S6 (rpS6). In addition, global rates of protein synthesis are tightly regulated by the activity of the guanine nucleotide exchange factor eukaryotic initiation factor $2 \mathrm{~B}$ (eIF2B), which is responsive to amino acids intake and is under the control of glycogen synthase kinase-3b (17).

\section{EFFECT OF DIETARY PROTEIN ON BONE MASS}

\section{Effect of quantity of protein intake on bone mass}

Recent evidence supports the hypothesis that dietary protein is also critical for bone health and fracture reduction, and quantity of protein intake may be important for preserving bone mass in later years. Epidemiological studies have observed that quantity of protein has influence on bone metabolism and BMD (18-21). The Framingham Osteoporosis Study was carried out on a large cohort of elderly women and men, prospectively followed over 4 years. It was observed that in the highest protein intake (84-152g/day) there was protection against spinal and femoral bone loss in both genders when compared to the lowest quartile (17-51g/day) (18). Also dietary protein more than $75 \mathrm{~g} /$ day and total BMD for the hip were positively associated in post-menopausal women in the Third National Health and Nutrition Examination Survey (19). Similarly, in a prospective study of approximately 40,000 women in Iowa, higher protein intakes were associated with a $69 \%$ reduction in risk of hip fracture (20). In addition, a case-control study of 2500 men and women in 
Utah demonstrated a negative relationship between protein intake and hip fracture incidence in men and women between the ages of 50 and 69. In the highest quartile of protein intake (17.4-30.8\% of energy intake), hip fracture incidence was reduced by $65 \%(21)$.

Protein intake also has an effect on calcium balance. Previous studies observed a decrease in renal tubular reabsorption of calcium and an increase in urinary calcium excretion with high protein intake. It was assumed that the additional calcium loss is entirely from bone, leading to the hypothesis that high protein diets are detrimental to the skeleton $(22,23)$.

However recent studies evaluating a moderate increase in dietary protein, from $10 \%$ to $20 \%$ and calcium balance through calcium isotopes observed that the increase in urinary calcium excretion is due to improved intestinal calcium absorption, improving bone health by decreased urinary deoxypyridinoline and increased serum insulin-like growth factor I without affecting parathyroid hormone, osteocalcin, bone-specific alkaline phosphatase, or tartrate-resistant acid phosphatase and did not result in negative skeletal calcium balance (24). Also another study evaluating high levels of protein intake $(2.1 \mathrm{~g} / \mathrm{kg} / \mathrm{d})$ and calcium balance by stable calcium isotopes observed that intestinal calcium absorption increased during the high-protein diet in comparison with the moderate $(26.2 \mathrm{vs} .18 .5 \%, \mathrm{p}<0.0001)$ as did urinary calcium $(5.23$ vs. $3.57 \mathrm{mmoL} / \mathrm{d}, \mathrm{p}<0.0001)$. The high-protein diet caused a significant reduction in the fraction of urinary calcium of bone origin and a non significant trend toward a reduction in the rate of bone turnover. There were no protein-induced effects on net bone balance (25). These data directly demonstrate that, at least in the short term, high-protein diets are not detrimental to bone health.

The negative effect of high protein intake that usually is observed in some studies might be addressed to the low calcium intake and not necessarily to high protein intake. The Nurse's Health Study, a cohort of 85,900 women aged 35-59 years. During 12 years of follow-up, protein intake more than $90 \mathrm{~g} / \mathrm{d}$ was associated with an increased risk of forearm fracture $(\mathrm{OR}=1.22$, 95\%CI 1.04-1.43). However women with high protein ( $>90 \mathrm{~g} /$ day) diets that were also high in calcium had a relative risk of 1.15 (95\%CI 0.84-1.58) for forearm fracture while a more elevated risk of 1.31 (95\% CI 0.94-1.82) was observed among women with high protein but 
low calcium $(\leq 541 \mathrm{mg} /$ day $)$ diets, which suggests that risk of forearm fracture with higher intakes of protein may be exacerbated by a low calcium intake (26). Also, in the epidemiologic study E3N (Etude Epidémiologique de femmes de la Mutuelle Générale de l'Education Nationale) with 2408 women who reported a fracture it was observed that women who had high protein intake and was in the lowest quartile of calcium $(<400 \mathrm{mg} / 1000 \mathrm{kcal})$ was associated with a significant increased in fracture risk (RR 1.51 for highest versus lowest quartile; 95\%CI,1.17-1.94) (27). Similarly, Meyer et al (28) observed that subjects with the combination of high protein intake (20.6g/d, highest quartile bound) and low calcium intake $(435 \mathrm{mg} / \mathrm{d}$, lowest quartile bound) were at approximately double the risk of hip fracture (RR 1.96, CI 95\% 1.093.56) compared with other subjects in the study. These studies suggest that the calcium intake may in fact influence the impact of dietary protein on the skeleton.

\section{Effect of quality of protein intake on bone mass}

Also protein sources may exhibit different effects on bone metabolism and BMD. Studies have observed that animal protein intake (meat and dairy products) is associated with higher BMD and also a better effect on bone and calcium metabolism, while vegetable protein intake (soy food) has been linked with no effect on BMD.

In a community-dwelling cohort of 572 women and 388 men aged 55-92 years, multiple linear regression analyses adjusted for standard osteoporosis covariates showed a positive association with animal protein consumption. For every $15 \mathrm{~g} /$ day increase in animal protein intake, BMD increased by $0.016 \mathrm{~g} / \mathrm{cm}^{2}$ at the hip $(\mathrm{p}=0.005), 0.012 \mathrm{~g} / \mathrm{cm}^{2}$ at the femoral neck $(\mathrm{p}=0.02), 0.015 \mathrm{~g} / \mathrm{cm}^{2}$ at the spine $(\mathrm{p}=0.08)$, and $0.010 \mathrm{~g} / \mathrm{cm}^{2}$ for the total body $(\mathrm{p}=0.04)$. Conversely, a negative association between vegetable protein and BMD was observed in both sexes (29). Larsson et al observed that the consumption of red meat $(\mathrm{p}=0.05)$ and fish and seafood ( $\mathrm{p}=0.07)$ was modestly positively associated with IGF-I concentrations (30). In a randomized study with healthy postmenopausal women, it was observed that consuming a high-meat diet $(117 \mathrm{~g}$ of protein per day or $1.62 \mathrm{~g} / \mathrm{kg} / \mathrm{d})$ did not affect calcium excretion and biochemical markers of bone formation and resorption when compared with a low-meat diet (45g/d of meat and $68 \mathrm{~g}$ of protein) (31). 
Investigating the differences between animal and vegetable protein intake in BMD, a community-based study observed that hip bone mineral density of 76 vegetarian Chinese women (age 70-89y) was lower when compared to omnivorous control subjects (32). Furthermore, in a 9-month intervention with sixty-one postmenopausal, soy protein intake showed no impact on bone mineral density (33). Similarly a randomized, double-blind, placebo controlled clinical trial in 131 healthy ambulatory women aged 60 years old were randomly assigned into 1 of 4 intervention groups: 1 of 4 treatment groups: soy protein $(18 \mathrm{~g})+$ isoflavone tablets $(105 \mathrm{mg})$, soy protein + placebo tablets, control protein $(18 \mathrm{~g})+$ isoflavone tablets, and control protein + placebo tablets. It was observed that soy protein and isoflavones (either alone or together) did not affect BMD (34).

On the contrary, some studies support the idea that vegetable protein could have a positive effect on calcium and bone metabolism. A study evaluating calcium metabolism in postmenopausal women observed that urinary calcium excretion was significantly lower $(\mathrm{p}<0.01)$ with consumption of either of the soy diets: soy protein isolate enriched with isoflavones $(65 \mathrm{mg})$ and soy protein isolate devoid of isoflavones $(3.1 \mathrm{mg})$ than with consumption of casein-whey protein isolate (control diet) (35). In addition a prospective cohort of 63,257 Chinese observed a significant association of soy protein and isoflavones with hip fracture risk among women. Those in the second-fourth quartiles exhibited $21 \%-36 \%$ reductions in risk of hip fracture (all $\mathrm{p}=0.036)(36)$.

Calcium intake should be also considered to evaluate the effect of source of protein on bone health. Appleby et al. (2007) comparing fracture rates in four diet groups (meat eaters, fish eaters, vegetarians and vegans) in the Oxford cohort of the European Prospective Investigation into Cancer and Nutrition (EPIC-Oxford) observed over an average of 5.2 years of follow-up that compared with meat eaters, fracture incidence rate ratios in men and women combined adjusted for sex, age and non-dietary factors were 1.01 (95\%CI, 0.88-1.17) for fish eaters, 1.00 (95\%CI, 0.891.13) for vegetarians and $1.30(95 \% \mathrm{CI}, 1.02-1.66)$ for vegans. After further adjustment for dietary energy and calcium intake the incidence rate ratio among vegans compared with meat eaters was 1.15 (95\%CI, 0.89-1.49). Among subjects consuming at least $525 \mathrm{mg} / \mathrm{d}$ calcium the corresponding incidence rate ratios were 
1.05 (95\% CI, 0.90-1.21) for fish eaters, 1.02 (95\%CI, 0.90-1.15) for vegetarians and 1.00 (95\% CI, 0.69-1.44) for vegans. The higher fracture risk in the vegans appeared to be a consequence of their considerably lower mean calcium intake (37).

Finally in a recent meta-analysis it was observed no significant effect for total protein on the relative risk of fractures in the highest compared with the lowest quintile/quartile of total protein intake [RR 0.75 (95\%CI, 0.47-1.21, $\mathrm{p}=0.24)$ ] animal protein [RR $0.83(95 \% \mathrm{CI}, 0.54-1.30, \mathrm{p}=0.42)]$ and vegetal protein [RR $1.21(95 \% \mathrm{CI}$, $0.82-1.79, \mathrm{p}=0.34)]$. However in cross-sectional surveys, all pooled $r$ values for the relation between protein intake and BMD or BMC at the main clinically relevant sites were significant and positive; protein intake explained 1-2\% of BMD (38).

\section{EFFECT OF DIETARY PROTEIN ON MUSCLE MASS}

\section{Effect of quantity of protein intake on muscle mass}

The recent report of the Health Aging and Body Composition Study confirms the importance of protein intake in preserving lean body mass on a large population basis. Changes in body composition were determined over a 3-year period in more than 2000 individuals aged 70-79 years. After adjustment for potentially confounding covariates, individuals in the highest quintile of protein intake $(56.0 \mathrm{~g} / \mathrm{d}$ or $0.8 \mathrm{~g} / \mathrm{kg} / \mathrm{d})$ had $40 \%$ less loss in lean body mass over the 3-year period than those in the lowest quintile of protein intake $(91.0 \mathrm{~g} / \mathrm{d}$ or $1.2 \mathrm{~g} / \mathrm{kg} / \mathrm{d})(39)$.

Low protein intake may cause depletion of protein stores, essentially muscle mass, leading to an impairment of overall condition and increasing risk of disability and falls (40). In malnourished and frail elderly, Bos et al (41) and Chevalier (42) observed that increasing dietary protein intake from 0.5 to $2.0 \mathrm{~g}$ protein $/ \mathrm{kg} /$ day resulted in progressively greater rates of whole body protein synthesis and improved nitrogen balance at the end of the diet period. Also Thalacker-Mercer et al (43) reported that low protein intake $(0.5 \mathrm{~g} / \mathrm{kg} /$ day $)$ by older adults results in muscle wasting, when compared to older adults consuming amounts of dietary protein $(1.2 \mathrm{~g} / \mathrm{kg} /$ day $)$.

However, concerns exist regarding high protein intake, mainly in the elderly. It is agreed that there is evidence that high protein intake (up to $2.0 \mathrm{~g} / \mathrm{kg} / \mathrm{d}$ ) could 
increase risk for impaired kidney function in healthy men and women (44). A recent study in health elders showed that an increase in daily protein intake ( 0.9 to $2.1 \mathrm{~g} / \mathrm{kg} / \mathrm{d}$ ) for 10 days expressed changes in $57.7 \%$ glomerular filtration rate (GFR) when compared to younger participants. Also the cohort of nurse's healthy study observed that women with mild renal insufficiency, high-protein diets $(>1.3 \mathrm{~g} / \mathrm{kg} / \mathrm{d})$ may lead to glomerular hyperfiltration (45).

Furthermore, there is general agreement that moderately increasing daily protein intake beyond $0.8 \mathrm{~g} / \mathrm{kg} / \mathrm{d}$ may enhance muscle protein anabolism and provide the reducing the progressive loss of muscle mass with age. On the other hand, initial screening and subsequent monitoring of renal function and creatinine clearance may also be prudent in older individuals (46).

\section{Effect of source of protein intake on muscle mass}

In addition to the quantity of protein, the source of protein has to be considered since there are differences in the essential amino acids (EAA) content of proteins, which are required to avoid negative nitrogen $(\mathrm{N})$ balance and acutely improve muscle protein balance in the elderly (47). Boersheim et al (48) and Volpi et al (49) observed that an oral administration of EAA mixture to healthy elderly resulted in an increased transport of phenylalanine into the muscle leg and also increased lean body mass, strength, and functional test scores. Another randomized study of an orally administered special mixture of amino acids (AAs) observed a significantly increased of protein turnover rates of $8 \%$ and $12 \%$ in the supplemented group while rates of protein turnover decreased $11 \%$ and $9 \%$ in the control subjects at 3 and 12 months, respectively (50).

Also there is a dose-dependent response of muscle protein synthesis to EAA intake. Recent studies (51) have shown that the maximal stimulation of muscle protein synthesis is achieved with approximately $35 \mathrm{~g}$ of high quality protein that contains $15 \mathrm{~g}$ of all EAAs. Among the EAAs, the branched-chain amino acid (BCAA) leucine has been shown to be a key regulator of muscle protein synthesis (52-54).

Katsanos et al (55) showed that a small bolus of essential amino acids (EAAs; $7 \mathrm{~g}$ ) was insufficient to stimulate muscle protein synthesis in elderly subjects, 
whereas the same authors in another study observed that while both a $26 \%(1.72 \mathrm{~g}$ leucine) and a $41 \%$ (2.79g leucine) of leucine essencial amino acid bolus increased muscle protein synthesis in young men, only $41 \%$ leucine EAA bolus was effective in elderly (56).

Also, recent data suggest that a moderate $113 \mathrm{~g}$ serving of protein (lean beef) contains sufficient amino acids (30g total; $10 \mathrm{~g}$ essential amino acids) to increase muscle protein synthesis by approximately $50 \%$ in elderly men and women (57). Also a study has been conducted on elderly women who consumed 3 diets differing in both the quantity and source of protein (diet A: 5.3\% of energy intake provided by animal protein and $5.0 \%$ by vegetable protein; diet B: $14.5 \%$ of energy provided by animal protein and $5.1 \%$ by vegetable protein; diet C: $5.0 \%$ of energy provided by animal protein and $15.1 \%$ by vegetable protein). The diets were consumed for 2 weeks with a 2-weeks interval between diets. There was no effect of feeding on protein synthesis.

However, with the high-vegetable protein diet, protein breakdown in the absorptive state was not inhibited to the same extent as it was with the high-animal protein diet, resulting in less net protein synthesis during the high-vegetable protein diet than during the high-animal (58). Lord et al observed an association between muscle mass index and animal protein intake in older women and a stepwise regression analysis showed that animal protein intake was the only independent predictor of muscle mass index $\left(\mathrm{r}^{2}=0.19 ; \mathrm{p}=0.008\right)$ (59).

Finally, a serving of protein of high biological value should be considered in an adequate diet since its positive effect on muscle protein anabolism. 


\section{CONCLUSION}

In conclusion, aging is associated with a progressive loss of bone and muscle mass, in part due to protein and amino acid homeostasis. There is reasonable evidence to believe that protein intake higher than RDA $(0.8 \mathrm{~g} / \mathrm{kg} / \mathrm{day})$ is might required for the elderly. Therefore, ensuring adequate dietary protein intake using high quality proteins and adequate calcium intake is essential for bone and muscle mass in the elderly in particular. Though evaluate renal function is important since its decrease with ageing. Finally protein and calcium intake should be considered for the prevention or treatment of the chronic diseases as osteoporosis and sarcopenia. 


\section{REFERENCES}

1. Holloszy JO. The biology of aging. Mayo Clin Proc 2000;75 (Suppl):S3-S8.

2. Johnell O, Kanis J. Epidemiology of osteoporotic fractures. Osteoporos Int. 2005;16:S3-S7.

3. Wilsgaard T, Emaus N, Ahmed LA, Grimnes G, Joakimsen RM, Omsland TK, Berntsen GR. Lifestyle Impact on Lifetime Bone Loss in Women and Men The Troms $\varnothing$ Study. Am J Epidemiol. 2009 Jan 27. [Epub ahead of print]

4. Rolland Y, Abellan van Kan G, Bénétos A, Blain H, Bonnefoy M, Chassagne P, Jeandel C, Laroche M, Nourhashémi F, Orcel P, Piette F, Ribot C, Ritz P, Roux C, Tallandier J, Trémollières F, Wevha G, Vellas B. Frailty, osteoporosis and hip fracture: causes, consequences and therapeutic perspectives. J Nutr Health Aging. 2008 May;12(5):335-46.

5. Timmerman KL, Volpi E. Amino acid metabolism and regulatory effects in aging Curr Opin Clin Nutr Metab Care. 2008;11:45-49.

6. Lytras A, Tolis G. Assessment of endocrine and nutritional status in age-related catabolic states of muscle and bone. Curr Opin Clin Metab Care. 2007;10:604610.

7. Institute of Medicine. Dietary reference intakes for energy, carbohydrate, fiber, fat, fatty acids, cholesterol, protein, and amino acids. Washington, DC: National Academies Press, 2002.

8. Campbell WW, Johnson CA, McCabe GP, Carnell NS. Dietary protein requirements of younger and older adults. AmJ Clin Nutr 2008;88:1322-9.

9. Campbell WW, Trappe TA, Wolfe RR, Evans WJ. The recommended dietary allowance for protein may not be adequate for older people to maintain skeletal muscle. J Gerontol A Biol Sci Med Sci 2001;56:M373-80.

10. Fulgoni III VL. Current protein intake in America: analysis of the National Health and Nutrition Examination Survey, 2003-2004. Am J Clin Nutr. 2008;87(suppl):1554S-7S.

11. Bonjour JP. Dietary protein: an essential nutrient for bone health. J Am Coll Nutr 2005;24:526S-36S. 
12. Rizzoli R, Bonjour JP. Dietary protein and bone health. J Bone Miner Res 2004;19:527-31.

13. Fontana L, Weiss EP, Villareal DT, Klein S, Holloszy JO. Long-term effects of calorie or protein restriction on serum IGF-1 and IGFBP-3 concentration in humans. Aging Cell. 2008 Oct;7(5):681-7.

14. Ammann P, Bourrin S, Bonjour JP, Meyer JM, Rizzoli R. Protein undernutritioninduced bone loss is associated with decreased IGF-I levels and estrogen deficiency. J Bone Miner Res. 2000;15:683-690.

15. Schurch MA, Rizzoli R, Slosman D, Vadas L, Vergnaud P, Bonjour JP. Protein supplements increase serum insulin-like growth factor-I level and attenuate proximal femur bone loss in patients with recent hip fracture. A randomized, double-bind, placebo-controlled trial. Ann Intern Med. 1998;128(10):801-809.

16. Drummond MJ, Rasmussen BB. Leucine-enriched nutrients and the regulation of mammalian target of rapamycin signalling and human skeletal muscle protein synthesis. Curr Opin Clin Nutr Metab Care 2008;11:222-226.

17. Wullschleger S, Loewith R, Hall MN. TOR signaling in growth and metabolism. Cell 2006;124:471-484.

18. Hannan MT, Tucker KL, Dawson-Hughes B, Cupples LA, Felson DT, Kiel DP. Effect of dietary protein on bone loss in elderly men and women: the Framingham Osteoporosis Study. J Bone Miner Res. 2000;15(12):2504-12.

19. Kestetter LE, Looker AC, Insogna KL. Low dietary protein and low bone density. Calci Tissue Intern. 2000;66:313.

20. Munger RG, Cerhan JR, Chiu BC. Prospective study of dietary protein intake and risk of hip fracture in postmenopausal women. Am J Clin Nutr. 1999;69:147-52.

21. Wengreen HJ, Munger RG, West NA, Cutler DR, Corcoran CD, et al. Dietary protein intake and risk of osteoporotic hip fracture in elderly residents of Utah. J Bone Miner Res. 2004;19:537-45.

22. Kerstetter JE, O'Brien KO, Insogna KL. Low protein intake: The impact on calcium and bone homeostasis in humans. J Nutr 2003;133:855S-861S.

23. Barzel US,Massey LK. Excess dietary protein can adversely affect bone. J Nutr 1998;128:1051-1053. 
24. Hunt JR, Johnson LK, Roughead ZKF. Hunt JR, Johnson LK, Roughead ZKF. Dietary protein and calcium interact to influence calcium retention: a controlled feeding study. Am J Clin Nutr. 2009;89:1357-65.

25. Kerstetter JE, O'Brien KO, Caseria DM, Wall DE, Insogna KL. The impact of dietary protein on calcium absorption and kinetic measures of bone turnover in women. J Clin Endocrinol Metab. 2005 Jan;90(1):26-31.

26. Feskanich D, Willett W, Stampfer M, Colditz G. Protein consumption and bone fractures in women. Am J Epidemiol 1996;143:472-9.

27. Dargent-Molina PD, Sabia S, Touvier M, Kesse E, Bréart G, Clavel-Chapelon F, Boutron-Ruault MC. Proteins, Dietary Acid Load, and Calcium and Risk of Postmenopausal Fractures in the E3N French Women Prospective Study. J Bone Miner Res. 2008;23:1915-1922.

28. Meyer, H. E., Pedersen, J. I., Loken, E. B. \& Tverdal, A. Dietary factors and the incidence of hip fracture in middle-aged Norwegians. A prospective study. Am. J. Epidemiol. 1997;145:117-123.

29. Evans EM, Racette SB, Van Pelt RE, Peterson LR, Villareal DT. Effects of soy protein isolate and moderate exercise on bone turnover and bone mineral density in postmenopausal women. Menopause. 2007;14(3 Pt 1):481-8.

30. Larsson S, Wolk K, Brismar K, Wolk A. Association of diet with serum insulinlike growth factor I in middle-aged and elderly men. Am J Clin Nutr 2005;81:1163-7.

31. Roughead Z. Johnson L, Lykken G, Hunt J. Controlled high meat diets do not affect calcium retention or indices of bone status in healthy postmenopausal women. J Nutr. 2003;133:1020-6.

32. Lau EM, Kwok T, Woo J, Ho SC. Bone mineral density in Chinese elderly female vegetarians, vegans, lacto-vegetarians and omnivores. Eur J Clin Nutr.1998;52(1):60-4.

33. Promislow JHE, Goodman-Gruen D, Slymen DJ, Barrett-Connor E. Protein Consumption and Bone Mineral Density in the Elderly The Rancho Bernardo Study. Am J Epidemiol 2002;155:636-44.

34. Kenny AM, Mangano KM, Abourizk RH, Bruno RS, Anamani DE, Kleppinger A, Walsh SJ, Prestwood KM, Kerstetter JE. Soy proteins and isoflavones affect bone 
mineral density in older women: a randomized controlled Trial. Am J Clin Nutr 2009;90:234-42.

35. Spenc LA, Lipscomb ER, Cadogan J, Martin B, Wastney ME, Peacock M, Weaver CM. The effect of soy protein and soy isoflavones on calcium metabolism in postmenopausal women: a randomized crossover study. Am J Clin Nutr $2005 ; 81: 916-22$.

36. Koh WP, Wu AH, Wang R, Ang LW, Heng D, Yuan JM, Yu MC. Genderspecific Associations Between Soy and Risk of Hip Fracture in the Singapore Chinese Health Study. Am J Epidemiol. 2009 Aug 31. [Epub ahead of print]

37. Appleby P, Roddam A, Allen N, Key T. Comparative fracture risk in vegetarians and nonvegetarians in EPIC-Oxford. Eur J Clin Nutr. 2007 Dec;61(12):1400-6.

38. Darling AL, Millward DJ, Torgerson DJ, Hewitt CE, Lanham-New SA. Dietary protein and bone health: a systematic review and meta-analysis. Am J Clin Nutr. 2009 Dec;90(6):1674-92.

39. Houston DK, Nicklas BJ, Ding J, Harris TB, Tylavsky FA, Newman AB, et al. Dietary protein intake is associated with lean mass change in older, communitydwelling adults: the Health, Aging and Body Composition (Health ABC) Study. Am J Clin Nutr. 2008;87:150-5.

40. Bauer JD, Isenring E, Torma J, Horsley P, Martineau J. Nutritional status of patients who have fallen in an acute care setting. J Hum Nutr Diet. 2007 Dec;20(6):558-64.

41. Bos C, Benamouzig R, Bruhat A, Roux C, Valensi P, Ferriere F, et al. Nutritional status after short-term dietary supplementation in hospitalized malnourished geriatric patients. Clin Nutr 2001;20:225-33.

42. Chevalier S, Gougeon R, Nayar K, Morais JA. Frailty amplifies the effects of aging on protein metabolism: role of protein intake. Am J Clin Nutr 2003;78:4229.

43. Thalacker-Mercer AE, Fleet JC, Craig BA, Carnell NS, Campbell WW. Inadequate protein intake affects skeletal muscle transcript profiles in older humans. Am J Clin Nutr. 2007;85(5):1344-52. 
44. Walrand S, Short KR, Bigelow ML, Sweatt AJ, Hutson SM, Nair KS. Functional impact of high protein intake on healthy elderly people. Am J Physiol Endocrinol Metab. 2008;295(4):E921-8.

45. Knight EL, Stampfer MJ, Hankinson SE, Spiegelman D, Curhan GC. The impact of protein intake on renal function decline in women with normal renal function or mild renal insufficiency. Ann Intern Med. 2003;138:460-467.

46. Friedman AN. High-protein diets: potential effects on the kidney in renal health and disease. Am J Kidney Dis 2004;44:950-62.

47. Millward DJ, Layman DK, Tomé D, Schaafsma G. Protein quality assessment: impact of expanding understanding of protein and amino acid needs for optimal health. Am J Clin Nutr. 2008 May;87(5):1576S-1581S.

48. Boersheim E, Bui QU, Tissier S, Kobayshi H, Ferrando AA, Wolfe RR. Amino acid supplementation improves muscle mass, strength and physical function in elderly. Clin Nutr. 2008;27(2):189-95.

49. Volpi E, Mittendorfer B, Wolf SE, Wolfe RR. Oral amino acids stimulate muscle protein anabolism in the elderly despite higher first-pass splanchnic extraction. Am J Physiol 1999; 277:E513-20.

50. Baier S, Johannsen D, Abumrad N, Rathmacher JA, Nissen S, Flakoll P. Yearlong Changes in Protein Metabolism in Elderly Men and Women Supplemented With a Nutrition Cocktail of $\beta$-Hydroxy- $\beta$-methylbutyrate (HMB), L-Arginine, and L-Lysine. J Parenter Enteral Nutr. 2009;33: 71-82

51. Rieu I, Balage M, Sornet $\mathrm{C}$, et al. Leucine supplementation improves muscle protein synthesis in elderly men independently of hyperaminoacidaemia. J Physiol 2006; 575:305-315.

52. Dillon EL, Sheffield-Moore M, Paddon-Jones D, Gilkison C, Sanford AP, Casperson SL, Jiang J, Chinkes DL, Urban RJ. Amino acid supplementation increases lean body mass, basal muscle protein synthesis, and insulin-like growth factor-I expression in older women. J Clin Endocrinol Metab. 2009 May;94(5):1630-7.

53. Koopman R, Verdijk L, Manders RJ, Gijsen AP, Gorselink M, Pijpers E, Wagenmakers AJ, van Loon LJ. Co-ingestion of protein and leucine stimulates 
muscle protein synthesis rates to the same extent in young and elderly lean men. Am J Clin Nutr. 2006 Sep;84(3):623-32.

54. Katsanos CS, Chinkes DL, Paddon-Jones D, Zhang XJ, Aarsland A, Wolfe RR. Whey protein ingestion in elderly persons results in greater muscle protein accrual than ingestion of its constituent essential amino acid content. Nutr Res. 2008 Oct;28(10):651-8.

55. Katsanos CS, Kobayashi H, Sheffield-Moore M, Aarsland A, Wolfe RR. Aging is associated with diminished accretion of muscle proteins after the ingestion of a small bolus of essential amino acids. Am J Clin Nutr 2005;82:1065-73.

56. Katsanos CS, Kobayashi H, Sheffield-Moore M, Aarsland A, Wolfe RR. A high proportion of leucine is required for optimal stimulation of the rate of muscle protein synthesis by essential amino acids in the elderly. Am J Physiol Endocrinol Metab. 2006 Aug;291(2):E381-7

57. Symons TB, Schutzler SE, Cocke TL, Chinkes DL, Wolfe RR, Paddon-Jones D. Aging does not impair the anabolic response to a protein-rich meal. Am J Clin Nutr 2007;86:451-6.

58. Pannemans DL, Wagenmakers AJ, Westerterp KR, et al. Effect of protein source and quantity on protein metabolism in elderly women. Am J Clin Nutr 1998; 68:1228-35.

59. Lord C, Chaput JP, Aubertin-Leheudre M, Labonté M, Dionne IJ. Dietary animal protein intake: association with muscle mass index in older women. J Nutr Health Aging.2007;11(5):383-7. 
Table 1: Effect of protein intake on bone mass

\begin{tabular}{|c|c|c|c|}
\hline References & Subjects & Nutritional caractheristics & Outcomes \\
\hline Hannan et al (2000) & Elderly women and men & Protein $68 \mathrm{~g} /$ day ( $16 \%$ of energy) & Protective against spinal and femoral bone loss \\
\hline Kestetter et al (2000) & Post menopausal women & Protein $>75 \mathrm{~g} /$ day & Positive association between protein intake and total BMD \\
\hline Munger et al (1999) & 40,000 Post menopausal women & High protein intake & Reduction $69 \%$ risk of hip fracture \\
\hline Wengreen et al (2004) & 2500 women and men (50-69y) & High protein intake (17.4-30.8\% of energy intake) & Reduction $65 \%$ risk of hip fracture \\
\hline Hunt et al (2009) & Healthy postmenopausal women & High dietary protein $(10 \%-20 \%$ of energy intake) & Decreased urinary deoxypyridinoline and increased serum IGF-1 \\
\hline Kestetter et al (2005) & 10 women $(55-70 y)$ & Moderate $(1.0 \mathrm{~g} / \mathrm{kg} / \mathrm{d})$ or high $(2.1 \mathrm{~g} / \mathrm{kg} / \mathrm{d})$ protein intake & $\begin{array}{l}\text { The high-protein diet caused a significant reduction in urinary calcium and a } \\
\text { nonsignificant reduction in the rate of bone turnover. }\end{array}$ \\
\hline Feskanich et al (1996) & 85,900 women $(53-59 y)$ & More than $95 \mathrm{~g} / \mathrm{d}$ and low calcium intake $(\leq 541 \mathrm{mg} /$ day $)$ & Increase in risk of forearm fracture [RR $1.22(95 \% \mathrm{Cl} 1.04-1.43)]$ \\
\hline Dargent-Molina et al (2008) & 2408 women & Lowest quartile of calcium and high protein intake & Increased in risk fracture [RR1.51 $(95 \% \mathrm{Cl} 1.17-1.94)]$ \\
\hline Meyer et al (1997) & Elderly women and men & Protein intake $(20.6 \mathrm{~g} / \mathrm{d})+$ Low Calcium intake $(435 \mathrm{mg} / \mathrm{d})$ & Double the risk of hip fracture (RR1.96, Cl 95\% 1.09-3.56) \\
\hline \multicolumn{4}{|c|}{ Effect of quality of protein intake on bone mass } \\
\hline References & Subjects & Nutritional caractheristics & Outcomes \\
\hline Evans et al (2007) & 572 women; 388 men (55-92y) & For every $15 \mathrm{~g} /$ day increase in animal protein & $\begin{array}{l}\text { Hip BMD increased by } 0.016 \mathrm{~g} / \mathrm{cm}^{2} \text {, at the femoral neck } 0.012 \mathrm{~g} / \mathrm{cm}^{2} \text {, at the } \\
\text { spine } 0.015 \mathrm{~g} / \mathrm{cm}^{2} \text {, and total body } 0.010 \mathrm{~g} / \mathrm{cm}^{2} \text {. }\end{array}$ \\
\hline Larsson et al (2005) & $\begin{array}{l}226 \text { free-living healthy men }(42- \\
76 y) \text {. }\end{array}$ & Consumption of red meat $(31.2 \mathrm{~g})$ & Positive correlation between IGF- 1 and consumption of red meat $(p=0.05)$ \\
\hline Roughead et al (2003) & 15 postmenopausal women & $\begin{array}{l}\text { High-meat diet ( } 117 \mathrm{~g} \text { of protein) vs low-meat diet }(45 \mathrm{~g} \text { of } \\
\text { protein) }\end{array}$ & $\begin{array}{l}\text { Controlled high meat diets do not affect calcium retention or indices of bone } \\
\text { status in healthy postmenopausal women }\end{array}$ \\
\hline Lau et al (1998) & Vegetarian Chinese women & Vegetable protein & Decrease in hip bone mineral density \\
\hline Promislow et al (2002) & Postmenopausal women & Soy protein intake & No impact on bone mineral density \\
\hline
\end{tabular}




\section{Continuance of table 1}

\begin{tabular}{|c|c|c|c|}
\hline Kenny et al (2009) & 131 health women $(60 y)$ & Soy protein + isofalvone & No effect on BMD (either alone or together) \\
\hline Spenc et al (2005) & Postmenopausal women & Vegetable based protein & Less urinary calcium excretion \\
\hline Koh et al (2009) & 63,257 Chinese & Soy protein + isofalvone & Second-fourth quartiles exhibited $21 \%-36 \%$ reduction of hip fracture \\
\hline Appleby et al (2007) & $\begin{array}{l}7947 \text { men and } 26,749 \text { women } \\
(20-89 \mathrm{y})\end{array}$ & $\begin{array}{l}\text { Fish eaters, vegetarians and vegans diet + Low calcium } \\
\text { intake }(<525 \mathrm{mg} / \mathrm{d})\end{array}$ & $\begin{array}{l}\text { Low calcium intake + vegans diet, Fracture risck [RR } 1.30(95 \% \mathrm{Cl} 1.02 \text { - } \\
1.66)\end{array}$ \\
\hline Darling et al (2009) & Meta-analysis & Total protein inake & $\begin{array}{l}\text { Positive association between } \mathrm{BMD} \text { and } \mathrm{BMC} \text { and protein intake. Also } \\
\text { protein intake explain } 1-2 \% \text { of } \mathrm{BMD}\end{array}$ \\
\hline
\end{tabular}


Table 2: Effect of protein intake on muscle mass

\begin{tabular}{|c|c|c|c|}
\hline References & Subiects & Nutritional caractheristics & Outcomes \\
\hline Houston et al (2008) & 2000 Individuals (70-79 y) & Protein intake $(91.0 \mathrm{~g} / \mathrm{d})$ & $40 \%$ less loss in lean body mass \\
\hline Bos te al (2001) & Malnourished hospitalized patients & Protein intake $1.0,1.5$ and $2.0 \mathrm{~g} / \mathrm{kg} / \mathrm{d}$ & Greater rates of whole body protein synthesis and improved nitrogen balance \\
\hline Chevalier et al (2003) & Frail Women & Protein intake 0.87 to $1.23 \mathrm{~g} / \mathrm{kg} / \mathrm{d}$ & Increase in net endogenous protein balance and positive nitrogen balance \\
\hline Thalacker-Mercer et al (2007) & Older adults & $0.5 \mathrm{~g} / \mathrm{kg} / \mathrm{d}$ and $1.2 \mathrm{~g} / \mathrm{kg} / \mathrm{d}$ & Muscle wasting compared to high protein intake \\
\hline \multicolumn{4}{|c|}{ Effect of quality of protein intake on bone mass } \\
\hline References & Subjects & Nutritional caractheristics & Outcomes \\
\hline Boersheim et al (2008) & Healthy elderly people & Oral administration of $30 \mathrm{~g}$ EAAs & Increase in lean body mass, strength and functional test scores \\
\hline Volpi et al (1999) & $\begin{array}{l}\text { Healthy young and elderly } \\
\text { subjects }\end{array}$ & $\begin{array}{l}\text { Oral administration of aa mixture and infusion of } \\
\text { Phenylalanine }\end{array}$ & $\begin{array}{l}\text { Phenylalanine transport into the muscle, muscle protein synthesis, and net } \\
\text { balance increased significantly }(P<0.01)\end{array}$ \\
\hline Baier (2009) & Elderly (76years) women & $\begin{array}{l}\text { Supplement of beta-hydroxy-beta-methylbutyrate, } \\
\text { L-arginine, and L-lysine }\end{array}$ & The rates of protein turnover were significantly increased $12 \%$ in one year \\
\hline Rieu et al (2006) & Elderly Men & Leucine supplementation & Improve muscle protein synthesis \\
\hline Katsanos et al (2005) & Elderly & $7 g$ EAAS & Inefficient in stimulating protein synthesis \\
\hline Katsanos et al (2006) & Elderly & $6.7 \mathrm{~g}$ of EAAs $-41 \%$ of leucine $(2.79 \mathrm{~g})$ & EAAs can reverse an attenuated response of muscle protein synthesis \\
\hline Symons et al (2007) & Elderly men and women & $113 \mathrm{~g}$ serving of an intact protein (lean beef) & Increase muscle protein synthesis by approximately $50 \%$ \\
\hline Pannemans et al (1998) & Elderly women & Animal protein and vegetable protein & $\begin{array}{l}\text { Less net protein synthesis during the high-vegetable protein diet than during } \\
\text { the high-animal }\end{array}$ \\
\hline Lord et al (2007) & Elderly women & Animal protein intake & $\begin{array}{l}\text { Animal protein intake was the only independent predictor of muscle mass } \\
\text { index }\left(r^{2}=0.19 ; p=0.008\right)\end{array}$ \\
\hline
\end{tabular}


Artigo 2:

“Relação entre consumo de proteína, composição corporal e massa óssea de mulheres com sarcopenia” 


\section{RELAÇÃO ENTRE CONSUMO DE PROTEÍNA, COMPOSIÇÃO CORPORAL E MASSA ÓSSEA DE MULHERES COM SARCOPENIA.}

Patrícia de Souza Genaro, Marcelo de Medeiros Pinheiro, Vera Lúcia Szejnfeld, Lígia Araújo Martini.

Faculdade de saúde Pública - Universidade de São Paulo

Disciplina de Reumatologia - Universidade Federal de São Paulo

\section{Autor correspondente}

Lígia Araújo Martini

Departamento de Nutrição, Faculdade de Saúde Pública - Universidade de São Paulo Av. Dr. Arnaldo, 175 - Cerqueira César, Cep 01246-904, São Paulo, Brasil

Email: 1martini@usp.br

Telefone: 11 3061-7859

Fax: 11 3061-7771 


\section{Resumo}

O consumo alimentar inadequado, principalmente, à ingestão de proteína parece contribuir para a redução da massa muscular esquelética e óssea em idosos. O objetivo deste estudo foi avaliar o consumo de proteína e sua relação com a massa óssea e muscular. Participaram 35 mulheres com sarcopenia e 165 sem sarcopenia acima de 65 anos. Foi avaliado densidade mineral óssea da coluna lombar e fêmur, a composição corporal por meio do densitômetro de dupla emissão de raios-X e a ingestão alimentar pelo registro alimentar de três dias. Os resultados do presente estudo demonstram que a massa muscular, massa óssea e gordura corporal se apresentaram aumentas quando o consumo de proteína estava acima de 1,2 g/kg/dia. Pode-se observar também menor consumo de aminoácidos essenciais em mulheres com sarcopenia. Além disso, o consumo de proteína se associou positivamente com o índice de massa muscular esquelética $(\mathrm{p}=0,028)$ e a DMO do trocânter $(\mathrm{p}=0,010)$. Como conclusão, os resultados demonstram que o consumo de proteína acima de $1,2 \mathrm{~g} / \mathrm{kg} /$ dia parece ser benéfico para a massa óssea e muscular, além disso a escolha da proteína a ser consumida deve conter aminoácidos essenciais. Estes fatores denotam a importância da adequação no consumo de proteína para prevenção na redução da massa muscular e óssea de mulheres idosas.

Descritores: consumo de proteína, idoso, sarcopenia, aminoácidos essenciais, massa óssea, composição corporal. 


\begin{abstract}
The inadequate food intake mainly protein intake seems to contribute to the reduction of skeletal muscle mass and bone in the elderly. The objective was to evaluate protein intake and its relationship with bone muscle mass. The study included 35 women with sarcopenia and 165 women without sarcopenia, over 65 years. Bone mineral density of lumbar spine and femur and body composition was assessed by dual-energy $\mathrm{x}$-ray absorptiometry and evaluation of protein intake through three-day dietary records. Muscle, bone and fat mass is significantly higher in women who presented protein intake above $1.2 \mathrm{~g} / \mathrm{kg} / \mathrm{day}$. Also is observed lower intake of essential amino acids in women with sarcopenia. Furthermore, the protein intake was positively associated with the index of skeletal muscle mass $(p=0.028)$ and trochanter BMD $(\mathrm{p}=0.010)$. In conclusion, these results demonstrate that protein intake above $1.2 \mathrm{~g} / \mathrm{kg} / \mathrm{day}$ appears to be beneficial for bone and muscle mass, also protein should contain essential amino acids. These factors demonstrate the importance of adequate consumption of protein to prevent the reduction of muscle and bone mass in elderly women.
\end{abstract}

Key words: protein intake, elderly, sarcopenia, essential amino acids, bone mass, body composition. 


\section{Introdução}

Com o envelhecimento ocorrem mudanças na composição corporal como, por exemplo, a redução da massa muscular esquelética, denominada sarcopenia e a redução da massa óssea contribuem para o surgimento da osteoporose ${ }^{1}$. Essas mudanças na composição corporal estão relacionadas com maior risco de quedas e fraturas, o que ocasiona maior prevalência de incapacidade e dependência em $\operatorname{idosos}^{2,3}$

Diversos aspectos estão associados com sarcopenia e osteoporose, como fatores hormonais, genéticos e ambientais. Dentre os últimos o consumo alimentar e, principalmente, a ingestão de proteína ${ }^{4}$.

Um dos mecanismos pelos quais a proteína dietética poderia afetar o músculo esquelético é através da otimização da absorção de aminoácidos, promovendo estimulação e regulação da síntese proteica muscular ${ }^{5,6,7}$. Os aminoácidos essenciais, em particular, os de cadeia ramificada como a leucina, podem estimular a síntese proteica muscular em idosos ${ }^{8}$. O consumo de proteína também tem papel importante sobre a massa óssea, pois um terço do volume ósseo é composto por matriz proteica. Essas proteínas são essenciais para a síntese de colágeno tipo I e envolvem modificações pós-translacionais de aminoácidos como lisina e hidroxiprolina ${ }^{9,10}$.

Chevalier e colaboradores (2003) demonstraram que o consumo inadequado de proteína $(0,5 \mathrm{~g} / \mathrm{kg} / \mathrm{dia})$ promove diminuição da massa muscular em idosos ${ }^{11}$. Além disso, o consumo adequado de aminoácidos essenciais parece ser importante para estimular a síntese protéica muscular em idosos e poderia reverter ou atenuar o declínio muscular com o envelhecimento ${ }^{12}$.

Considerando a relação entre o osso, músculo e ingestão proteica o objetivo desse estudo consiste em avaliar o consumo de proteína em mulheres com diminuição de massa muscular e sua realção com a massa óssea e muscular.

\section{Metodologia}

$\underline{\text { População de estudo }}$ 
Foram recrutadas mulheres com idade igual ou superior a 65 anos no período de fevereiro de 2007 a dezembro de 2009. O recrutamento foi realizado por meio de telefonemas realizado pela pesquisadora para as pacientes cadastradas no banco de dados do serviço de densitometria óssea do Hospital São Paulo, Disciplina de Reumatologia da Universidade Federal de São Paulo e residentes na área metropolitana de São Paulo que realizavam densitometria óssea no Instituto de diagnóstico por Imagem (IDI).

Considerando a prevalência ${ }^{13,14}$ de sarcopenia entre 3,0\% (Castillo e col., 2003) e 22,6\% (Iannuzzi-Sucich e col., 2002) em mulheres acima de 60-65 anos, ou em média $12,8 \%$ o cálculo do tamanho amostral foi realizado segundo Levine (2000) ${ }^{15}$. O valor obtido foi de 172 mulheres, no entanto, amostra final foi composta por 200 mulheres devido a potencia perda de 15\%, 35 mulheres com sarcopenia e 165 sem sarcopenia. Foram adotados como critérios de exclusão: mulheres que necessitavam de auxílio para locomoção, doença neuromuscular primária conhecida, qualquer tipo de câncer e mielomas, insuficiência renal (creatinina sérica $>1,2 \mathrm{mg} / \mathrm{dL}$ ) ou hepática, pulmonar, doença cérebro vascular, déficit cognitivo que os impossibilitassem de fornecer respostas, tais como seqüelas neurológicas, demências senis, institucionalizadas e hospitalizadas.

As mulheres foram avaliadas após explicação do projeto e assinatura do termo de consentimento, conforme preconiza a resolução no. 196 do Conselho Nacional de Saúde, de 10 de outubro de 1996.

\section{Avaliação da composição corporal e massa óssea}

A avaliação da densidade mineral óssea e a composição corporal foram realizadas pelo densitômetro de dupla emissão com fonte de raios-X (GE-Lunar, modelo DPX-MD plus, WI, USA).

Para o estudo da composição corporal foram avaliados massa muscular total, massa muscular esquelética, massa adiposa, densidade mineral óssea (DMO) do corpo total e conteúdo mineral ósseo do corpo total.

As mulheres foram classificadas como sarcopênicas quando a massa muscular esquelética fosse menor ou igual a dois desvios-padrão da população de referência ${ }^{1}$. 
A população de referência utilizada por Baumgartner foi um estudo de Rosetta $^{16}$ que avaliou 284 mulheres saudáveis com idade entre 18-40 anos.

O índice de massa muscular esquelética (IMME) foi calculado a partir da determinação de massa muscular esquelética apendicular (massa muscular das pernas e dos braços) em quilos do indivíduo dividido pelo quadrado da estatura em metros ${ }^{1}$, ou seja: $\mathrm{IMME}=$ massa muscular esquelética dos Braços + Pernas (kg)/Altura ${ }^{2}(\mathrm{~m})$, sendo considerada sarcopenia quando a massa muscular esquelética apendicular fosse menor ou igual a dois desvios-padrão da população feminina de referência, ou seja, o valor encontrado estivesse abaixo de $5,45 \mathrm{~kg} / \mathrm{m}^{2}$.

\section{Avaliação de força muscular}

Para determinar a força muscular foi utilizado o dinamômetro de força de preensão palmar da marca Jamar®. Para a realização das mensurações, os indivíduos foram posicionados sentados com o braço aduzido paralelo ao tronco, cotovelo fletido a 90 graus e antebraço e punho em posição neutra. Foram realizadas três medições com intervalo mínimo de um minuto entre elas, no lado dominante, e anotada a média dos três valores ${ }^{17}$.

\section{$\underline{\text { Avaliação do consumo alimentar }}$}

Para avaliar o consumo alimentar foi solicitado um registro alimentar de três dias, incluindo um dia do final de semana. Neste registro, as pacientes foram instruídas a anotar todos os alimentos e bebidas consumidos ao longo do dia, em medidas caseiras.

Os dados obtidos pelo registro alimentar de três dias foram transformados em energia e nutrientes pelo programa NDSR - Nutrition Data System for Research Universidade de Minnessota, 2007. Para avaliação da adequação do consumo de proteína foi utilizado o método EAR (estimate average requirement) como ponto de corte para verificar a proporção de indivíduos cuja ingestão do nutriente estava inadequada, proposto pelo Institute of Medicine - DRI 2002 ${ }^{18}$. Esse número corresponde à área da curva abaixo desse valor de referência.

$\mathrm{Na}$ avaliação do consumo alimentar foram consideradas apenas as pacientes com ingestão calórica entre 500 e $3500 \mathrm{kcal} / \mathrm{dia}$, sendo assim duas pacientes sem 
sarcopenia foram excluídas das análises por apresentarem ingestão inferior a 500 kcal. Além disso, para controlar o efeito do consumo de energia proveniente da dieta nos micronutrientes avaliados foi aplicado o método do nutriente residual, proposto por Willet e Stamper (1998) ${ }^{19}$.

Para o cálculo da estimativa de carga ácida proveniente da dieta, foi utilizado a proposta de Fransseto e colaboradores $(2007)^{20}$ que determina NEAP (net endogenous acid production) e PRAL (potencial renal acid load), segundo as fórmulas abaixo:

$\operatorname{NEAP}(\mathrm{mEq} /$ dia $)=[54,5$ x proteína $(\mathrm{g} /$ dia $) /$ potássio $(\mathrm{mEq} / \mathrm{dia})]-10,2$

PRAL $(\mathrm{mEq} / \mathrm{dia})=0,49 \mathrm{x}$ proteína $(\mathrm{g} / \mathrm{dia})+0,037 \mathrm{x}$ fósforo $(\mathrm{mg} / \mathrm{dia})-0,021 \mathrm{x}$ potássio $(\mathrm{mg} /$ dia $)$ - 0,026 x magnésio $(\mathrm{mg} /$ dia $)$ - 0,013 x cálcio $(\mathrm{mg} / \mathrm{dia})$

\section{$\underline{\text { História clínica }}$}

$\mathrm{Na}$ avaliação da história clínica, foi questionada quanto, tabagismo, medicação em uso atual, comorbidades e atividade física. As pacientes ativas foram as que informaram praticar exercício físico ou esporte de intensidade moderada por pelo menos 30 minutos diários em cinco ou mais dias da semana; ou exercício físico ou esporte de intensidade vigorosa por pelo menos 20 minutos diários em pelo menos três dias por semana e/ou realizar atividades domésticas ${ }^{21}$. As pacientes sedentárias foram aquelas que informaram não fazer exercícios físicos ou esportes, não andar freqüentemente a pé e não ser responsável pela limpeza pesada de suas residências ${ }^{22}$.

\section{$\underline{\text { Análise estatística }}$}

Os resultados foram apresentados em média e desvios-padrão. A distribuição normal foi verificada por meio do teste Kolmogorov-Smirnov. As variáveis com distribuição normal foi aplicado o teste t-student para comparação de médias do consumo de nutrientes entre mulheres com e sem sarcopenia, para as variáveis que não apresentaram distribuição normal (idade e força muscular) foi utilizado o teste não paramétrico de Mann-Whitney. O teste Qui-quadrado foi utilizado para comparações de prevalências entre os grupos. A correlação de Pearson foi aplicada 
para verificar a associação entre o consumo de proteína e os parâmetros da composição corporal e massa óssea.

Para a análise dos níveis do consumo de proteína segundo composição corporal e massa óssea foi realizado a Análise de Variância Simples (Oneway ANOVA) e em seguida do teste post-hoc de Tukey para comparações múltiplas.

As análises estatísticas foram conduzidas no programa Statistical Package for the Social Sciences, versão 12.0 (SPSS Inc. Chicago. IL). O nível de significância adotado para os testes estatísticos foi $5 \%(\mathrm{p}<0,05)$.

\section{Resultados}

As principais características da população estudada podem ser observadas na tabela 1. Não houve diferença significativa quanto à idade, hábito de fumar, condições de saúde, dependência leve ao que se refere às atividades instrumentais da vida diária (AIVD) e as atividades básicas da vida diária (AVD). A atividade física foi semelhante em ambos os grupos, cabe salientar ainda que nenhuma das mulheres realizava exercício de força (musculação) e a atividade física predominante foi a caminhada, pois $13 \%$ das pacientes a realizavam. Além disso não houve diferença significativa $(\mathrm{p}=0,824)$ na proporção de mulheres que realizavam atividade física segundo consumo de proteína.

Conforme o esperado as mulheres com sarcopenia apresentaram significantemente menor massa muscular total, esquelética e força muscular. Além da contribuição da massa muscular para a diminuição do peso nas mulheres com sarcopenia, a massa óssea também esteve diminuída. Embora o IMC tenha se apresentado menor nas mulheres com sarcopenia quando comparadas sem mulheres

sem sarcopenia [23,49 $(3,75)$ vs. $26,61(3,81) \mathrm{kg} / \mathrm{m}^{2}$; $\left.\mathrm{p}<0,001\right]$, não houve diferença na adiposidade corporal entre os grupos, ademais nenhuma das pacientes com sarcopenia apresentaram características que pudessem estar relacionadas à caquexia.

Quanto ao consumo alimentar, não houve diferença significativa na ingestão de energia proveniente da dieta entre mulheres com e sem sarcopenia. Na tabela 2, pode-se observar que não houve diferença significante no consumo de proteína total, proteína animal e proteína vegetal em mulheres com e sem sarcopenia 
respectivamente. Além disso, ambos os grupos apresentaram 4\% de inadequação do consumo de proteína. No entanto o consumo de aminoácidos essenciais como a treonina $[2,28(0,68)$ vs. $2,57(0,82)$ g/dia, p=0,033], lisina [4,02 $(1,23)$ vs. 4,52 $(1,58) \mathrm{g} / \mathrm{dia}, \mathrm{p}=0,036]$ e aminoácidos de cadeia ramificada como a valina $[3,10(0,89)$ vs. 3,40 (1,04) g/dia, $\mathrm{p}=0,044]$ foi significantemente menor nas mulheres que apresentavam sarcopenia quando comparado com mulheres sem sarcopenia respectivamente e uma tendência no menor consumo de isoleucina $[2,71(0,78)$ vs. $3,01(0,93) \mathrm{g} / \mathrm{dia}, \mathrm{p}=0,052]$ por mulheres com sarcopenia.

Quanto aos parâmetros que medem a carga ácida proveniente da dieta não houve associação com os parâmetros de sarcopenia e a massa óssea. Adicionalmente não houve diferença significativa da carga ácida proveniente da dieta entre mulheres com e sem sarcopenia.

Na tabela 3, ao avaliarmos a composição corporal e densidade óssea segundo os níveis de ingestão de proteína, pode-se observar que as pacientes que apresentavam um consumo de proteína acima de $1,2 \mathrm{~g} / \mathrm{kg} / \mathrm{dia}$ apresentaram massa muscular total, massa muscular esquelética apendicluar, gordura corporal, CMO do corpo total, DMO de corpo total, DMO coluna lombar, DMO colo de fêmur e DMO fêmur total significativamente maior quando comparado com pacientes que apresentavam consumo de proteína abaixo de $0,8 \mathrm{~g} / \mathrm{kg} / \mathrm{dia}$.

Na figura 1 estão apresentadas as correlações entre parâmetros que determinam a sarcopenia e a massa óssea com o consumo de proteína. A DMO do trocânter se correlacionou positivamente com o consumo de proteína $(\mathrm{r}=0,185 ; \mathrm{p}=0,010)$ e houve também tendência na correlação entre DMO do colo de fêmur e o consumo de proteína $(\mathrm{r}=0,126 ; \mathrm{p}=0,080)$. Quanto à composição corporal, o índice de massa muscular esquelética apendicular se correlacionou positivamente com o consumo de proteína $(\mathrm{r}=0,157 ; \mathrm{p}=0,028)$. Além disso, o consumo de proteína animal se correlacionou positivamente com DMO corpo total $(\mathrm{r}=0,161 ; \mathrm{p}=0,024)$ e com a DMO trocânter $(r=0,199 ; p=0,005)$. Não houve correlação entre o consumo de proteína animal e o índice de massa muscular esquelética. A proteína vegetal também não se associou com a massa óssea e os parâmetros de sarcopenia. 


\section{Discussão}

O presente estudo observou que o consumo de proteína não foi diferente entre ambos os grupos, entretanto, as pacientes que consumiam proteína acima de $1,2 \mathrm{~g} / \mathrm{kg} / \mathrm{dia}$ apresentavam melhor massa muscular quando comparado com as mulheres que consumiam proteína abaixo de $0,8 \mathrm{~g} / \mathrm{kg} / \mathrm{dia}$. Thalacker-Mercer e colaboradores $^{23}$ observaram que o consumo inadequado de proteína $(0,5 \mathrm{~g} / \mathrm{kg} / \mathrm{dia})$ resultava em diminuição de massa muscular em idosos. Além disso, estudos avaliando o aumento da ingestão de proteína de $0,5 \mathrm{~g} / \mathrm{kg} / \mathrm{dia}$ para $1,2 \mathrm{~g} / \mathrm{kg} / \mathrm{dia}$ demonstraram aumento no metabolismo protéico e melhora no balanço nitrogenado em idosos ${ }^{24}$. Estudo de base populacional também confirmou a importância do consumo de proteína para minimizar a perda de massa muscular. Os participantes que estavam no menor quintil de ingestão protéica $(0,8 \mathrm{~g} / \mathrm{kg} / \mathrm{dia})$ tinham $40 \%$ menos perda de massa muscular comparado com quem estava no maior quintil de ingestão $(1,2 \mathrm{~g} / \mathrm{kg} / \mathrm{dia})^{25}$.

A massa óssea, também se apresentou aumentada com o consumo de proteína acima de 1,2g/kg/dia. Estudo epidemiológico de Framingham avaliando uma coorte de idosos por um período de quatro anos observou que o alto consumo de proteína (menor quartil $0,21-0,71 \mathrm{~g} / \mathrm{kg} / \mathrm{dia}$ e maior quartil $1,24-2,78 \mathrm{~g} / \mathrm{kg} / \mathrm{dia}$ ) era protetor para perda de massa óssea tanto na coluna como no fêmur ${ }^{26}$. Ademais no estudo NHANES III, o consumo de proteína acima de $75 \mathrm{~g} /$ dia foi associado positivamente com a densidade mineral óssea do quadril em mulheres na pós-menopausa ${ }^{27}$.

A gordura corporal se apresentou aumentada nas pacientes que consumiam proteína acima de $1,2 \mathrm{~g} / \mathrm{kg} / \mathrm{dia}$. Estudo de coorte avaliando o consumo de proteína e a composição corporal não observou o mesmo resultado, pois as mulheres que estavam no maior tercil de ingestão de proteína $(1,64 \mathrm{~g} / \mathrm{kg} / \mathrm{dia})$ apresentavam atividade física significantemente maior (614 vs. $466 \mathrm{~kJ} / \mathrm{d}$ ) quando comparada com o primeiro tercil $(0,84 \mathrm{~g} / \mathrm{kg} / \mathrm{d})^{28}$. O consumo de proteína associado à atividade física parece promover maior massa muscular e óssea e menor gordura corporal.

Além disso, 4\% das mulheres com sarcopenia e 4\% das mulheres sem sarcopenia apresentaram consumo de proteína abaixo da EAR. O consumo de proteína observado foi de $65,8 \mathrm{~g} / \mathrm{dia}$ ou $1,1 \mathrm{~g} / \mathrm{kg} / \mathrm{dia}$. Na população americana o 
consumo de proteína abaixo da EAR foi de 4,4\% nas mulheres entre 51-70 anos e $5,9 \%$ nas mulheres acima de $71 \operatorname{anos}^{29}$. Na população brasileira, Pinheiro e colaboradores $^{30}$ (2009) observaram que as mulheres acima de 40 anos apresentavam menor consumo de proteína $(60,5 \mathrm{~g} / \mathrm{d}$ ou $0,94 \mathrm{~g} / \mathrm{kg} / \mathrm{dia})$ quando comparado com este estudo.

Campbell e colaboradores $(2008)^{31}$ avaliando os valores determinados para EAR e RDA, por meio do balanço nitrogenado, observaram que a necessidade média de proteína em adultos $(0,61 \mathrm{~g} / \mathrm{kg} / \mathrm{dia})$ era similar a necessidade de idosos saudáveis $(0,58 \mathrm{~g} / \mathrm{kg} / \mathrm{dia})$. No entanto, os valores de recomendação para EAR $(0,66 \mathrm{~g} / \mathrm{kg} / \mathrm{dia})$ e RDA $(0,88 \mathrm{~g} / \mathrm{kg} / \mathrm{dia})$ parecem ser maiores que o assumido, uma vez que a necessidade poderia estar aumentada devido ao estado catabólico presente em muitas doenças crônicas não transmissíveis ${ }^{32}$. Estudo de coorte avaliando mulheres idosas por um período de 10 anos observou que naquelas com o consumo de proteína entre $1,2-1,7 \mathrm{~g} / \mathrm{kg} / \mathrm{dia}$ houve menor relato de doenças quando comparado com mulheres que consumiam menos de $0,8 \mathrm{~g} / \mathrm{kg} / \mathrm{dia}^{33}$. Além disso, segundo alguns autores a ingestão de 1,5 g de proteína/ $\mathrm{kg} /$ dia ou de $20-30 \mathrm{~g}$ de proteína por refeição, seria uma meta razoável para os idosos que desejam otimizar o consumo de proteína em termos de prevenção de doenças crônicas não transmissíveis como a sarcopenia e a osteoporose $\mathrm{s}^{34,35,36}$.

Este estudo também observou que as mulheres com sarcopenia apresentaram menor consumo de aminoácidos essenciais incluindo aqueles de cadeia ramificada. Katsanos e colaboradores ${ }^{37}$ (2006) observaram que a ingestão de $6,7 \mathrm{~g}$ de aminoácidos essenciais com uma proporção de $41 \%$ de aminoácidos de cadeia ramificada parece promover maior síntese de proteínas musculares em idosos. Dados semelhantes foram observados por Paddon-Jones e colaboradores $(2006)^{38}$ com a suplementação de aminoácidos essenciais e de cadeia ramificada. Estudo avaliando o efeito da dose de proteína sobre o anabolismo de proteínas no músculo por meio de um alimento fonte de proteína e aminoácidos essenciais observou que $113 \mathrm{~g}$ de carne magra (30g de proteína e $220 \mathrm{Kcal})$ estimulou a síntese protéica ${ }^{39}$.

Embora a proteína de origem animal, fonte de aminoácidos essenciais, possa talvez contribuir na indução de acidose metabólica ocasionando balanço negativo de cálcio e conseqüentemente perda de massa óssea, quando, associado à baixa ingestão 
de cálcio, o presente estudo não mostrou associação entre o consumo de proteína de origem animal e a carga ácida proveniente da dieta, no entanto, se associou positivamente com a massa óssea. Fenton e colaboradores $(2009)^{40} \mathrm{em}$ um estudo de meta-análise não encontraram evidências que comprovasse o efeito da acidose metabólica no balanço de cálcio e metabolismo ósseo. Adicionalmente um estudo de coorte avaliando 572 mulheres e 388 homens com idade entre 55-92 anos, análise de regressão linear múltipla ajustada para covariáveis importantes, demonstrou associação positiva com o consumo de proteína animal. Para cada aumento de $15 \mathrm{~g} /$ dia na ingestão de proteína animal, observou-se aumento da DMO quadril $\left(0,016 \mathrm{~g} / \mathrm{cm}^{2} ; \mathrm{p}=0,005\right)$, DMO colo de fêmur $\left(0,012 \mathrm{~g} / \mathrm{cm}^{2} ; \mathrm{p}=0,02\right)$, DMO coluna $\left(0,015 \mathrm{~g} / \mathrm{cm}^{2} ; \mathrm{p}=0,08\right)$ e DMO de corpo total $\left(0,010 \mathrm{~g} / \mathrm{cm}^{2} ; \mathrm{p}=0,04\right)^{41}$.

Além disso o consumo de proteína se associou positivamente com o índice de massa muscular esquelética apendicular, utilizado para classificação da sarcopenia. Corroborando com esses achados, estudo avaliando a associação da qualidade da proteína com a massa muscular observou que o consumo de proteína animal, que contém maior quantidade de aminoácidos essenciais, contribuía, independentemente de outros fatores para o índice de massa muscular $\left(\mathrm{r}^{2}=0.19 ; \mathrm{p}=0.008\right)^{42}$.

No que se refere às limitações do estudo, a definição utilizada para sarcopenia não considera a força muscular. Embora a medida de força tenha sido significantemente menor no grupo com sarcopenia, a mensuração tanto da quantidade de massa muscular como força estão envolvidos no declínio da capacidade funcional deste tecido. Além disso, o ponto de corte utilizado para diagnosticar sarcopenia esta baseado na população americana, uma vez que não dispomos da curva de normalidade para a massa muscular em nossa população.

Como conclusão, os resultados demonstram que o consumo de proteína acima de $1,2 \mathrm{~g} / \mathrm{kg} /$ dia parece ser benéfico para a massa óssea e muscular, além disso a proteína consumida deve conter aminoácidos essenciais. Estes fatores denotam a importância da intervenção nutricional com adequação no consumo de proteína associado à atividade física para prevenção na redução da massa muscular e óssea de mulheres idosas. 


\section{Referências bibliográficas}

1. Baumgartner RN, Koehler KM, Gallagher D, et al. Epidemiology of sarcopenia among the elderly in New Mexico. Am J Epidemiol. 1998; 147:755-763.

2. Melton LJ, Khosla S, Crowson CS, O’Connor MK, O’Fallon M, Riggs BL. Epidemiology of sarcopenia. J Am Geriatr Soc. 2000;48:625-630.

3. Janssen I, Heymsfield SB, Ross R. Low relative skeletal muscle mass (sarcopenia) in older persons is associated with functional impairment and physical disability. J Am Geriatr Soc. 2002;50:889-896.

4. Doherty TJ. Invited review: Aging and sarcopenia. J Appl Physiol. 2003;95: 1717-27.

5. Timmerman KL, Volpi E. Amino acid metabolism and regulatory effects in aging Curr Opin Clin Nutr Metab Care. 2008;11:45-49.

6. Volpi E, Kobayashi H, Sheffield-Moore M, Mittendorfer B, Wolfe RR. Essential amino acids are primarily responsible for the amino acid stimulation of muscle protein anabolism in healthy elderly adults. Am J Clin Nutr 2003;78:250-58.

7. Dorrens $\mathbf{J}$ and Rennie MJ. Effects of ageing and human whole body and muscle protein turnover. Scand J Med Sci Sports. 2003;13:26-33.

8. Fujita S, Volpi E. Amino Acids and Muscle Loss with Aging. J Nutr. 2006;136: 277S-280S.

9. Heaney RP, Layman DK. Amount and type of protein influences bone health. Am J Clin Nutr. 2008;87:1567-70.

10. Dawson-Hughes B. Calcium and protein in bone health. Proc Nutr Soc. 2003;62:505-9.

11. Chevalier S, Gougeon R, Nayar K, Morais JA. Frailty amplifies the effects of aging on protein metabolism: role of protein intake. Am $\mathrm{J}$ Clin Nutr 2003;78:422-9.

12. Douglas Paddon-Jones D, Short KR, Campbell WW, Volpi E, Wolfe RR. Role of dietary protein in the sarcopenia of aging. Am J Clin Nutr. 2008;87:15621566. 
13. Castillo EM, Goodman-Gruen D, Kritz-Silverstein D, Morton DJ, Wingard DL, Barrett-Connor E. Sarcopenia in Elderly Men and Women The Rancho Bernardo Study. Am J Prev Med. 2003;25:226-31.

14. Iannuzzi-Sucich M, Prestwood KM, Kenny AM. Prevalence of sarcopenia and predictors of skeletal muscle mass in healthy, older men and women. J Gerontol A Biol Sci Med Sci. 2002;57:772-77.

15. Levine DM, Berenson ML, Stephan D. Estatística: Teoria e Aplicações usando Microsoft Excel em Português. Rio de Janeiro: LTC; 2000.

16. Gallagher D, Visser M, De Meersman RE, Sepúlveda D, Baumgartner RN, Pierson RN, Harris T, Heymsfield SB. Appendicular skeletal muscle mass: effects of age, gender, and ethnicity. J Appl Physiol. 1997. 83(1): 229-39.

17. Harkonen R, Harju R, Alaranta H. Accuracy of the Jamar dynamometer. J Hand Ther 1993;6:259-262.

18. Standing Committee on the Scientific Evaluation of Dietary Reference Intake, Food and nutrition Board, Institute of Medicine. Dietary reference intake for Energy, carbohydrate, fiber, fat, protein and acids (macronutrient). Washington, DC: National Academy Press; 2002.

19. Willet W, Stampfer M. Implications of totl energy intake for epidemiological analyses. In: Willet W. Nutritional epidemiology. 2nd ed. New York: Oxford University Press; 1998.

20. Frassetto LA, Lanham-New SA, Macdonald HM, Remer T, Sebastian A, Tucker KL, Tylavsky FA. Standardizing terminology for estimating the diet-dependent net acid load to the metabolic system. J Nutr. 2007;137:1491-2.

21. World Health Organization (WHO). Global strategy on diet, physical activity and health. Geneva: WHO, 2004. (Fifty-Seventh World Health Assembly, WHA57.17).

22. Pate RR, Pratt M, Blair SN, Haskell WL, Macera CA, Bouchard C, Buchner D, Ettinger W, Heath GW, King AC, et al. Physical activity and public health: a recommendation from the centers for disease control and prevention and the American College of Sports Medicine. JAMA. 1995;273:402-07. 
23. Thalacker-Mercer AE, Fleet JC, Craig BA, Carnell NS, Campbell WW. Inadequate protein intake affects skeletal muscle transcript profiles in older humans. Am J Clin Nutr. 2007;85(5):1344-52.

24. Bos C, Benamouzig R, Bruhat A, Roux C, Valensi P, Ferriere F, et al. Nutritional status after short-term dietary supplementation in hospitalized malnourished geriatric patients. Clin Nutr 2001;20:225-33.

25. Houston DK, Nicklas BJ, Ding J, Harris TB, Tylavsky FA, Newman AB, et al. Dietary protein intake is associated with lean mass change in older, communitydwelling adults: the Health, Aging and Body Composition (Health ABC) Study. Am J ClinNutr 2008;87:150-5.

26. Hannan MT, Tucker KL, Dawson-Hughes B, Cupples LA, Felson DT, Kiel DP. Effect of dietary protein on bone loss in elderly men and women: the Framingham Osteoporosis Study. J Bone Miner Res. 2000;15(12):2504-12.

27. Kestetter LE, Looker AC, Insogna KL. Low dietary protein and low bone density. Calci Tissue Intern. 2000;66:313.

28. Meng X, Zhu K, Devine A, Kerr DA, Binns CW, Prince RL. A 5-year cohort study of the effects of high protein intake on lean mass and BMC in elderly postmenopausal women. J Bone Miner Res. 2009;24(11):1827-34.

29. Fulgoni III VL. Current protein intake in America: analysis of the National Health and Nutrition Examination Survey, 2003-2004. Am J Clin Nutr. 2008;87(suppl):1554S-7S.

30. Pinheiro MM, Schuch NJ, Genaro PS, Ciconelli RM, Ferraz MB, Martini LA. Nutrient intakes related to osteoporotic fractures in men and women--the Brazilian Osteoporosis Study (BRAZOS). Nutr J. 2009;8:6.

31. Campbell WW, Johnson CA, McCabe GP, Carnell NS. Dietary protein requirements of younger and older adults. AmJ Clin Nutr 2008;88:1322-9.

32. Fisher AL. Of worms and women: sarcopenia and its role in disability and mortality. J Am Geriatr Soc. 2004;52:1185-90.

33. Vellas BJ, Hunt WC, Romero LJ, Koehler KM, Baumgartner RN, Garry PJ. Changes in nutritional status and patterns of morbidity among free-living elderly persons: a 10-year longitudinal study. Nutrition 1997;13:515-519. 
34. Wolfe R, Miller SL, Miller KB. Optimal protein intake in the elderly. Clinical Nutrition (2008) 27, 675-684.

35. Layman DK. Dietary guidelines should reflect new understandings about adult protein needs. Nutr Metab (Lond). 2009 Mar 13;6:12.

36. Paddon-Jones D, Rasmussen BB. Dietary protein recommendations and the prevention of sarcopenia. Current Opinion in Clinical Nutrition and Metabolic Care 2009, 12:86-90

37. Katsanos CS, Kobayashi H, Sheffield-Moore M, et al. A high proportion of leucine is required for optimal stimulation of the rate of muscle protein synthesis by essential amino acids in the elderly. Am J Physiol Endocrinol Metab 2006; 291:E381-E387.

38. Paddon-Jones D, Sheffield-Moore M, Katsanos CS, et al. Differential stimulation of muscle protein synthesis in elderly humans following isocaloric ingestion of amino acids or whey protein. Exp Gerontol 2006; 41:215-219.

39. Symons TB, Sheffield-Moore M, Wolfe RR, Paddon-Jones D. A moderate serving of high-quality protein maximally stimulates skeletal muscle protein synthesis in young and elderly subjects. J Am Diet Assoc. 2009 Sep;109(9):1582-6.

40. Fenton TR, Lyon AW, Eliasziw M, Tough SC, Hanley DA. Meta-analysis of the effect of the acid-ash hypothesis of osteoporosis on calcium balance. J Bone Miner Res. 2009 Nov;24(11):1835-40.

41. Roughead ZK, Johnson LK, Lykken GI, Hunt JR 2003 Controlled high meat diets do not affect calcium retention or indices of bone status in healthy postmenopausal women. J Nutr 133:1020-1026.

42. Lord C, Chaput JP, Aubertin-Leheudre M, Labonté M, Dionne IJ. Dietary animal protein intake: association with muscle mass index in older women. $\mathbf{J}$ Nutr Health Aging.2007;11(5):383-7. 
Tabela 1: Características gerais de mulheres com e sem sarcopenia.

\begin{tabular}{|c|c|c|c|c|}
\hline Características gerais & $\begin{array}{c}\begin{array}{c}\text { Total } \\
(n=198)\end{array} \\
\end{array}$ & $\begin{array}{c}\text { Sarcopênica } \\
(\mathbf{n}=35)\end{array}$ & $\begin{array}{c}\text { Não Sarcopênica } \\
(n=163)\end{array}$ & $p$ \\
\hline \multicolumn{5}{|l|}{ Dados antropométricos } \\
\hline Idade (anos) & $71,10(5,03)$ & $70,66(5,76)$ & $71,20(4,87)$ & 0,328 \\
\hline Peso $(\mathrm{kg})$ & $59,29(10,14)$ & $53,54(8,46)$ & $60,52(10,06)$ & $<0,001$ \\
\hline Altura $(\mathrm{cm})$ & $150,57(6,22)$ & $151,34(6,43)$ & $150,41(6,18)$ & 0,438 \\
\hline $\operatorname{IMC}\left(\mathrm{kg} / \mathrm{m}^{2}\right)$ & $26,06(3,97)$ & $23,49(3,75)$ & $26,61(3,81)$ & $<0,001$ \\
\hline \multicolumn{5}{|l|}{ Composição corporal } \\
\hline Massa Muscular Total (kg) & $32,61(3,86)$ & $28,90(2,77)$ & $33,41(3,59)$ & $<0,001$ \\
\hline MMEa (kg) & $13,87(2,08)$ & $11,67(1,69)$ & $14,34(1,84)$ & $<0,001$ \\
\hline $\operatorname{IMME}\left(\mathrm{kg} / \mathrm{m}^{2}\right)$ & $6,09(0,72)$ & $5,06(0,38)$ & $6,31(0,57)$ & $<0,001$ \\
\hline Força muscular (kg) & $20,54(4,25)$ & $19,05(2,84)$ & $20,65(4,46)$ & 0,011 \\
\hline Gordura corporal (\%) & $40,51(7,73)$ & $40,62(7,86)$ & $40,48(7,73)$ & 0,924 \\
\hline Gordura corporal $(\mathrm{kg})$ & $23,55(7,17)$ & $22,24(4,29)$ & $23,83(7,63)$ & 0,094 \\
\hline CMO corpo total (g) & $1,869(0,293)$ & $1,778(0,302)$ & $1,888(0,288)$ & 0,054 \\
\hline DMO corpo total $\left(\mathrm{g} / \mathrm{cm}^{2}\right)$ & $1,015(0,098)$ & $0,993(0,873)$ & $1,019(0,100)$ & 0,116 \\
\hline \multicolumn{5}{|l|}{ Densidade Óssea } \\
\hline DMO coluna L1-L4 $\left(\mathrm{g} / \mathrm{cm}^{2}\right)$ & $0,946(0,164)$ & $0,907(0,126)$ & $0,954(0,170)$ & 0,064 \\
\hline DMO colo de fêmur $\left(\mathrm{g} / \mathrm{cm}^{2}\right)$ & $0,785(0,104)$ & $0,755(0,091)$ & $0,792(0,106)$ & 0,040 \\
\hline DMO trocânter $\left(\mathrm{g} / \mathrm{cm}^{2}\right)$ & $0,693(0,133)$ & $0,630(0,102)$ & $0,707(0,111)$ & $<0,001$ \\
\hline DMO fêmur total $\left(\mathrm{g} / \mathrm{cm}^{2}\right)$ & $0,831(0,119)$ & $0,778(0,114)$ & $0,842(0,117)$ & 0,004 \\
\hline \multicolumn{5}{|l|}{ Hábito de vida } \\
\hline \multicolumn{5}{|l|}{ Tabagismo } \\
\hline Atual & $7,6 \%$ & $5,7 \%$ & $8,0 \%$ & 0,083 \\
\hline Passado & $7,6 \%$ & $11,4 \%$ & $28,2 \%$ & \\
\hline Nunca & $25,3 \%$ & $82,9 \%$ & $63,8 \%$ & \\
\hline \multicolumn{5}{|l|}{ Atividade física } \\
\hline Sedentária & $34,9 \%$ & $42,9 \%$ & $38,7 \%$ & 0,644 \\
\hline Ativa & $60,6 \%$ & $57,1 \%$ & $61,3 \%$ & \\
\hline \multicolumn{5}{|l|}{ Condições de saúde } \\
\hline AIVD (independencia) & $99,5 \%$ & $99,4 \%$ & $100 \%$ & 0,642 \\
\hline AIVD (dependência leve) & $24,7 \%$ & $22,9 \%$ & $25,2 \%$ & 0,775 \\
\hline Doenças cardíacas* & $67,2 \%$ & $60,0 \%$ & $69,9 \%$ & 0,252 \\
\hline Doenças endócrinas-metabólica* & $68,2 \%$ & $28,3 \%$ & $20,9 \%$ & 0,188 \\
\hline Uso de TH no passado & $23,2 \%$ & $48,6 \%$ & $34,4 \%$ & 0,144 \\
\hline
\end{tabular}

* Doencas cardíaca: hipertensão arterial sistêmica, doença cardíaca congestiva. Doença endócrinametabólica: hipotiroidismo, diabetes tipo II, dislipidemia.

$\mathrm{MMEa}=$ massa muscular esquelética apendicular IMME= índice de massa muscular esquelética, $\mathrm{CMO}=$ conteúdo mineral ósseo, $\mathrm{DMO}=$ densidade mineral óssea, $\mathrm{AIVD}=$ Atividades Instrumentais da Vida Diária $\mathrm{TH}=$ terapia hormonal. 
Tabela 2: Consumo de proteína e aminoácidos essenciais de mulheres com e sem sarcopenia.

\begin{tabular}{lcccc}
\hline Consumo alimentar & Total & Sarcopenicas & $\begin{array}{c}\text { Não } \\
\text { Sarcopenicas }\end{array}$ & $\boldsymbol{p}$ \\
& $(\mathbf{n = 1 6 3})$ & $(\mathbf{n = 3 5})$ & $\mathbf{n}=\mathbf{1 6 3})$ & \\
\hline Energia (Kcal) & $1339,49(397,47)$ & $1268,87(354,79)$ & $1354,66(404,96)$ & 0,211 \\
Proteína (g/dia) & $65,87(11,93)$ & $63,66(9,79)$ & $66,34(12,32)$ & 0,167 \\
Proteína (\%) & $20,12(3,78)$ & $19,62(3,55)$ & $20,22(3,82)$ & 0,375 \\
Proteína animal (g/dia) & $43,00(13,58)$ & $41,02(10,73)$ & $43,43(14,11)$ & 0,262 \\
Proteína vegetal (g/dia) & $22,80(6,03)$ & $22,57(6,11)$ & $22,85(6,03)$ & 0,809 \\
Proteína (g/kg/dia) & $0,98(0,37)$ & $0,96(0,36)$ & $0,98(0,37)$ & 0,732 \\
Triptofano (g/dia) & $0,76(0,22)$ & $0,72(0,22)$ & $0,77(0,22)$ & 0,212 \\
Treonina (g/dia) & $2,52(0,80)$ & $2,28(0,68)$ & $2,57(0,82)$ & 0,033 \\
Isoleucina (g/dia) & $2,96(0,91)$ & $2,71(0,78)$ & $3,01(0,93)$ & 0,052 \\
Leucina (g/dia) & $5,13(1,57)$ & $4,76(1,37)$ & $5,21(1,60)$ & 0,128 \\
Valina (g/dia) & $3,35(1,02)$ & $3,10(0,89)$ & $3,40(1,04)$ & 0,044 \\
Lisina (g/dia) & $4,43(1,53)$ & $4,02(1,23)$ & $4,52(1,58)$ & 0,036 \\
Metionina (g/dia) & $1,46(0,47)$ & $1,33(0,38)$ & $1,49(0,49)$ & 0,129 \\
Fenilalanina (g/dia) & $2,89(0,86)$ & $2,69(0,75)$ & $2,93(0,88)$ & 0,115 \\
Neap (mEq/dia) & $65,43(19,87)$ & $62,66(17,47)$ & $66,03(20,34)$ & 0,320 \\
Pral (mEq/dia) & $12,31(11,91)$ & $12,14(12,09)$ & $12,35(11,91)$ & 0,927 \\
\hline Nea) & & & \\
\hline
\end{tabular}

Neap=net endogenous acid production, $\mathrm{PRAL}=$ potencial renal acid load 
Tabela 3: Composição corporal e densidade óssea segundo o consumo de proteína.

\begin{tabular}{|c|c|c|c|c|}
\hline $\begin{array}{c}\text { Composição corporal e } \\
\text { densidade óssea }\end{array}$ & $\begin{array}{c}\text { Proteína } \\
<0,8 \\
\text { g/kg/dia }\end{array}$ & $\begin{array}{l}\text { Proteína } \\
0,8-1,2 \\
\text { g/kg/dia }\end{array}$ & $\begin{array}{c}\text { Proteína } \\
>1,2 \mathrm{~g} / \mathrm{kg} / \mathrm{dia}\end{array}$ & p-trend \\
\hline Massa Magra Total (kg) & $31,87(3,52)$ & $32,59(3,49)$ & $33,94(4,72)^{*}$ & 0,020 \\
\hline MMEa (kg) & $13,38(1,95)$ & $13,96(1,94)$ & $14,54(2,38)^{*}$ & 0,013 \\
\hline IMME $\left(\mathrm{kg} / \mathrm{m}^{2}\right)$ & $6,01(0,65)$ & $6,06(0,71)$ & $6,30(0,84)^{*}$ & 0,109 \\
\hline Força muscular (kg) & $19,90(3,63)$ & $20,33(4,56)$ & $21,14(4,62)$ & 0,363 \\
\hline Gordura corporal (\%) & $38,24(7,13)$ & $40,90(8,07)$ & $43,67(6,96)^{* \dagger}$ & 0,001 \\
\hline Gordura corporal (kg) & & & $27,71(8,27)^{* \dagger}$ & 0,001 \\
\hline CMO corpo total (g) & $1,784(0,265)$ & $1,906(0,282)$ & $1,945(0,325)^{* \dagger}$ & 0,005 \\
\hline DMO corpo total $\left(\mathrm{g} / \mathrm{cm}^{2}\right)$ & $0,988(0,090)$ & $1,025(0,095)$ & $1,039(0,109)^{* \dagger}$ & 0,011 \\
\hline DMO coluna L1-L4 (g/cm²) & $0,903(0,131)$ & $0,965(0,168)$ & $0,983(0,192)^{*} \dagger$ & 0,014 \\
\hline DMO colo de fêmur $\left(\mathrm{g} / \mathrm{cm}^{2}\right)$ & $0,760(0,944)$ & $0,795(0,102)$ & $0,813(0,117)^{* \dagger}$ & 0,017 \\
\hline DMO trocanter $\left(\mathrm{g} / \mathrm{cm}^{2}\right)$ & $0,679(0,118)$ & $0,689(0,103)$ & $0,727(0,117)^{*}$ & 0,071 \\
\hline DMO fêmur total $\left(\mathrm{g} / \mathrm{cm}^{2}\right)$ & $0,807(0,116)$ & $0,833(0,107)$ & $0,868(0,135)^{*}$ & 0,026 \\
\hline
\end{tabular}

$\mathrm{MMEa}=$ massa muscular esquelética apendicular, IMME = índice de massa muscular esquelética, $\mathrm{CMO}=$ conteúdo mineral ósseo, $\mathrm{DMO}=$ densidade mineral óssea. ${ }^{*} \mathrm{p}<0,05$ versus $(0,8 \mathrm{~g} / \mathrm{kg} / \mathrm{dia})$; $\dagger \mathrm{p}<0,05$ versus $(0,8-1,2 \mathrm{~g} / \mathrm{kg} / \mathrm{dia})$. 
Figura 1: Correlação entre o consumo de proteína, índice de massa muscular esquelética e densidade mineral óssea em mulheres idosas.

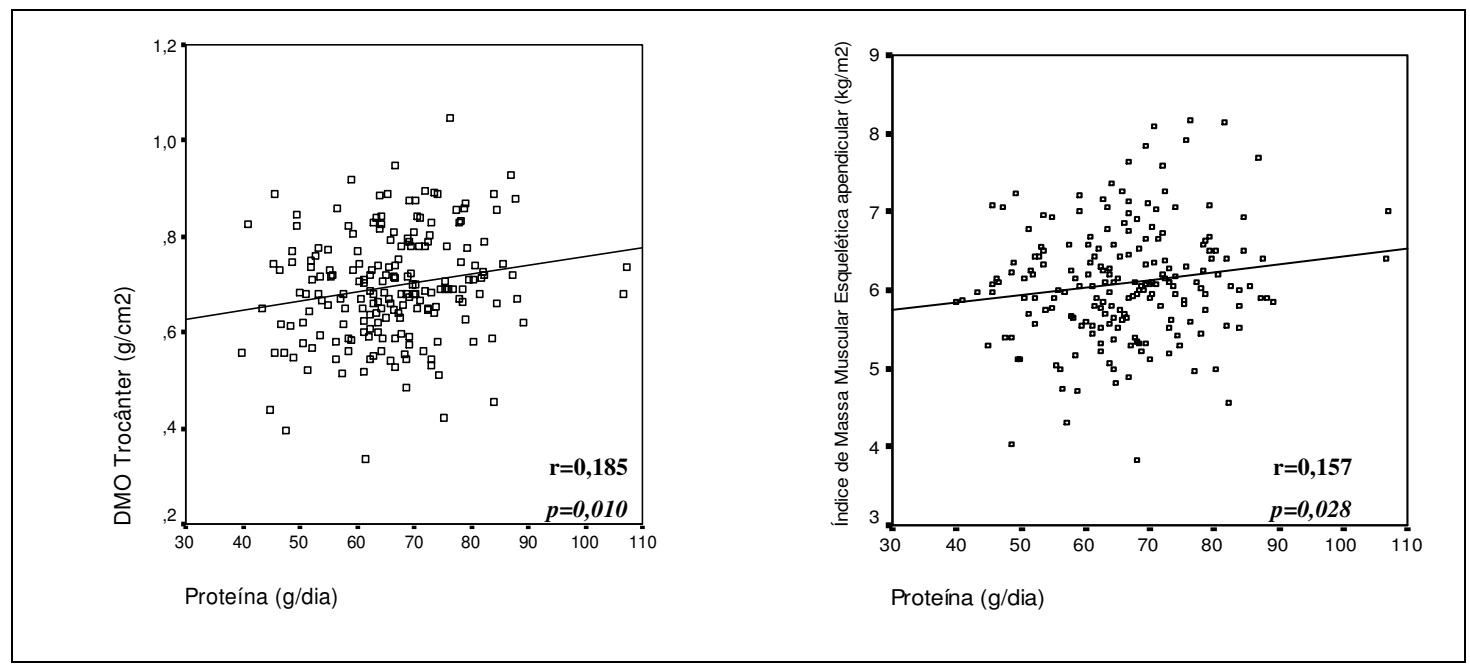


Artigo 3:

"Secondary hyperparathyroidism and its relation with sarcopenia and bone mass in elderly women"

Artigo original

À ser submetido à Osteoporosis International 


\section{SECONDARY HYPERPARATHYROIDISM AND ITS RELATION WITH SARCOPENIA AND BONE MASS IN ELDERLY WOMEN}

Patrícia de Souza Genaro ${ }^{1}$, MS; Marcelo de Medeiros Pinheiro², PHD; Vera Lúcia Szejnfeld ${ }^{2}$, PHD; Lígia Araújo Martini ${ }^{1}, \mathrm{PhD}$.

1 - Nutrition Department, School of Public Health, University of São Paulo 2 - Rheumatology Division, São Paulo Federal University

\section{Corresponding author}

Lígia Araújo Martini, PhD

Nutrition Department, School of Public Health, University of São Paulo

Av Dr Arnaldo, 715. São Paulo, SP, Brazil - 01246904

Email: $\underline{\text { lmartini@usp.br }}$

Phone: 5511 3061-7859

Fax: $55113061-7771$ 


\begin{abstract}
Purpose: The purpose of the study was to evaluate the vitamin D status and its relation to skeletal muscle mass and bone mass in elderly women. Methods: A total of 105 women, being 35 with sarcopenia and 70 with no sarcopenia were enrolled in the present study and both groups were paired by age and weight. Bone mineral density and body composition measurements were performed by DXA and strength was measured using a grip strength dynamometer. Three-day dietary records were undertaken to estimate dietary intake and serum total albumin, calcium, phosphorus, creatinin, intact PTH, 25(OH)D were measured. Results: When deficiency of vitamin $\mathrm{D}$ was associated to elevated PTH $(>65 \mathrm{pg} / \mathrm{dL})$, secondary hyperparathyroidism, the prevalence of sarcopenia was increased (77.1 vs $22.9 \%$; $\mathrm{p}=0.032$ ) and women with secondary hyperparathyroidism had significantly lower total muscle mass [29.70 (2.99) vs 31.84 (3.65); p=0.043], SMMI [5.51 (0.55) vs 5.92 (0.78); $\mathrm{p}=0.043$ ]. Considering only vitamin $\mathrm{D}$ status it was observed in this study high prevalence of vitamin D deficiency in women with sarcopenia (71.4\%) and also women with insufficient of vitamin D presented significantly lower TSMM [30.30 (2.92) vs 32.14 (3.84) kg; p=0.007], ASMM [12.71 (1.59) vs 13.55 (0.82) kg; $\mathrm{p}=0.031$ ]; SMMI [5.67 (0.60) vs $5.98(0.82) \mathrm{kg} / \mathrm{m}^{2} ; \mathrm{p}=0.030$ ] and total femur BMD [0.791 (0.107) vs $\left.0.838(0.116) \mathrm{g} / \mathrm{cm}^{2} ; \mathrm{p}=0.035\right]$. Conclusion: the results of our study suggest that poor vitamin D status and secondary hyperparathyroidism may have an impact on low muscle mass and bone mass with aging. Also this study suggests that $25(\mathrm{OH}) \mathrm{D}$ concentrations should be as high as $50 \mathrm{nmol} / \mathrm{L}$ to avoid low muscle and bone mass and combined calcium plus vitamin D supplementation should be considered as the therapeutic for muscle and bone loss.
\end{abstract}

Key words: deficiency of vitamin D, secondary hyperparathyroidism, sarcopenia, bone mass. 


\section{Introdution}

Vitamin D is involved with the regulation of calcium homeostasis and bone metabolism by exerting its actions on target tissues including gut, kidney, and bone [1]. Increasing evidence indicates that vitamin D also plays an important role in many other tissues including skeletal muscle. The identification of the vitamin D receptor (VDR) on muscle cell provided further support for a direct effect of vitamin D on muscle tissue [2].

The metabolic effect of vitamin D dificiency on bone mass is well known. Vitamin D deficiency leads to reduced active transport of calcium across the intestine. This results in a decline in the circulating ionized calcium concentration, which in turn promotes the secretion of PTH [3]. On muscle cell, deficiency of vitamin D could reduce the uptake of inorganic phosphate, which is important for the production of energy-rich phosphate compounds such as ATP and creatine phosphate, vital for muscle contraction. In addition, intracellular calcium is regulated by VDR localized to the cell membrane [4].

In the past decade, it has been described that prolonged vitamin D deficiency was associated with severe muscle weakness, significantly decline of muscle strength, often leading to marked disability [5,6]. Also low vitamin D level is significantly related to loss of bone mass and elevated fracture risk [7]. Moreover, elderly with low vitamin D status, may be particularly predisposed to proximal myopathy caused by vitamin D deficiency and secondary hyperparathyroidism [8].

Few studies have been conducted in which sarcopenia or skeletal muscle mass was objectively quantified in relation to vitamin D status in elderly people. The purpose of the study was to evaluate the vitamin D status and its relation to skeletal muscle mass and bone mass in elderly women.

\section{Methods}

\section{Subjects}

Women aged over 65 years were screened from February 2007 to December 2008. Recruitment was conducted through phone calls to the patients enrolled in the 
database of bone densitometry at São Paulo Hospital, Rheumatology Division, Federal University of Sao Paulo. Patients were excluded if they had a history of chronic renal failure, alcohol abuse, stroke, asthma, chronic obstructive pulmonary disease, emphysema, myocardial infarction, and diagnosis of any cancer, Parkinson disease, arthritis, stroke. Written informed consent was obtained. The study was approved by the local research ethics committee. A total of 105 women, being 35 with sarcopenia and 70 with no sarcopenia were enrolled in the present study and both groups were paired by age and weight.

\section{Anthropometric, bone mineral density and body composition measurements}

Weight, height and body mass index (BMI) were performed by using standardized techniques. The BMI was calculated dividing weight $(\mathrm{kg})$ by the square of height $\left(\mathrm{m}^{2}\right)$ [9].

Total femur, femoral neck, spine (L1-L4) and total body bone mineral density (BMD) were measured using dual-energy x-ray absorptiometry (DXA - GE-Lunar DPX-MD plus, Madison, WI, USA, version 8.5 software). The device was calibrated daily using a spine phantom and DXA measurements were performed by a trained technician. The coefficient of variation is $3 \%$ (total femur), $2 \%$ (spine) and $0.6 \%$ (total body). Besides, body composition measurements (Total body bone mineral content (BMC), fat mass, total muscle mass and appendicular skeletal muscle mass (ASMM) were also evaluated using DXA scanners.

World Health Organization criteria were used to identify osteoporotic women [10]. Sarcopenia was defined based on appendicular skeletal muscle mass (ASMM) measures [11]. ASMM corresponds to the sum of the 2 upper and lower limb lean masses in kilogram. ASMM was normalized for height (ASMM/height ${ }^{2}$ ). Women were classified as with sarcopenia if their relative appendicular skeletal muscle mass was $>2$ standard-deviations below the mean of a reference population from the Rosetta Study, which included 284 healthy Americans aged 18-40 y [12]. The cutoff corresponded to $5.45 \mathrm{~kg} / \mathrm{m}^{2}$ in women. 


\section{Grip strength}

Grip strength was used as an indicator of muscle strength and is known to be positively correlated with both lower-extremity and upper-body strength in older persons, with reported correlation coefficients between 0.47 and 0.63 [13]. Grip strength was measured using a grip strength dynamometer (Jamar® Hydraulic Hand Dynamometer). The median strength (kilograms) of three attempts of dominant hand was considered [14].

\section{Fracture}

Participants were asked to report all previous fractures. Radiological evaluation of the spine was performed through X-ray of the dorsal and lumbar columns (T4 to L4). The criteria proposed by Genant et al (1993) [15] was used to classify the type and severity of vertebral deformity.

\section{Dietary intake}

Three-day dietary records were undertaken to estimate mean calcium, phosphorus and vitamin D intakes. Dietary intake were analyzed using Nutrition Data System for Research (2007), developed by Nutrition Coordinating Center (NCC), University of Minessota Minneapolis, MN. Adequacy of calcium and vitamin D intake was assessed using the AI guidelines of 1200mg of calcium and 10$15 \mu \mathrm{g}$ of vitamin D [16].

\section{Laboratory measurements}

An overnight fasting blood sample was obtained from each elderly woman. After blood coagulation and centrifugation at 2000rpm for $10 \mathrm{~min}$ at room temperature, serum sample were harvested and frozen at $-80^{\circ} \mathrm{C}$ until analyses for serum total albumin, calcium, phosphorus, creatinine, intact PTH, 25(OH)D. All exams were measured by automated standard laboratory methods, albumin, creatinine, calcium and phosphorus were measured by colorimetric assay and potassium by ion selective electrode. Serum intact PTH concentrations were measured using the chemiluminescence intact immunoassay (Cobas E411 Roche); the normal range in adults is $6-65 \mathrm{pg} / \mathrm{mL}$, with an interassay coefficient of variation 
of $7.0-9.2 \%$. Serum vitamin D concentration was measured using Chromatography High Performance Liquid and deficiency of vitamin D was defined as serum $25(\mathrm{OH}) \mathrm{D}$ concentration $<50 \mathrm{nmol} / \mathrm{L}(20 \mathrm{ng} / \mathrm{dL})[17]$.

Others covariates

A questionnaire was used to obtain information on personal habits and medical history. Participants were queried about cigarette smoking habits including (current, past and never); calcium and vitamin D supplement use (yes/no); 3 months regular physical activity were considered when reported physical exercise or sport of moderate intensity for at least 30 minutes a day on five or more days a week, or exercise or sport of vigorous intensity for at least 20 minutes a day in at least three days a week and/or perform household chores [18,19]. A fall was defined as inadvertently coming to rest on the ground or other lower level without loss of consciousness and other than as a consequence of sudden onset of paralysis, epileptic seizure and had more than two falls in the previous year was defined as recurrent falling [20]. Congestive heart disease, hypertension, dyslipidemia, diabetes was considered as chronic diseases.

\section{Statistical analysis}

The descriptive data are expressed as mean (standard deviation). All variables had normal distribution according to the Kolmogorov-Smirnov test. The Student $\mathrm{t}$ test was used to determine statistical differences among dietary, biochemical and body composition variables between women with and without sarcopenia. Student $t$ teste was also used to determine statistical differences among vitamin D status. The chi-squared test was used to test differences in the distribution of categorical variables. Statistical significance was assumed when $\mathrm{p}<0.05$. The software used was Statistical Package for the Social Sciences version 11.0 for Windows (SPSS Inc., Chicago, IL, USA). 


\section{Results}

General characteristics, body composition and bone mass variables are given in table 1. There were no significant differences in presence of chronic diseases, falls, previous fracture and physical activities, as well as the use of calcium and vitamin D supplements between groups. However, women with sarcopenia reported to smoke significantly less than women with no sarcopenia (5.7 versus $10.0 \%$, $\mathrm{p}=0.04)$, respectively.

Regarding body composition, women with sarcopenia had significantly lower total skeletal muscle mass [28.90 (2.77) vs 32.16 (3.23) kg, p<0.001], appendicular skeletal muscle mass [11.67 (1.69) vs 13.76 (1.74) kg; p<0.001], skeletal muscle mass index [5.06 $(0.38)$ vs $\left.6.18(0.53) \mathrm{kg} / \mathrm{m}^{2} ; \mathrm{p}<0.001\right]$ and grip strength [18.11 (4.42) vs 20.44 (4.31) $\mathrm{kg} ; \mathrm{p}=0.011]$ when compared to women with no sarcopenia. Besides femur BMD was significantly lower when compared to women with no sarcopenia. However, there was no significant difference in the prevalence of osteoporosis between women with and without sarcopenia (60.0 and 58.6\%; $\mathrm{p}=0.888)$, respectively.

Nutritional and biochemical parameters are presented in table 2. There were no differences in nutrient intake between groups. However, mean dietary calcium and vitamin D intake were below of the reccomedation. Only 3,8\% of the patients met the daily adequate intake (AI) recommendation for calcium intake (1200 $\mathrm{mg} /$ day) and none of women met the AI recommendation for vitamin D intake (10$15 \mu \mathrm{g} /$ day). For biochemical parameters, albumin was significantly lower in women with sarcopenia when compared to women with no sarcopenia [4.13 (0.40) vs 4.38 (0.56); $\mathrm{p}=0.018$ ], while mean serum creatinin, calcium, phosphorus, potassium, PTH and serum $25(\mathrm{OH}) \mathrm{D}$ were similar between groups.

Also there was no difference in mean serum $25(\mathrm{OH}) \mathrm{D}$ between groups, However, there was a tendency vitamin D deficiency (serum $25(\mathrm{OH}) \mathrm{D}<50 \mathrm{nmol} / \mathrm{L}$ ) be more prevalent in women with sarcopenia when compared to women with no sarcopenia (71.4 and $51.4 \%, \mathrm{p}=0.050$ ), respectively.

Table 3 presents body composition according to levels of serum 25(OH)D. It was observed that women with vitamin D deficiency presented significantly lower 
total muscle mass [30.30 (2.92) vs 32.14 (3.84) kg; p=0.007], ASMM [12.71 (1.59) vs $13.55(0.82) \mathrm{kg} ; \mathrm{p}=0.031$ ] and SMMI [5.67 (0.60) vs $\left.5.98(0.82) \mathrm{kg} / \mathrm{m}^{2} ; \mathrm{p}=0.030\right]$. Also total femur BMD [0.791 (0.107) vs $\left.0.838(0.116) \mathrm{g} / \mathrm{cm}^{2} ; \mathrm{p}=0.035\right]$ is reduced in presence of serum $25(\mathrm{OH}) \mathrm{D}$ lower than $50 \mathrm{nmol} / \mathrm{L}$. When deficiency of vitamin $\mathrm{D}$ was associated to elevated PTH $(>65 \mathrm{pg} / \mathrm{dL})$, secondary hyperparathyroidism, presented in figure 1, the prevalence of sarcopenia was increased (77.1 vs $22.9 \%$; $\mathrm{p}=0.032$ ). Women with secondary hyperparathyroidism had significantly lower total muscle mass [29.70 (2.996) vs 31.84 (3.65); p=0.043], SMMI [5.51 (0.55) vs 5.92 (0.78); $\mathrm{p}=0.043]$.

Additionally, vertebral fracture had a tendency to be more prevalent in women with deficiency of vitamin D when compared to women with vitamin D over than $50 \mathrm{nmol} / \mathrm{l}(71.9 \%$ vs $28.1 \%$; $=0.058)$ respectively.

\section{Discussion}

This study demonstrated the presence of sarcopenia increases more than $20 \%$ when vitamin D deficiency is associated to PTH levels higher than $65 \mathrm{pg} / \mathrm{dL}$ Women with secondary hyperparathyroidism presented significant low muscle mass. Secondary hyperparathyroidism plays a deleterious role on muscle tissue. Elevated PTH occurs with increasing frequency as the plasma $25(\mathrm{OH}) \mathrm{D}$ falls with a threshold level of around 50nmol/L [21]. Secondary hyperparathyroidism and vitamin D deficiency enhances the risk of bone and muscle loss [22]. The prospective, population-based study by Visser et al, (2003) showed that low 25(OH)D levels and high PTH levels increased the risk of sarcopenia in subjects aged 65 years. Risk of sarcopenia was higher in subjects with baseline $25(\mathrm{OH}) \mathrm{D}$ levels less than $25 \mathrm{nmol} / \mathrm{L}$ as compared to those with levels higher than $50 \mathrm{nmol} / \mathrm{L},(\mathrm{OR}=1.57,95 \% \mathrm{CI} 1.40$ 4.70), based on grip strength and ( $\mathrm{OR}=2.14$, 95\%CI $0.73-6.33)$, based on muscle mass. PTH levels of $4 \mathrm{pmol} / \mathrm{L}$ or higher, as compared to levels under $3 \mathrm{pmol} / \mathrm{L}$, were associated to an increased risk of sarcopenia, with $(\mathrm{OR}=1.71,95 \% \mathrm{CI} 1.07-2.73)$ based on grip strength and $(\mathrm{OR}=2.35,95 \% \mathrm{CI}$ 1.05-5.28) based on muscle mass [23].

In fact patients with primary hyperparathyroidism are often diagnosed with muscular weakness and lazy muscle fatigue. By evaluating the surgical treatment in 
women with primary hyperparathyroidism, Deutch et al (2000) demonstrated an increase in isometric knee extension force after operation. Furthermore, using the superimposed twitch technique authors showed that the change in muscle strength was due to an improvement in the ability of the muscle to generate force, thus confirming that high PTH levels could be deleterious to muscle strength [24].

Also secondary hyperparathyroidism associated to deficiency of vitamin D could be related to low bone mass in women with sarcopenia. Many investigators have observed increased serum PTH concentrations associated with vitamin D deficiency and low bone mass in the elderly [25,26]. Study evaluating 283 patients with hip fracture observed that vitamin D deficiency occurred in $31.7 \%$ and secondary hyperparathyroidism occurred in $17.7 \%$ of cases [27]. Similary a study evaluating healthy adult population found low serum $25(\mathrm{OH}) \mathrm{D}$ concentrations $(<25$ $\mathrm{nmol} / \mathrm{L}$ ) in $26.2 \%$ of the women and based on nonlinear regression analysis the serum PTH concentration started to increase with serum $25(\mathrm{OH}) \mathrm{D}$ concentrations lower than approximately $80 \mathrm{nmol} / \mathrm{L}$ in the women. Also significantly lower forearm BMD was found in this population [28].

Additionally, considering only vitamin D status it was observed in this study high prevalence of vitamin D deficiency in women with sarcopenia (71.4\%) and also low muscle mass in women with deficiency of vitamin D. Muscle cell metabolism is affected by vitamin D insufficiency and it might contribute to sarcopenia [29]. Several mechanisms, including atrophy of type II muscle fibers and reduced nerve conduction velocity may explain this association [30,31]. A study analyzing muscle biopsies in older adults observed that vitamin D deficiency has shown predominantly type II muscle fiber atrophy [32]. Atrophy of type II muscle fibers is associated to lower extremity muscle performance [33]. Analysis of the NHANES III survey, elderly individuals with higher serum 25(OH)D levels up to $94 \mathrm{nmol} / \mathrm{L}$ showed better muscle performance than individuals with lower levels [34], particularly in the subset with $25(\mathrm{OH}) \mathrm{D}$ levels less than $60 \mathrm{nmol} / \mathrm{L}$. In a prospective analysis of the LASA (The Longitudinal Aging Study Amsterdam), older adults with lower serum $25(\mathrm{OH}) \mathrm{D}(<50 \mathrm{nmol} / \mathrm{L})$ were found to be at increased risk of a decline in physical performance over 3 years compared to those with higher levels $(>75 \mathrm{nmol} / \mathrm{L})$ [35]. In a prospective analysis of the Rancho Bernardo Study cohort, elderly women with 
25(OH)D levels $80 \mathrm{nmol} / \mathrm{L}$ or less performed more poorly on lower extremity muscle performance tests compared to women with the highest $25(\mathrm{OH}) \mathrm{D}$ levels at least $115 \mathrm{nmol} / \mathrm{L}$ over a 2.5 -year period [36].

Futhermore, in our study, low mineral density of total fêmur $\left(0.791 \mathrm{~g} / \mathrm{cm}^{2}\right.$; $\mathrm{p}=0,035)$ and a tendency of more prevalence of fracture $(71.9 \% ; \mathrm{p}=0.058)$ also was observed in women with deficiency of vitamin D. In the epidemiologic study of NHANES III it was also observed that higher serum concentrations of $25(\mathrm{OH}) \mathrm{D}$ are associated with higher bone mass of the hip in older men and women [37]. Also a study evaluating 486 postmenopausal women verified a significant negative association between $25(\mathrm{OH}) \mathrm{D}(<50 \mathrm{nmol} / \mathrm{L})$ and bone markers as hydroxyproline $(\mathrm{r}=-$ $0.162 ; \mathrm{p}=0.033)$ and pyridinoline $(\mathrm{r}=-0.129 ; \mathrm{p}=0.011)$ adjusted to creatinine [38]. Similarly, another study evaluating markers of bone turnover, measured in 119 active community dwelling elderly women, demonstrated vitamin D insufficiency $(25(\mathrm{OH}) \mathrm{D}$ between 15 and $30 \mathrm{nmol} / \mathrm{L})$ in $27 \%$ of the group. The serum concentration of osteocalcin and bone alkaline phosphatase activity and urinary excretion of hydroxyproline and deoxypyridinoline were significantly higher in vitamin D insufficient women than in the vitamin D replete group [39].

The multinational European study sponsored by the World Health Organization recently reported the circulating levels of $25(\mathrm{OH}) \mathrm{D}$ in 8532 European osteoporotic women. Values lower than $80 \mathrm{nmol} / \mathrm{L}$ were seen in almost $80 \%$ of women, and approximately one third had levels under $50 \mathrm{nmol} / \mathrm{ml}$, suggesting a high risk of osteoporotic fractures [40]. Addicionaly, Lopes et al evaluating Braziliam community-dwelling elderly women observed that serum levels of $25(\mathrm{OH}) \mathrm{D}$ in the no vertebral fracture group were higher than those observed in the vertebral fracture group $(51.73 \mathrm{nmol} / \mathrm{L}$ vs $42.31 \mathrm{nmol} / \mathrm{L}, \mathrm{p}<0.001)$. After adjustment for significant variables the logistic-regression analyses revealed that age $(\mathrm{OR}=1.09,95 \% \mathrm{CI} 1.04$ 1.14, $\mathrm{p}<0.001)$ femoral neck BMD $(\mathrm{OR}=0.7,95 \% \mathrm{CI} 0.6-0.82, \mathrm{p}<0.001)$ and $25(\mathrm{OH}) \mathrm{D}<75 \mathrm{nmol} / \mathrm{L}(\mathrm{OR}=2.38,95 \% \mathrm{CI} 1.17-4.8, \mathrm{p}=0.016)$ remains a significant factor for vertebral fracture [41].

Regarding dietary intake there was no difference in calcium and vitamin D intake between women with and without sarcopenia, both groups did not met to the recommended values according to The Institute of Medicine's Standing Committee 
on the Scientific Evaluation of Dietary Reference Intakes. Futhermore, Pinheiro et al evaluating bone health-related nutrients intake found that Braziliam women over 40

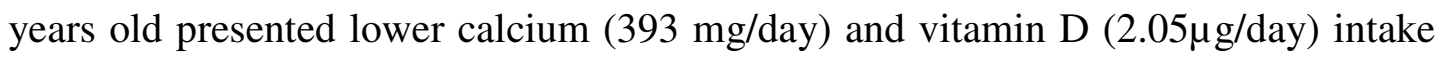
when compared to women in this study [42].

Suppression of secondary hyperparathyroidism by calcium and vitamin D supplementation seems to be of major importance for both muscle and skeletal health. Sorensen et al reported that treatment with cholecalciferol and calcium for $3-$ 6 months could increase in relative fiber composition and in fiber area of type II muscle fibers in muscle biopsies from elderly women [43]. Similary, a study with vitamin D supplementation, and 2-year of follow-up observed that the placebo group presented a further reduction in type II muscle fiber diameter, while in the vitamin D supplemented group, the relative content and mean diameter of type II fibers was increased and the fiber size correlated to 25(OH)D levels [44]. Additionally, intervention study of vitamin D treatment with $800 \mathrm{IU}(20 \mu \mathrm{g})$ per day combined with $1200 \mathrm{mg}$ calcium is reported to reduce secondary hyperparathyroidism, and increase body lean mass after one year in elderly ambulatory women [45].

In a meta-analysis on the efficacy of oral vitamin $d$ supplements for preventing nonvertebral and hip fractures among elderly subjects demonstrated lower risk of nonvertebral fractures (RR 0.86 95\%CI, 0.77-0.96) and 9\% lower risk of hip fractures (RR 0.91 95\%CI, 0.78-1.05). Including all trials, antifracture efficacy increased significantly with a higher dose and higher achieved blood 25hydroxyvitamin D levels for both end points. For the higher dose (> $400 \mathrm{IU} / \mathrm{d})$, the pooled RR was 0.80 (95\% CI, 0.72-0.89; $\mathrm{n}=33265$ subjects from 9 trials) for nonvertebral fractures and $0.82(95 \% \mathrm{CI}, 0.69-0.97 ; \mathrm{n}=31872$ subjects from 5 trials) for hip fractures. It was also observed that the higher dose reduced nonvertebral fractures in community-dwelling individuals (29\%) and institutionalized older individuals (15\%), and its effect was independent of additional calcium supplementation [46].

Considering the combination of calcium and vitamin supplementation on efficacy anti-fracture meta-analysis (17 trials, $n=52$ 625) have shown $12 \%$ of risk reduction of fracture at any skeletal site (RR 0.88, 95\% CI 0.83-0.95; p=0.0004). In trials that reported bone-mineral density as an outcome ( 23 trials, $n=41419$ ), the 
treatment was associated with a reduced rate of bone loss of $0.54 \%(0.35-0.73$; $\mathrm{p}<0.0001)$ at the hip and $1.19 \%(0.76-1.61 \% ; \mathrm{p}<0.0001)$ in the spine. The fracture risk reduction was significantly greater $(24 \%)$ in trials in which the compliance rate was high $(\mathrm{p}<0.0001)$. The treatment effect was better with calcium doses of $1200 \mathrm{mg}$ or more than with doses less than $1200 \mathrm{mg}$ (0.80 vs $0.94 ; \mathrm{p}=0.006)$, and with vitamin D doses of $800 \mathrm{IU}$ or more than with doses less than $800 \mathrm{IU}$ ( 0.84 vs $0.87 ; p=0.03$ ) [47].

Evidence supports the use of vitamin D, or calcium in combination with vitamin D supplementation, for suppressing secondary hyperparathyroidism, and as preventive strategy to minimize muscle and bone loss and also fractures.

With regard to the limitations of the present study, sarcopenia definition did not considered strength, although women with sarcopenia presented significantly lower grip strength when compared to women with no sarcopenia. In addition, the cutoff point used for diagnosing sarcopenia is based in the U.S. population, and more studies are needed to establish different cutoffs for different population.

In conclusion, our results suggest that poor vitamin D status and secondary hyperparathyroidism may have an impact on low muscle mass and bone mass with aging. Besides this study suggests that $25(\mathrm{OH}) \mathrm{D}$ concentrations should be as high as $50 \mathrm{nmol} / \mathrm{L}$ to avoid low muscle and bone mass and combined calcium plus vitamin D supplementation should be considered as the therapeutic for muscle and bone loss. 


\section{References}

1. DeLuca HF. Overview of general physiologic features and functions of vitamin D. Am J Clin Nutr. 2004 Dec;80(6 Suppl):1689S-96S.

2. Bischoff HA, Borchers M, Gudat F, Duermueller U, Theiler R, Stähelin HB, Dick W. In situ detection of 1,25-dihydroxyvitamin D3 receptor in human skeletal muscle tissue. Histochem J. 2001 Jan;33(1):19-24.

3. Suda T, Ueno Y, Fujii K, Shinki T. Vitamin D and bone. J Cell Biochem 2002;88:259-66.

4. Ceglia L. Vitamin D and its role in skeletal muscle. Curr Opin Clin Nutr Metab Care. 2009 Nov;12(6):628-33.

5. Plotnikoff GA, Quigley JM. Prevalence of severe hypovitaminosis D in patients with persistent, nonspecific musculoskeletal pain. Mayo Clin Proc 2003;78:1463-70.

6. Wicherts IS, van Schoor NM, Boeke AJ, et al. Vitamin D status predicts physical performance and its decline in older persons. J Clin Endocrinol Metab 2007;92:2058-65.

7. Dawson-Hughes B. Serum 25-hydroxyvitamin D and functional outcomes in the elderly. Am J Clin Nutr. 2008 Aug;88(2):537S-540S.

8. Brannon PM, Yetley EA, Bailey RL, Picciano MF. Overview of the conference "Vitamin D and Health in the 21st Century: an Update". Am J Clin Nutr. 2008 Aug;88(2):483S-490S.

9. World Health Organization. Physical Status: the use and interpretation of anthropometry. Report. Geneva; 1995. (WHO Technical Report Series, 854).

10. World Health Organization. Study Group on Assessment of fracture risk and its application to screening for postmenopausal osteoporosis. Report. Geneva; 1994. (WHO Technical Report Series, 843).

11. Baumgartner RN, Koehler KM, Gallagher D, Romero L, Heymstleld SB, Ross RR, Garry FJ, Lindeman RD. Epidemiology of sarcopenia among the elderly in New Mexico. Am J Epidemiol, 1998. 147(8):755-63. 
12. Gallagher D, Visser M, De Meersman RE, Sepúlveda D, Baumgartner RN, Pierson RN, Harris T, Heymsfield SB. Appendicular skeletal muscle mass: effects of age, gender, and ethnicity. J Appl Physiol, 1997. 83(1): 229-39.

13. Kallman DA, Plato CC, Tobin JD 1990 The role of muscle loss in the age related decline of grip strength: cross-sectional and longitudinal perspectives. J Gerontol. 1990;45:M82-M88.

14. Harkonen R, Harju R, Alaranta H. Accuracy of the Jamar dynamometer. J Hand Ther 1993;6:259-262.

15. Genant HK, Wu CY, van Kuijk C, Nevitt M. Vertebral fracture assessment using a semi-quantitative technique. J Bone Miner Res. 1993; 8(9):1137-48.

16. Standing Committee on the Scientific Evaluation of Dietary Reference Intakes FaNBIoM. Dietary reference intakes for calcium, phosphorus, magnesium, vitamin D and fluoride. Washington, DC: National Academy Press, 1997.

17. Holick MF. Vitamin D Status: Measurement, Interpretation, and Clinical Application. Ann Epidemiol 2009;19:73-78.

18. World Health Organization. Global strategy on diet, physical activity and health. Geneva; 2004. (Fifty-Seventh World Health Assembly, WHA57.17).

19. Pate RR, Pratt M, Blair SN, Haskell WL, Macera CA, Bouchard C, Buchner D, Ettinger W, Heath GW, King AC, et al. Physical activity and public health: a recommendation from the centers for disease control and prevention and the American College of Sports Medicine. JAMA. 1995;273:402-07.

20. Pluijm SM, Smit JH, Tromp EA, Stel VS, Deeg DJ,Bouter LM, et al. A risk profile for identifying community-dwelling elderly with a high risk of recurrent falling: results of a 3-year prospective study.Osteoporos Int 2006; 17:417-25.

21. Mosekilde L, Hermann AP, Beck-Nielsen H, Charles P, Nielsen SP, Sorensen OH. The Danish Osteoporosis Prevention Study (DOPS): project design and inclusion of 2016 normal perimenopausal women. Maturitas. 1999;31, 207-209. 
22. Lips P. Vitamin D deficiency and secondary hyperparathyroidism in the elderly: consequences for bone loss and fractures and therapeutic implications. Endocr Rev 2001; 22:477-501.

23. Visser M, Deeg D, Lips P. Low vitamin D and high parathyroid hormone levels as determinants of loss of muscle strength and muscle mass (sarcopenia): the longitudinal aging study Amsterdam. J Clin Endocrinol Metab 2003: 88: 57665772 .

24. Deutch S, Jesen MB, Chritiansen PM, Hessov I. muscular Performance and Fatigue in Primary Hyperparathyroidism. World J Surg. 2000;24:102-07.

25. Chapuy MC, Preziosi P, Maamer M, Arnaud S, Galan P, Hercberg S, Meunier PJ. Prevalence of vitamin D insufficiency in an adult normal population. Osteoporos Int. 1997; 7:439-443.

26. Vieth R, Ladak Y, Walfish PG. Age-related changes in the 25-hydroxyvitamin D versus parathyroid hormone relationship suggest a different reason why older adults require more vitamin D. J Clin Endocrinol Metab. 2003 Jan;88(1):18591.

27. Bruce DG, St. John A, Nicklason F, Goldswain RT. Secondary hyperparathyroidism in patients from Western Australia with hip fracture: relationship to type of hip fracture, renal function, and vitamin D deficiency. J Am Geriatr Soc. 1999;47:354-359.

28. Lamberg-Allardt CJ, Outila TA, Kärkkainen MU, Rita HJ, Valsta LM. Vitamin D deficiency and bone health in healthy adults in Finland: could this be a concern in other parts of Europe? J Bone Miner Res. 2001;16(11):2066-73.

29. Ceglia L. Vitamin D and skeletal muscle tissue and function. Mol Aspects Med. 2008 Dec;29(6):407-14.

30. Janssen HCJP, Samson MM, Verhaar HJJ. Vitamin D deficiency, muscle function, and falls in elderly people. Am J Clin Nutr 2002;75:611-5.

31. Pfeifer M, Begerow B, Minne HW. Vitamin D and muscle function. Osteoporos Int 2002;13:187-94. 
32. Boland R. Role of vitamin D in skeletal muscle function. Endocr Rev 1986;7:434-448.

33. Mosekilde L. Vitamin D and the elderly. Clinical Endocrinology. 2005;62, 265281.

34. Bischoff-Ferrari HA, Dietrich T, Orav EJ, et al. Higher 25-hydroxyvitamin D concentrations are associated with better lower-extremity function in both active and inactive persons aged > or 1/460 y. Am J Clin Nutr 2004; 80:752-758.

35. Wicherts IS, van Schoor NM, Boeke AJ, et al. Vitamin D status predicts physical performance and its decline in older persons. J Clin Endocrinol Metab 2007; 92:2058-2065.

36. Dam TT, von Muhlen D, Barrett-Connor EL. Sex-specific association of serum vitamin D levels with physical function in older adults. Osteoporos Int 2009;20:751-760.

37. Bischoff-Ferrari HA, Dietrich T, Orav EJ, Dawson-Hughes B. Positive association between 25-hydroxy vitamin D levels and bone mineral density: a population-based study of younger and older adults. Am J Med. 2004;116:634 9.

38. Jesudason D, Need AG, Horowitz M, O'Loughlin PD, Morris HA, Nordin BE. Relationship between serum 25-hydroxyvitamin D and bone resorption markers in vitamin D insufficiency. Bone. 2002 Nov;31(5):626-30.

39. Sahota O, Masud T, San P, Hosking DJ 1999 Vitamin D insufficiency increases bone turnover markers and enhances bone loss at the hip in patients with established vertebral osteoporosis. Clin Endocrinol (Oxf) 51:217-221.

40. Bruyere O, Malaise O, Neuprez A, Reginster J-Y, WHO Collaborating Center for Public Health. High prevalence of inadequate serum vitamin D levels in osteoporotic European postmenopausal women. In: Abstracts of IOF World Congress on Osteoporosis. 2006. p. S33. P142SA.

41. Lopes JB, Danilevicius CF, Takayama L, Caparbo VF, Scazufca M, Bonfá E, Pereira RMR. Vitamin D insufficiency: A risk factor to vertebral fractures in community-dwelling elderly women. Maturitas. 2009;64:218-222. 
42. Pinheiro MM, Schuch NJ, Genaro PS, Ciconelli RM, Ferraz MB, Martini LA. Nutrient intakes related to osteoporotic fractures in men and women--the Brazilian Osteoporosis Study (BRAZOS). Nutr J. 2009; 29:6.

43. Sorensen $\mathrm{OH}$, Lund B, Saltin B, et al. Myopathy in bone loss of ageing: improvement by treatment with 1 alpha-hydroxycholecalciferol and calcium. Clin Sci (Lond) 1979; 56:157-161.

44. Sato Y, Iwamoto J, Kanoko T, Satoh K. Low-dose vitamin D prevents muscular atrophy and reduces falls and hip fractures in women after stroke: a randomized controlled trial. Cerebrovasc Dis 2005; 20:187-192.

45. Pfeifer M, Begerow B, Minne HW, Abrams C, Nachtigall D, Hansen C. Effects of a short term vitamin $\mathrm{D}$ and calcium supplementation on body sway and secondary hyperparathyroidism in elderly women. J Bone Miner Res. 2000;15:1113-18.

46. Bischoff-Ferrari HA, Willett WC, Wong JB, Stuck AE, Staehelin HB, Orav EJ, Thoma A, Kiel DP, Henschkowski J. Prevention of nonvertebral fractures with oral vitamin D and dose dependency: a meta-analysis of randomized controlled trials.Arch Intern Med. 2009;169(6):551-61.

47. Tang BM, Eslick GD, Nowson C, Smith C, Bensoussan A. Use of calcium or calcium in combination with vitamin D supplementation to prevent fractures and bone loss in people aged 50 years and older: a meta-analysis. Lancet. 2007;370(9588):657-66. 
Table 1. Characteristic of elderly women

\begin{tabular}{|c|c|c|c|c|}
\hline Characteristic & $\begin{array}{c}\text { Total } \\
(\mathrm{n}=105)\end{array}$ & $\begin{array}{c}\text { No sarcopenia } \\
(\mathbf{n}=\mathbf{7 0})\end{array}$ & $\begin{array}{c}\text { Sarcopenia } \\
\quad(n=35)\end{array}$ & $p$ \\
\hline Age (years) & $70.66(5.21)$ & $70.66(4.95)$ & $70.66(5.76)$ & 1.000 \\
\hline Weight (kg) & $54.52(7.66)$ & $55.02(7.24)$ & $53.54(8.46)$ & 0.354 \\
\hline Height $(\mathrm{cm})$ & $149.84(6.01)$ & $149.10(5.68)$ & $151.34(6.43)$ & 0.071 \\
\hline $\operatorname{BMI}\left(\mathrm{kg} / \mathrm{m}^{2}\right)$ & $24.32(3.23)$ & $24.74(2.88)$ & $23.49(3.75)$ & 0.062 \\
\hline \multicolumn{5}{|l|}{ Body Composition } \\
\hline Total Muscle Mass (kg) & $31.07(3.44)$ & $32.16(3.23)$ & $28.90(2.77)$ & $<0.001$ \\
\hline $\operatorname{ASMM}(\mathrm{kg})$ & $13.07(1.98)$ & $13.76(1.74)$ & $11.67(1.69)$ & $<0.001$ \\
\hline SMMI $\left(\mathrm{kg} / \mathrm{m}^{2}\right)$ & $5.80(0.71)$ & $6.18(0.53)$ & $5.06(0.38)$ & $<0.001$ \\
\hline Grip strengh $(\mathrm{kg})$ & $19.66(4.47)$ & $20.44(4.31)$ & $18.11(4.42)$ & 0.011 \\
\hline Fat Mass (kg) & $20.10(5.99)$ & $19.91(5.95)$ & $20.47(6.12)$ & 0.654 \\
\hline Fat mass $(\%)$ & $38.40(7.69)$ & $40.62(7.86)$ & $37.29(7.42)$ & 0.036 \\
\hline BMC total body (g) & $1.810(0.280)$ & $1.825(0.269)$ & $1.778(0.302)$ & 0.418 \\
\hline Total Body BMD $\left(\mathrm{g} / \mathrm{cm}^{2}\right)$ & $0.995(0.882)$ & $0.996(0.896)$ & $0.993(0.873)$ & 0.846 \\
\hline \multicolumn{5}{|l|}{ Bone mass } \\
\hline Spine L1-L4 BMD $\left(\mathrm{g} / \mathrm{cm}^{2}\right)$ & $0.913(0.136)$ & $0.915(0.142)$ & $0.907(0.126)$ & 0.765 \\
\hline Femoral neck BMD $\left(\mathrm{g} / \mathrm{cm}^{2}\right)$ & $0.771(0.097)$ & $0.778(0.999)$ & $0.755(0.091)$ & 0.249 \\
\hline Trochanter BMD (g/cm²) & $0.666(0.113)$ & $0.684(0.115)$ & $0.630(0.102)$ & 0.020 \\
\hline Total femur BMD $\left(\mathrm{g} / \mathrm{cm}^{2}\right)$ & $0.811(0.114)$ & $0.827(0.109)$ & $0.778(0.114)$ & 0.036 \\
\hline \multicolumn{5}{|l|}{ Smoke habits (\%) } \\
\hline Current & 8.6 & 10.0 & 5.7 & 0.042 \\
\hline Past & 24.8 & 31.4 & 11.4 & - \\
\hline Never & 66.7 & 58.6 & 82.9 & - \\
\hline \multicolumn{5}{|l|}{ Chronic desease } \\
\hline Cardiovascular disease* & 61.0 & 40.0 & 60.0 & 0.888 \\
\hline Endocrine and metabolic disease* & 24.8 & 65.7 & 34.3 & 0.110 \\
\hline \multicolumn{5}{|l|}{ Falls $(\%)$} \\
\hline 1 fall past year & 32.4 & 30.0 & 37.1 & 0.883 \\
\hline$>1$ fall last year & 13.3 & 14.3 & 11.4 & 0.685 \\
\hline \multicolumn{5}{|l|}{ Fracture $(\%)$} \\
\hline Vertebral & 14.3 & 10.0 & 22.9 & 0.076 \\
\hline No vertebral & 19.0 & 21.4 & 14.3 & 0.380 \\
\hline \multicolumn{5}{|l|}{ Physical activity (\%) } \\
\hline Active & 60.0 & 61.4 & 57.1 & 0.673 \\
\hline Inactive & 40.0 & 38.6 & 42.9 & - \\
\hline \multicolumn{5}{|c|}{ Calcium and vitamin D supplemet (\%) } \\
\hline Yes & 41.9 & 41.4 & 42.9 & 0.889 \\
\hline No & 58.1 & 58.6 & 57.1 & - \\
\hline
\end{tabular}


Table 2. Dietary intake and biochemical markers of bone metabolism in elderly women.

\begin{tabular}{lcccc}
\hline $\begin{array}{c}\text { Nutrients } \\
\text { Biochemical markers }\end{array}$ & $\begin{array}{c}\text { Total } \\
(\mathbf{n = 1 0 5})\end{array}$ & $\begin{array}{c}\text { No sarcopenia } \\
(\mathbf{n = 7 0})\end{array}$ & $\begin{array}{c}\text { Sarcopenia } \\
(\mathbf{n = 3 5})\end{array}$ & $\boldsymbol{p}$ \\
\hline Dietary intake & & & & \\
Calcium (mg/d) & $624.88(299.81)$ & $599.25(284.66)$ & $676.12(326.28)$ & 0.217 \\
Phosphorus (mg/d) & $936.80(314.10)$ & $924.08(293.47)$ & $962.25(354.95)$ & 0.560 \\
Vitamin D (mcg/d) & $3.21(1.56)$ & $3.33(1.41)$ & $2.97(1.82)$ & 0.261 \\
Biochemichal & & & & \\
25(OH)D (nmol/L) & $49.23(17.82)$ & $50.29(18.24)$ & $47.11(17.02)$ & 0.391 \\
PTH (pg/mL) & $48.82(14.82)$ & $47.55(14.28)$ & $51.36(15.74)$ & 0.216 \\
Albumin $(\mathrm{g} / \mathrm{dL})$ & $4.30(0.52)$ & $4.38(0.56)$ & $4.13(0.40)$ & 0.018 \\
Creatinine (mg/dL) & $0.81(0.20)$ & $0.82(0.17)$ & $0.79(0.25)$ & 0.479 \\
Calcium (mg/dL) & $9.62(1.29)$ & $9.72(1.47)$ & $9.44(0.814)$ & 0.306 \\
Phosphorus (mg/dL) & $3.83(0.65)$ & $3.85(0.66)$ & $3.78(0.62)$ & 0.577 \\
\hline
\end{tabular}


Table 3. Body composition and bone mass according to levels of $25(\mathrm{OH}) \mathrm{D}$ and secondary hyperparathyroidism in elderly women

\begin{tabular}{|c|c|c|c|c|c|c|}
\hline Characteristic & $\begin{array}{c}25(\mathrm{OH}) \mathrm{D} \\
<50 \mathrm{nmol} / \mathrm{L} \\
(\mathrm{n}=61) \\
\end{array}$ & $\begin{array}{c}25(\mathrm{OH}) \mathrm{D} \\
>50 \mathrm{nmol} / \mathrm{L} \\
(\mathrm{n}=44) \\
\end{array}$ & $p$ & $\begin{array}{c}25(\mathrm{OH}) \mathrm{D}<50 \mathrm{nmol} / \mathrm{L} \\
\text { PTH }>65 \mathrm{pg} / \mathrm{mL} \\
(\mathrm{n}=13)\end{array}$ & $\begin{array}{c}25(\mathrm{OH}) \mathrm{D}>50 \mathrm{nmol} / \mathrm{L} \\
\text { PTH }<65 \mathrm{pg} / \mathrm{mL} \\
(\mathrm{n}=41)\end{array}$ & $p$ \\
\hline Age (years) & $70.89(5.42)$ & $70.34(4.94)$ & 0.600 & $72.54(6.34)$ & $70.37(5.02)$ & 0.275 \\
\hline Weight (kg) & $53.59(7.38)$ & $55.81(7.94)$ & 0.144 & $53.26(10.5)$ & $55.68(8.02)$ & 0.458 \\
\hline Height (cm) & $149.16(6.26)$ & $150.79(5.56)$ & 0.171 & $148.46(5.99)$ & $150.43(5.67)$ & 0.307 \\
\hline BMI $\left(\mathrm{kg} / \mathrm{m}^{2}\right)$ & $23.95(3.00)$ & $24.83(3.50)$ & 0.175 & $23.44(3.46)$ & $24.90(3.53)$ & 0.202 \\
\hline \multicolumn{7}{|l|}{ Body Composition } \\
\hline Total Muscle Mass (kg) & $30.30(2.92)$ & $32.14(3.84)$ & 0.007 & $29.70(2.96)$ & $31.84(3.65)$ & 0.043 \\
\hline $\operatorname{ASMM}(\mathrm{kg})$ & $12.71(1.59)$ & $13.55(2.36)$ & 0.031 & $12.17(1.76)$ & $13.34(2.20)$ & 0.062 \\
\hline $\operatorname{SMMI}\left(\mathrm{kg} / \mathrm{m}^{2}\right)$ & $5.67(0.60)$ & $5.98(0.82)$ & 0.030 & $5.51(0.55)$ & $5.92(0.78)$ & 0.043 \\
\hline Grip strengh (kg) & $19.72(4.57)$ & $19.59(4.36)$ & 0.884 & $19.00(4.3)$ & $19.87(4.34)$ & 0.532 \\
\hline Fat mass $(\%)$ & $38.60(8.41)$ & $38.12(6.67)$ & 0.755 & $37.31(11.23)$ & $38.39(6.59)$ & 0.671 \\
\hline Fat mass $(\mathrm{kg})$ & $19.90(5.98)$ & $20.37(6.05)$ & 0.698 & $18.69(7.95)$ & $20.44(6.13)$ & 0.408 \\
\hline Total body BMC (g) & $1.797(0.249)$ & $1.827(0.319)$ & 0.593 & $1.738(0.216)$ & $1.813(0.308)$ & 0.334 \\
\hline Total Body BMD $\left(\mathrm{g} / \mathrm{cm}^{2}\right)$ & $0.995(0.083)$ & $0.995(0.095)$ & 0.990 & $0.996(0.071)$ & $0.996(0.094)$ & 0.992 \\
\hline Spine L1-L4 BMD $\left(\mathrm{g} / \mathrm{cm}^{2}\right)$ & $0.909(0.122)$ & $0.917(0.156)$ & 0.783 & $0.915(0.134)$ & $0.917(0.153)$ & 0.957 \\
\hline Femoral neck BMD $\left(\mathrm{g} / \mathrm{cm}^{2}\right)$ & $0.769(0.092)$ & $0.773(0.104)$ & 0.855 & $0.750(0.101)$ & $0.773(0.104)$ & 0.486 \\
\hline Trochanter BMD (g/cm²) & $0.654(0.102)$ & $0.683(0.127)$ & 0.201 & $0.657(0.110)$ & $0.680(0.127)$ & 0.526 \\
\hline Total femur BMD $\left(\mathrm{g} / \mathrm{cm}^{2}\right)$ & $0.791(0.107)$ & $0.838(0.116)$ & 0.035 & $0.779(0.131)$ & $0.837(0.117)$ & 0.175 \\
\hline
\end{tabular}


Figure 1. Prevalence of secondary hyperparathyroidism in women with and without sarcopenia.

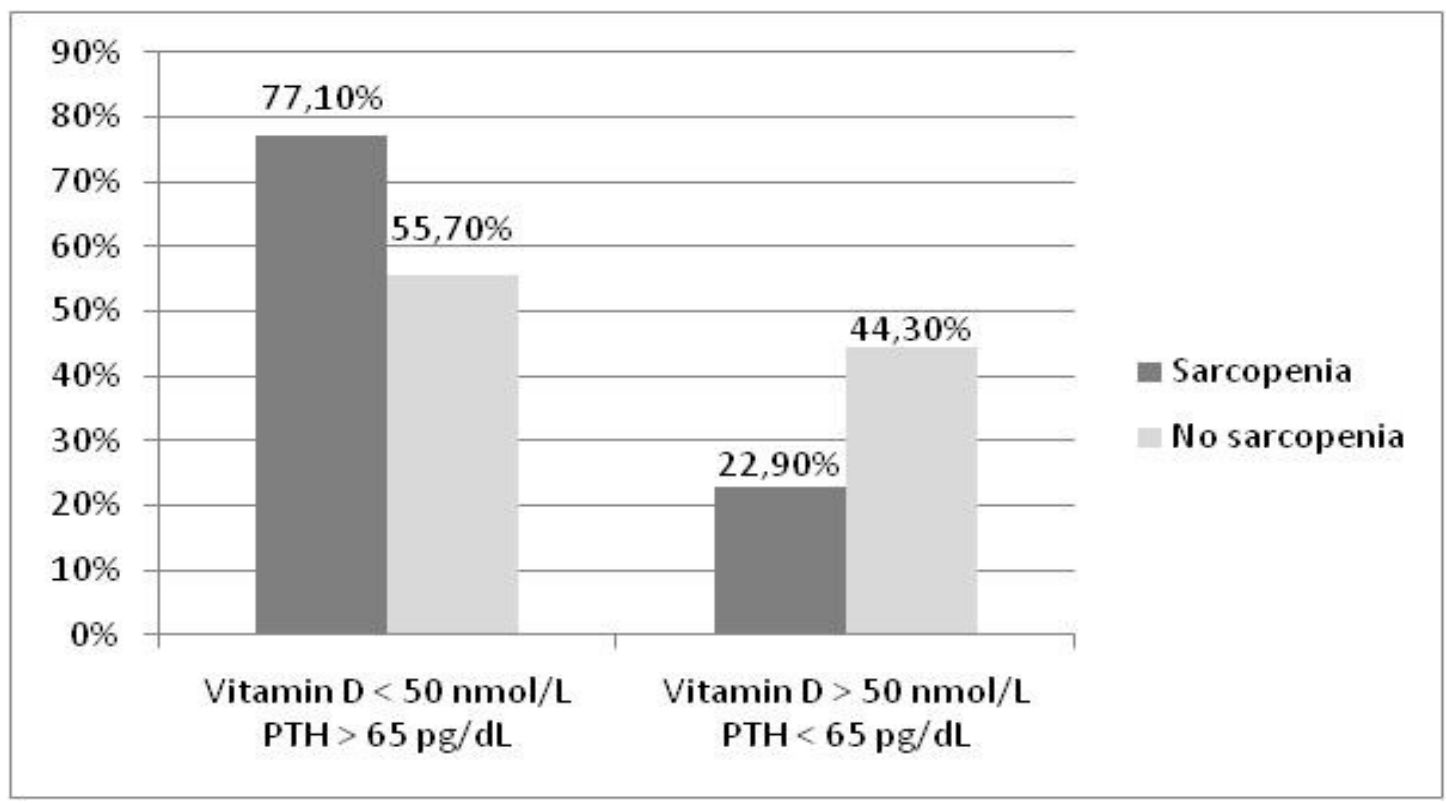




\section{CONSIDERAÇÕES FINAIS}

A deterioração do desempenho musculoesquelético, maior risco de quedas, fraturas, incapacidade, dependência, hospitalização e mortalidade em idosos, particularmente do sexo feminino, estão intimamente associada à redução da massa muscular (sarcopenia). Com o aumento da proporção de idosos na população brasileira, a sarcopenia poderá ter implicações sobre aspectos sociais e econômicos na saúde pública. Desta forma, a melhor compreensão dos mecanismos envolvidos neste fenômeno poderia contribuir para o tratamento e prevenção deste problema.

Existem diversos fatores etiológicos envolvidos com a patogênese da sarcopenia, no aspecto nutricional, a inadequação da ingestão protéica e a deficiência de vitamina $\mathrm{D}$ são fatores importantes e que estão implicados na redução da massa muscular.

O presente estudo observou que tanto massa muscular como a massa óssea se apresentaram aumentas quando o consumo de proteína estava acima de 1,2g/kg/dia. O consumo de aminoácidos essenciais, principalmente os de cadeia ramificada foi significantemente menor em mulheres com sarcopenia. Além disso, o consumo de proteína se associou positivamente com o índice de massa muscular esquelética e a DMO do trocânter.

Além disso, foi observada alta prevalência de sarcopenia na presença de deficiência de vitamina D associada ao PTH elevado (>65pg/dL), hiperparatiroidismo secundário. As mulheres com hiperparatiroidismo secundário apresentaram massa muscular total e índice de massa muscular esquelética significativamente menor. As mulheres com deficiência de vitamina D apresentaram massa muscular total, massa muscular esquelética apendicular, índice de massa muscular esquelética e fêmur total BMD significativamente menor. Concentrações de $25(\mathrm{OH}) \mathrm{D}$ maiores que 50nmol/L parece promover maior massa muscular e óssea.

Como conclusão, a adequação no consumo de proteína, principalmente aminoácidos essências e a suplementação de vitamina D deveriam ser considerados como terapia de prevenção na redução da massa muscular e óssea em mulheres idosas. 


\section{REFERÊNCIAS BIBLIOGRAFICAS}

Aiken J, Bua E, Cao Z, Lopez M, Wanagat J, McKenzie D,McKiernan S. Mitochondrial DNA deletion mutations and sarcopenia. Ann NY Acad Sci. 2002;959:412-23.

Anthony JC, Anthony TG, Kimball SR, Vary TC, Jefferson LS. Orally administered leucine stimulates protein synthesis in skeletal muscle of postabsorptive rats in association with increased eIF4F formation. J Nutr. 2000b; 130:139-45.

Anthony JC, Yoshizawa F, Anthony TG, Vary TC, Jefferson LS, Kimball SR. Leucine stimulates translation initiation in skeletal muscle of postabsorptive rats via a rapamycin-sensitive pathway. J Nutr. 2000a; 130:2413-19.

Anthony TG, Anthony JC, Yoshizawa F, Kimball SR, Jefferson LS. Oral administration of leucine stimulates ribosomal protein mRNA translation but not global rates of protein synthesis in the liver of rats. J Nutr. 2001;131:1171-76.

Bauer JM, Sieber CC. Sarcopenia and frailty: a clinician's controversial point of view. Exp Gerontol. 2008;43:674-8.

Baumgartner RN, Koehler KM, Gallagher D, Romero L, Heymstleld SB, Ross RR, Garry FJ, Lindeman RD. Epidemiology of sarcopenia among the elderly in New Mexico. Am J Epidemiol. 1998;147:755-63.

Bigot A, Jacquemin V, Debacq-Chainiaux F, Butler-Browne GS, Toussaint O, Furling D, Mouly V. Replicative aging down-regulates the myogenic regulatory factors in human myoblasts. Biol Cell. 2008;100:189-99.

Bischoff HA, Borchers M, Gudat F, Duermueller U, Theiler R, Stähelin HB, Dick W. In situ detection of 1,25-dihydroxyvitamin D3 receptor in human skeletal muscle tissue. Histochem J. 2001;33:19-24.

Bischoff HA, Stähelin HB, Dick W, Akos R, Knecht M, Salis C, Nebiker M, Theiler R, Pfeifer M, Begerow B, Lew RA, Conzelmann M. Effects of vitamin D and calcium supplementation on falls: a randomized controlled trial. J Bone Miner Res. 2003;18:343-51. 
Bischoff-Ferrari HA, Borchers M, Gudat F, Dürmüller U, Stähelin HB, Dick W. Vitamin D receptor expression in human muscle tissue decreases with age. J Bone Miner Res. 2004a;19:265-9.

Bischoff-Ferrari HA, Dietrich T, Orav EJ, Hu FB, Zhang Y, Karlson EW, DawsonHughes B. Higher 25-hydroxyvitamin D concentrations are associated with better lower-extremity function in both active and inactive persons aged $>$ or $=60 \mathrm{y}$. Am J Clin Nutr. 2004b;80:752-8.

Bischoff-Ferrari HA, Giovannucci E, Willett WC, Dietrich T, Dawson-Hughes B. Estimation of optimal serum concentrations of 25-hydroxyvitamin D for multiple health outcomes. Am J Clin Nutr. 2006 Jul;84(1):18-28.

Bischoff-Ferrari HA, Willett WC, Wong JB, Giovannucci E, Dietrich T, DawsonHughes B. Fracture prevention with vitamin D supplementation: a meta-analysis of randomized controlled trials. JAMA. 2005;293:2257-64.

Boersheim E, Bui QU, Tissier S, Kobayshi H, Ferrando AA, Wolfe RR. Amino acid supplementation improves muscle mass, strength and physical function in elderly. Clin Nutr. 2008;27:189-95.

Bolland R, de Boland AR, Ritz E, Hasselbach W. Effect of 1,25dihydroxicholecalciferol on sarcoplasmatic reticulum calcium transport in strontium fed rats. Calcif Tissue Int. 1983;35:190.

Bolland R. Role of vitamin D in skeletal muscle function. Endocr Ver. 1986;7:43448.

Brandão, Cynthia M. A; Camargos, Bruno Muzzi; Zerbini, Cristiano Augusto; Plapler, Pérola Grinberg; Mendonça, Laura Maria de Carvalho; Albergaria, BenHur; Pinheiro, Marcelo Medeiros; Prado, Mirley do; Eis, Sergio Ragi. Posições oficiais 2008 da Sociedade Brasileira de Densitometria Clínica (SBDens) / 2008 official positions of the Brazilian Society positions of the Brazilian Society for Clinical Densitometry - SBDens. Arq. bras. endocrinol. metab;53(1):107-112, fev. 2009.

Bua EA, McKiernan SH, Wanagat J, McKenzie D, Aiken JM. Mitochondrial abnormalities are more frequent in muscles undergoing sarcopenia. J Appl Physiol. 2002;92:2617-24. 
Buitrago CG, Ronda AC, de Boland AR, Boland R. MAP kinases p38 and JNK are activated by the steroid hormone 1alpha,25(OH)2-vitamin D3 in the C2C12 muscle cell line. J Cell Biochem. 2006;97:698-708.

Campbell WW, Trappe TA, Wolfe RR, Evans WJ. The recommended dietary allowance for protein may not be adequate for older people to maintain skeletal muscle. J Gerontol A Biol Sci Med Sci. 2001;56:373-80.

Capiati D, Benassati S, Boland RL. 1,25(OH)2-vitamin D3 induces translocation of the vitamin D receptor (VDR) to the plasma membrane in skeletal muscle cells. J Cell Biochem. 2002;86:128-35.

Castillo EM, Goodman-Gruen D, Kritz-Silverstein D, Morton DJ, Wingard DL, Barrett-Connor E. Sarcopenia in Elderly Men and Women The Rancho Bernardo Study. Am J Prev Med. 2003;25:226-31.

Ceglia L. Vitamin D and skeletal muscle tissue and function. Mol Aspects Med. 2008;29:407-14.

Charge SBP and Rudnicki MA. Cellular and Molecular Regulation of Muscle Regeneration Physiol Rev.2004;84:209-38.

Chevalier S, Gougeon R, Nayar K, Morais JA. Frailty amplifies the effects of aging on protein metabolism: role of protein intake. Am J Clin Nutr. 2003;78:422-9.

Conboy IM, Conboy MJ, Smythe GM, Rando TA. Notchmediated restoration of regenerative potential to aged muscle. Science. 2003;302:1575-77.

Deschenes MR. Effects of aging on muscle fibre type and size. Sports Medicine. 2004;34: 809-824.

Dhesi JK, Jackson SH, Bearne LM, Moniz C, Hurley MV, Swift CG, Allain TJ. Vitamin D supplementation improves neuromuscular function in older people who fall. Age Ageing. 2004;33:589-95.

Dirks AJ, Hofer T, Marzetti E, Pahor M, Leeuwenburgh C. Mitochondrial DNA mutations, energy metabolism and apoptosis in aging muscle. Ageing Res Rev. 2006;5:179-195.

Doherty TJ. Invited review: Aging and sarcopenia. J Appl Physiol. 2003;95: 171727.

Dorrens $\mathbf{J}$ and Rennie MJ. Effects of ageing and human whole body and muscle protein turnover. Scand J Med Sci Sports. 2003;13:26-33. 
Dreyer HC, Blanco CE, Sattler FR, Schroeder ET, Wiswell RA. Satellite cell numbers in young and older men 24 hours after eccentric exercise. Muscle Nerve. 2006;33:242-53.

Drittanti L, de Boland AR, Boland R. Stimulation of calmodulin synthesis in proliferating myoblasts by 1,25-dihydroxy-vitamin D3. Mol Cell Endocrinol. 1990;74:143-53.

Dupont-Versteegden EE. Apoptosis in muscle atrophy: relevance to sarcopenia. Exp Gerontol. 2005;40:473-81.

Edström E, Altun M, Bergman E, Johnson H, Kullberg S, Ramírez-León V, Ulfhake B. Factors contributing to neuromuscular impairment and sarcopenia during aging. Physiol Behav. 2007;92:129-35.

Endo I, Inoue D, Mitsui T, Umaki Y, Akaike M, Yoshizawa T, Kato S, Matsumoto T. Deletion of vitamin D receptor gene in mice results in abnormal skeletal muscle development with deregulated expression of myoregulatory transcription factors. Endocrinology 2003;144:5138-44.

Fisberg RM. A qualidade da dieta e seus fatores associados em adultos residentes no estado de São Paulo. São Paulo; 2005. [Tese de Livre Docência - Faculdade de Saúde Pública da USP].

Fisher AL. Of worms and women: sarcopenia and its role in disability and mortality. J Am Geriatr Soc. 2004;52:1185-90.

Flicker L, MacInnis RJ, Stein MS, Scherer SC, Mead KE, Nowson CA, Thomas J, Lowndes C, Hopper JL, Wark JD. Should older people in residential care receive vitamin D to prevent falls? Results of a randomized trial. J Am Geriatr Soc. 2005;53:1881-8.

Frassetto LA, Lanham-New SA, Macdonald HM, Remer T, Sebastian A, Tucker KL, Tylavsky FA. Standardizing terminology for estimating the diet-dependent net acid load to the metabolic system. J Nutr. 2007;137:1491-2. 
Frontera WR, Hughes VA, Lutz KJ, Evans WJ. A cross sectional study of muscle strength and mass in 45 to 78-yr-old men and women. J Appl Phys. 1991;71:64450.

Fujita S, Dreyer HC, Drummond MJ, Glynn EL, Cadenas JG, Yoshizawa F, Volpi E, Rasmussen BB. Nutrient signalling in the regulation of human muscle protein synthesis. J Physiol. 2007;582:813-23.

Fulle S, Protasi F, Di Tano G, Pietrangelo T, Beltramin A, Boncompagni S, Vecchiet L, Fanò G. The contribution of reactive oxygen species to sarcopenia and muscle ageing. Exp Gerontol. 2004;39:17-24.

Gallagher D, Visser M, De Meersman RE, Sepúlveda D, Baumgartner RN, Pierson RN, Harris T, Heymsfield SB. Appendicular skeletal muscle mass: effects of age, gender, and ethnicity. J Appl Physiol, 1997;83: 229-39.

Gallegly JC, Turesky NA, Strotman BA, Gurley CM, Peterson CA, DupontVersteegden EE. Satellite cell regulation of muscle mass is altered at old age. J Appl Physiol. 2004;97:1082-90.

Garlick PJ. The role of leucine in the regulation of protein metabolism. J Nutr. 2005; $135: 1553-56$.

Genant HK, Wu CY, van Kuijk C, Nevitt M. Vertebral fracture assessment using a semi-quantitative technique. J Bone Miner Res. 1993; 8:1137-48.

Gillette-Guyonnet S, Nourhasshemi F, Andrieu S, Cantet C, Albarede JL, Vellas B, Grandjean H. Body Composition in French women 75+ years of age: the EPIDOS study. Mech Aging Dev. 2003;124:311-16. 
Giuliani DL, Boland RL. Effects of vitamin D3 metabolites on calcium fluxes in intact chicken skeletal muscle and myoblasts cultured in vitro. Calcif Tissue Int. 1984;36:200-5.

Harkonen R, Harju R, Alaranta H. Accuracy of the Jamar dynamometer. J Hand Ther 1993;6:259-262.

Herbst A, Pak JW, McKenzie D, Bua E, Bassiouni M, Aiken JM. Accumulation of mitochondrial DNA deletion mutations in aged muscle fibers: evidence for a causal role in muscle fiber loss. J Gerontol Ser A Biol Sci Med Sci. 2007;62:23545 .

Hiona A, Leeuwenburgh C. The role of mitochondrial DNA mutations in aging and sarcopenia: implications for the mitochondrial vicious cycle theory of aging. Exp Gerontol. 2008;43:24-3.

Houston DK, Nicklas BJ, Ding J, Harris TB, Tylavsky FA, Newman AB, Lee JS, Sahyoun NR, Visser M, Kritchevsky SB. Dietary protein intake is associated with lean mass change in older, community-dwelling adults: the Health, Aging and Body Composition (Health ABC) Study. Am J Clin Nutr. 2008;87:150-5.

Iannuzzi-Sucich M, Prestwood KM, Kenny AM. Prevalence of sarcopenia and predictors of skeletal muscle mass in healthy, older men and women. J Gerontol A Biol Sci Med Sci. 2002;57:772-77.

Janssen I, Heymsfield SB, Wang ZM, Ross R. Skeletal muscle mass and distribution in 468 men and women aged 18-88 yr. J Appl Physiol. 2000;89:81-8.

Janssen I, Shepard DS, Katzmarzyk PT, Roubenoff R. The Healthcare Costs of Sarcopenia in the United States. J Am Geriatr Soc. 2004;52:80-5.

Katsanos CS, Kobayashi H, Sheffield-Moore M, Aarsland A, Wolfe RR. A high proportion of leucine is required for optimal stimulation of the rate of muscle protein synthesis by essential amino acids in the elderly. Am J Physiol Endocrinol Metab. 2006; 291:381-87.

Kimball S, Fuleihan Gel-H, Vieth R. Vitamin D: a growing perspective. Crit Rev Clin Lab Sci. 2008;45:339-414.

Lang T, Streeper T, Cawthon P, Baldwin K, Taaffe DR, Harris TB. Sarcopenia: etiology, clinical consequences, intervention, and assessment. Osteoporos Int. 2009 Sep 25. [Epub ahead of print]. 
Lau EM, Lynn HS, Woo JW, Kwok TC, Melton L.J.3 ${ }^{\text {rd }}$. Prevalence of and risk factors for sarcopenia in elderly Chinese men and women. J Gerontol A Biol Sci Med Sci. 2005;60:213-6.

Lauretani F, Bandinelli S, Bartali B, Di Iorio A, Giacomini V, Corsi AM, Guralnik JM, Ferrucci L. Axonal degeneration affects muscle density in older men and women. Neurobiol Aging. 2006;27:1145-54.

Levine DM, Berenson ML, Stephan D. Estatística: Teoria e Aplicações usando Microsoft Excel em Português. Rio de Janeiro: LTC; 2000.

Lexell J, Downham DY: What determines the muscle crosssectional area? J Neurol Sci. 1992;111:113-14.

Looker AC, Wahner HW, Dunn WL2, Calvo MS, Harris TB, Heyse SP, Johnston Jr CC, Lindsay R. Updated Data on Proximal Femur Bone Mineral Levels of US Adults. Osteoporos Int. 1998;8:468-489.

Lord C, Chaput JP, Aubertin-Leheudre M, Labonté M, Dionne IJ. Dietary animal protein intake: association with muscle mass index in older women. J Nutr Health Aging. 2007;11:383-7.

Marinissen MJ, Selles J, Boland R. Involvement of protein kinase C in 1,25(OH)2vitamin D3 regulation of calcium uptake by cultured myocytes. Cell Signal. $1994 ; 6: 531-8$.

Marzetti E and Leeuwenburgh C. Skeletal muscle apoptosis, sarcopenia and frailty at old age. Exp Gerontol, 2006;41:1234-8.

McComas AJ. ISEK Congress Keynote Lecture: Motor units: how many, howlarge, what kind? International Society of Electrophysiology and Kinesiology. J Electromyogr Kinesiol, 1998;8:391-402.

McCroskery S, Thomas M, Maxwell L, Sharma M, Kambadur R. Myostatin negatively regulates satellite cell activation and self-renewal. J Cell Biol. 2003; 162:1135-47.

Melton LJ 3rd, Khosla S, Crowson CS, O'Connor MK, O'Fallon WM, Riggs BL. Epidemiology of sarcopenia. J Am Geriatr Soc. 2000;48:625-30.

Morais JA, Chevalier S, Gougeon R. Protein turnover and requirements in the healthy and frail elderly. J Nutr Health Aging. 2006;10:272- 83. 
Morley JE, Baumgartner RN, Roubenoff R , Mayer J, Nair KS. Sarcopenia. J Lab Clin Med. 2001;137:231-43.

Paddon-Jones D, Rasmussen BB. Dietary protein recommendations and the prevention of sarcopenia. Curr Opin Clin Nutr Metab Care. 2009;12:86-90.

Paddon-Jones D, Sheffield-Moore M, Katsanos CS, Zhang XJ, Wolfe RR. Differential stimulation of muscle protein synthesis in elderly humans following isocaloric ingestion of amino acids or whey protein. Exp Gerontol. 2006;41:21519.

Pannemans DL, Wagenmakers AJ, Westerterp KR, Schaafsma G, Halliday D.Effect of protein source and quantity on protein metabolism in elderly women. Am J Clin Nutr. 1998;68:1228-35.

Pate RR, Pratt M, Blair SN, Haskell WL, Macera CA, Bouchard C, Buchner D, Ettinger W, Heath GW, King AC, et al. Physical activity and public health: a recommendation from the centers for disease control and prevention and the American College of Sports Medicine. JAMA. 1995;273:402-07.

Pfeifer M, Begerow B, Minne HW, Abrams C, Nachtigall D, Hansen C. Effects of a short-term vitamin D and calcium supplementation on body sway and secondary hyperparathyroidism in elderly women. J Bone Miner Res. 2000;15:1113-8.

Reid MB. Nitric oxide, reactive oxygen species, and skeletal muscle contraction. Med Sci Sports Exerc. 2001;33:371-6.

Rolland Y, Czerwinski S, Abellan Van Kan G, Morley JE, Cesari M, Onder G, Woo J, Baumgartner R, Pillard F, Boirie Y, Chumlea WM, Vellas B. Sarcopenia: its assessment, etiology, pathogenesis, consequences and future perspectives. J Nutr Health Aging. 2008;12:433-50.

Rosenberg IH. Sarcopenia: origins and clinical relevance. J Nutr. 1997;127:990-91.

Sato Y, Inose M, Higuchi I, Higuchi F, Kondo I. Changes in the supporting muscles of the fractured hip in elderly women. Bone. 2002;30:325-30.

Sayer AA, Syddall H, Martin H, Patel H, Baylis D, Cooper C. The developmental origins of sarcopenia. J Nutr Health Aging. 2008;12:427-32.

Sayer AA, Syddall HE, Martin HJ, Dennison EM, Anderson FH, Cooper C. Falls, sarcopenia, and growth in early life: findings from the Hertfordshire cohort study. Am J Epidemiol. 2006;164:665-71. 
Snijder MB, van Schoor NM, Pluijm SM, van Dam RM, Visser M, Lips P. Vitamin D status in relation to one-year risk of recurrent falling in older men and women. $\mathrm{J}$ Clin Endocrinol Metab. 2006;91:2980-5.

Standing Committee on the Scientific Evaluation of Dietary Reference Intake, Food and nutrition Board, Institute of Medicine. Dietary reference intake for Energy, carbohydrate, fiber, fat, protein and acids (macronutrient). Washington, DC: National Academy Press; 2002.

Symons TB, Schutzler SE, Cocke TL, Chinkes DL, Wolfe RR, Paddon-Jones D. Aging does not impair the anabolic response to a protein-rich meal. Am J Clin Nutr. 2007;86:451-6.

Symons TB, Sheffield-Moore M, Wolfe RR, Paddon-Jones D. A moderate serving of high-quality protein maximally stimulates skeletal muscle protein synthesis in young and elderly subjects. J Am Diet Assoc. 2009;109:1582-6.

Szejnfeld VL, Atra E, Baracat EC, Aldrighi JM, Civitelli R. Bone density in white Brazilian women rapid loss at time around the menopause. Calcif Tissue Int. 1995;56:186-91.

Timmerman K and Elena Volpi E. Amino acid metabolism and regulatory effects in aging. Curr Opin Clin Nutr Metab Care. 2008;11:45-9.

Tipton KD, Elliott TA, Cree MG, Wolf SE, Sanford AP, Wolfe RR. Ingestion of casein and whey proteins result in muscle anabolism after resistance exercise. Med Sci Sports Exerc. 2004;36:2073-81.

Topinková E. Aging, disability and frailty. Ann Nutr Metab. 2008;52:6-11.

Veras R. Population aging today: demands, challenges and innovations. Rev Saude Publica. 2009;43:548-54.

Verdijk LB, Koopman R, Schaart G, Meijer K, Savelberg HH, van Loon LJ. Satellite cell content is specifically reduced in type II skeletal muscle fibers in the elderly. Am J Physiol Endocrinol Metab. 2007;292:151-57.

Visser M, Deeg DJ, Lips P; Longitudinal Aging Study Amsterdam. Low vitamin D and high parathyroid hormone levels as determinants of loss of muscle strength and muscle mass (sarcopenia): the Longitudinal Aging Study Amsterdam. J Clin Endocrinol Metab. 2003;88:5766-72. 
Volpi E, Kobayashi H, Sheffield-Moore M, Mittendorfer B, Wolfe RR. Essential amino acids are primarily responsible for the amino acid stimulation of muscle protein anabolism in healthy elderly adults. Am J Clin Nutr 2003;78:250-58.

Walrand $\mathrm{S}$ and Boirie Y. Optimizing protein intake in aging. Curr Opin Clin Nutr Metab Care. 2005;8:89-94.

Waters DL, Brooks WM, Qualls CR, Baumgartner RN. Skeletal muscle mitochondrial function and lean body mass in healthy exercising elderly. Mech Ageing Dev. 2003;24:301-9.

Whitman SA, Wacker MJ, Richmond SR, Godard MP. Contributions of the ubiquitin-proteasome pathway and apoptosis to human skeletal muscle wasting with age. Pflugers Arch. 2005;450:437-46.

Willet W, Stampfer M. Implications of totl energy intake for epidemiological analyses. In: Willet W. Nutritional epidemiology. 2nd ed. New York: Oxford University Press; 1998.

Wolfe RR and Miller SL. The recommended dietary allowance of protein: a misunderstood concept. Jama. 2008;299:2891-93.

World Health Organization. Study Group on Assessment of fracture risk and its application to screening for postmenopausal osteoporosis. Report. Geneva; 1994. (WHO Technical Report Series, 843).

World Health Organization. Physical Status: the use and interpretation of anthropometry. Report. Geneva; 1995. (WHO Technical Report Series, 854).

World Health Organization. Global strategy on diet, physical activity and health. Geneva; 2004. (Fifty-Seventh World Health Assembly).

Zanello SB, Collins ED, Marinissen MJ, Norman AW, Boland RL. Vitamin D receptor expression in chicken muscle tissue and cultured myoblasts. Horm Metab Res. 1997;29:231-6. 


\section{ANEXOS}

ANEXO I - Termo de consentimento livre e esclarecido

TERMO DE CONSENTIMENTO LIVRE E ESCLARECIDO

I - DADOS DE IDENTIFICAÇÃO DO SUJEITO DA PESQUISA OU RESPONSÁVEL LEGAL

1. Dados de identificação

Nome do Paciente:

Documento de Identidade $\mathrm{N}^{\circ}$ : Sexo: ( ) M ( ) F

Data de Nascimento: 1 $\mathrm{N}^{\mathrm{o}}$ : Apto:

Endereço: Cidade:

Bairro: Telefone:

CEP: Sexo: ( ) M ( ) F Documento de Identidade $\mathrm{N}^{\circ}$ : I

Data de Nascimento: 1

Endereço: $\mathrm{N}^{\mathrm{o}}$ : Apto:

Bairro: Cidade:

CEP: Telefone:

II - DADOS SOBRE A PESQUISA

1. Título do Protocolo de Pesquisa: Associação entre sarcopenia, nível sérico de vitamina $\mathrm{D}$, capacidade funcional e consumo alimentar de mulheres idosas com osteoporose.

Pesquisador: Patrícia de Souza Genaro

Documento de Identidade: SP- 28.702.659-0 Sexo: F

Cargo/Função: Nutricionista, aluna de doutorado 
Departamento de Nutrição da Faculdade de Saúde Pública da Universidade de São Paulo

2. Avaliação do risco da pesquisa: risco mínimo, considerando a realização da coleta de sangue $(10 \mathrm{ml})$, da densitometria e do raio $\mathrm{X}$. A coleta de sangue será realizada com materiais descartáveis e por enfermeiros do Laboratório Central da UNIFESP após 12 horas de jejum. O procedimento pode ocasionar desconforto leve e hematoma no local na picada. A densitometria não oferece risco ao indivíduo tendo em vista que será realizada por um técnico em radiologia da Disciplina de Reumatologia da UNIFESP, não impede a realização de qualquer atividade física posterior e a sua radiação é 50 vezes menor do que a oferecida em um exame de raio $\mathrm{X}$, tornando a realização desta técnica segura.

3. Duração da pesquisa: 36 meses

\section{III - EXPLICAÇÕES SOBRE A PESQUISA INTRODUÇÃO}

Você está sendo convidada a participar de um estudo de pesquisa que vai investigar a associação entre sarcopenia (falta de massa muscular), nível sérico de vitamina $\mathrm{D}$, capacidade funcional e consumo alimentar.

Antes de tomar uma decisão sobre sua participação neste estudo de pesquisa, é importante que você leia e compreenda a explicação dos procedimentos propostos abaixo. Este termo de consentimento livre e esclarecido descreve a finalidade, os procedimentos, os benefícios, riscos, desconfortos e advertências deste estudo.

\section{FINALIDADE}

A diminuição gradativa da massa e da força muscular que ocorrem com o avanço da idade tem sido associada à deficiência de vitamina $\mathrm{D}$, inadequação no consumo alimentar, limitações na capacidade de exercer atividades diárias e risco de fraturas por quedas. Deste modo, o presente estudo será realizado.

\section{OBJETIVO}

Este estudo tem como objetivo principal investigar a associação entre sarcopenia, nível sérico de vitamina D, capacidade funcional e consumo alimentar em mulheres 
idosas com osteoporose. A pesquisa terá duração de 4 meses, com participação de 200 voluntárias.

\section{INFORMAÇÕES SOBRE O ESTUDO}

Você receberá um tratamento com nutricionista para melhorar a osteoporose e a falta de massa muscular. Para a visita de inclusão, você terá um exame clínico e questionários (para verificar a possibilidade de sua participação no estudo), além de recomendações para preencher um formulário de registro alimentar de 3 dias. Depois desta triagem, você terá que devolver o formulário de registro alimentar de 3 dias à nutricionsita. Para a realização do projeto serão coletadas as seguintes informações: avaliação da composição corporal (quantidade de gordura e músculos), exames de sangue (cálcio, fósforo, creatinina, PTH, vitamina D), questionário dietético (avaliar a sua alimentação) e questionário sobre sua história clínica e atividades diárias.

\section{IV -ESCLARECIMENTOS SOBRE GARANTIAS DO SUJEITO DA PESQUISA}

\section{Direito de fazer perguntas}

Se você tiver dúvidas sobre este estudo de pesquisa, tiver problemas relacionados ao estudo, ou quiser informações sobre procedimentos, riscos e benefícios relacionados à pesquisa em qualquer momento, você pode entrar em contato com a nutricionista Patrícia de Souza Genaro pelo telefone (12) 8118-2084 ou com a Professora Dra Lígia A. Martini pelo telefone (11) 3061-7705, ramal 228. Para entrar em contato com o comitê de ética da Faculdade de Saúde Pública/USP, o telefone é 3061-7779.

\section{Participação e retirada voluntária do Estudo}

Você é livre para participar do estudo e para interromper sua participação em qualquer momento, sem ter que dar um motivo. Se você decidir se retirar do estudo, você deve simplesmente informar a nutricionista Patrícia de Souza Genaro.

3. Uso de resultados e confidencialidade do estudo

Sua identificação (nome e endereço) será arquivada na instituição onde você será tratada, com a segurança adequada. Se os resultados forem publicados, sua identidade não será revelada. 
V - INFORMAÇÕES PARA CONTATO EM CASO DE INTERCORRÊNCIAS CLÍNICAS E REAÇÕES ADVERSAS

Nome: Patrícia de Souza Genaro

Telefone: (11) 3061-7705 - ramal 228; (12) 8118-2084

Endereço: Av. Dr. Arnaldo, 715, Departamento de Nutrição ( $2^{\circ}$ andar)

Bairro: Cerqueira César Cidade: São Paulo CEP: 01246-904

\section{VI - CONSENTIMENTO PÓS-ESCLARECIDO}

Declaro que, após convenientemente esclarecido pela pesquisadora Patrícia de Souza Genaro e ter entendido o que me foi explicado, consinto em participar do presente Protocolo de Pesquisa.

São Paulo, de de

Assinatura do sujeito da pesquisa ou responsável legal 


\section{ANEXO II - Registro alimentar}

Registro alimentar de 3 dias

Para registro diário das refeições é feito com a finalidade de se obter conhecimentos sobre a alimentação, sendo estas informações de fundamental importância, pois juntamente com outros dados irão auxiliar na sua avaliação nutricional.

\section{OBSERVAÇÕES}

Anotar toda a alimentação ingerida no período de (03) três dias.

Durante cada dia, anotar toda a alimentação, como o que ingeriu de café da manhã, almoço e jantar. Não deixar de anotar as refeições/ lanches intermediários ou qualquer outro tipo de alimentos ingeridos.

Deve ser anotado o tipo e a quantidade do alimento ingerido.

Exemplo:

Café da manhã: Banana - 1 unidade pequena

Leite - 1 xícara cheia

Açúcar - 1 colher de sopa cheia

Pão francês - 1 unidade ou meio pão

Almoço: Arroz refogado (macarrão, batata, etc) - 2 colheres grandes

Feijão - 3 colheres de sopa

Galinha cozida -1 coxa grande +1 peito pequeno

Salada crua - alface -2 folhas + tomate -1 unidade

Jantar ou lanche anotar no esquema sugerido acima.

Não deixar de medir e anotar alimentos como:

- açúcar (usado no café, sucos, refrescos, leite, etc)

- óleo, margarina, manteiga (usado em pães, bolachas, frituras, saladas, etc)

Anotar se a preparação é cozida, frita ou assada. Com ou sem sal.

Anotar a quantidade de líquidos tomados nas 24 horas, café, leite, chá, sucos,

NÃO DEIXAR DE ANOTAR NENHUMA REFEIÇÃO, ATÉ MESMO AS QUE

FOREM FEITAS FORA DE CASA (hospital, restaurantes, casa de parentes e amigos, etc)

As frutas deverão ser classificadas como: média e grande ou fatia/ rodelas finas, médias ou grossas e assim por diante. 
INQUÉRITO NUTRICIONAL - DIÁRIO DE TRÊS DIAS.

NOME:

DATA: DIA DA SEMANA:

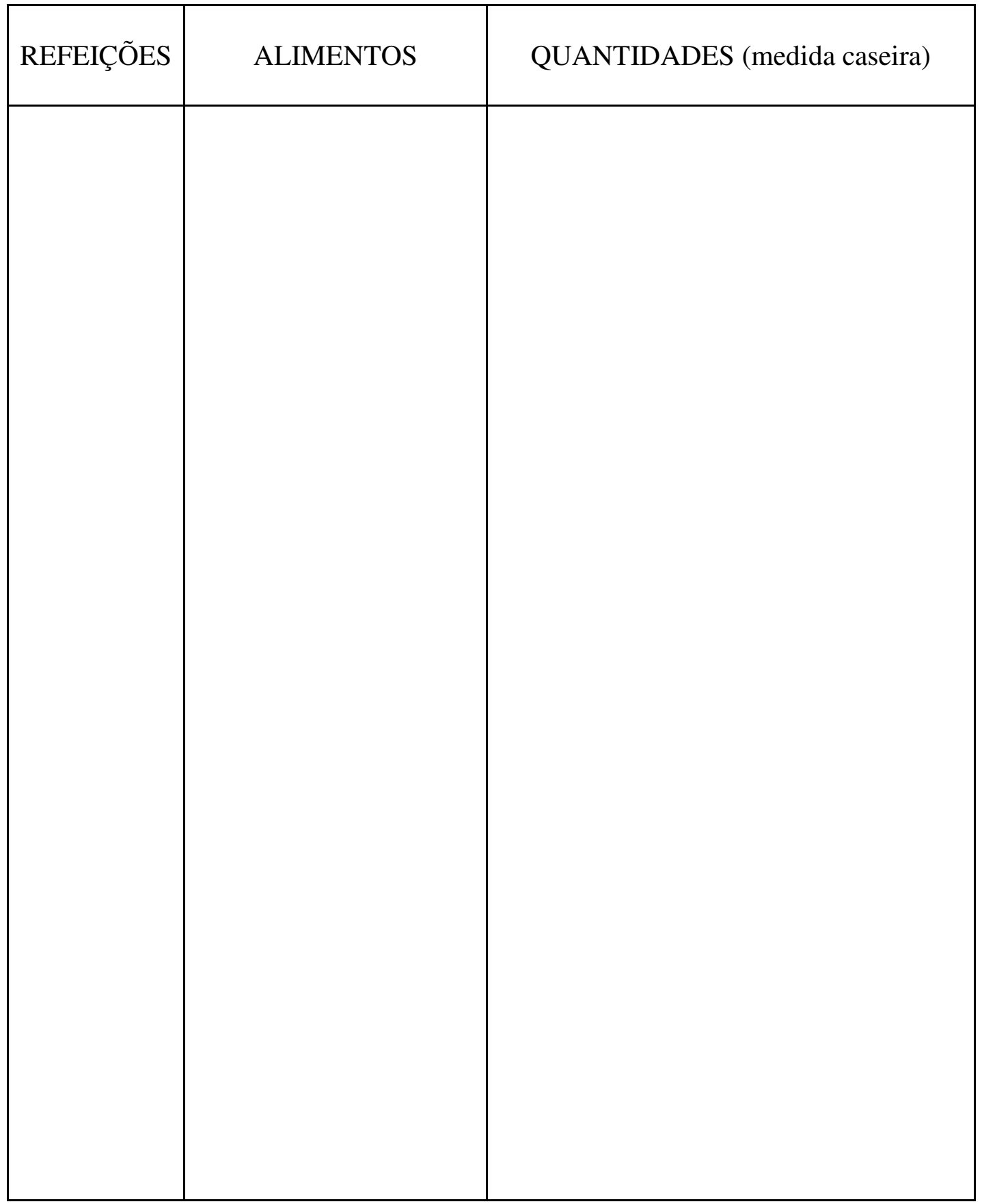


ANEXO III - Protocolo de pesquisa

\section{Protocolo}

Nome:

Fone:

Data de nascimento: Idade:

\section{1 - Dados Ginecológicos:}

- Idade da primeira menstruação? anos

- Idade da última menstruação? anos Número de filhos:

- Você fez cirurgia para retirar o útero?

sim não não sei Idade___ (anos)

- E, para retirar os ovários (um ou os dois)? sim não não sei Idade (anos)

- Você fez reposição hormonal após a menopausa? sim não não sei

- Se sim, quando iniciado, o período foi superior a 1 ano? sim não não sei

\section{2 - Dados familiares:}

- Em sua família (pai, mãe, irmãos) existe história de fratura?

sim não não sei

\section{3- Fumo:}

- Você fumou cigarro ou usou outras formas de fumo (cachimbo ou charuto)? atualmente no passado nunca

- Com que idade iniciou? anos Se parou, com que idade? anos

- Número de cigarros/dia?

\section{4 - Interrogatório sobre drogas:}

- Quais os medicamentos que a Sra. utiliza? 


\section{QUEDAS}

U14. $O$ (a) $\operatorname{Sr}($ a). tem medo de cair?

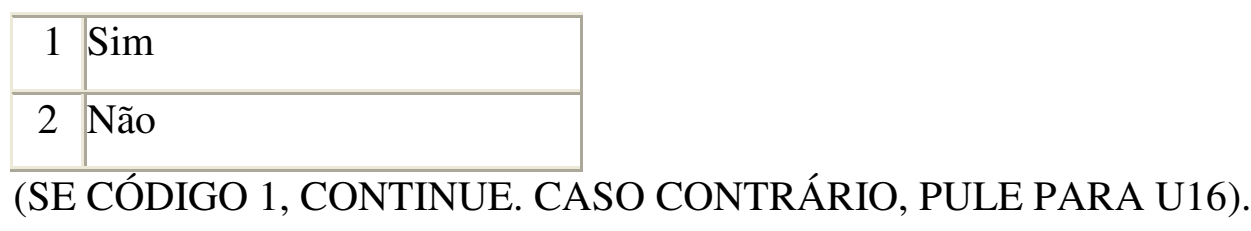

U15. (MOSTRAR CARTÃO U15) Dessas alternativas nesse cartão, o(a) $\operatorname{Sr}($ a) poderia me dizer qual delas é a que melhor ilustra o porquê do seu medo de cair?

\begin{tabular}{|c|l|}
\hline 1 & Medo de fraturar \\
\hline 2 & Medo de se machucar \\
\hline 3 & Outros \\
\hline
\end{tabular}

U16.O(a) $\operatorname{Sr}($ a). caiu no último ano?

\begin{tabular}{|l|l|}
\hline 1 & Sim \\
\hline 2 & Não \\
\hline
\end{tabular}

(SE CÓDIGO 1, CONTINUE. CASO CONTRÁRIO, PULE PARA U19).

U17. Qual o número de vezes que o(a) $\operatorname{Sr}$ (a) caiu exercendo atividades de lazer? E qual o número de vezes que o(a) $\operatorname{Sr}(a)$ caiu exercendo atividades da vida diária?

\section{U17}

Atividades de lazer

I___ I 99 - NS/NÃO LEMBRA

Atividades da vida diária I 99 - NS/NÃO LEMBRA

U18.Onde foi que o(a) Sr(a) caiu? (RESPOSTA MÚLTIPLA)

\begin{tabular}{|c|l|}
\hline 1 & Sala \\
\hline 2 & Banheiro \\
\hline 3 & Quarto \\
\hline 4 & Escada \\
\hline 5 & Calçada \\
\hline 6 & Rua \\
\hline 7 & Quintal \\
\hline 8 & Corredor \\
\hline
\end{tabular}


$\mathbf{U 1 9 . O ( a ) ~} \operatorname{Sr}(a)$. tem tapete na sua casa?

\begin{tabular}{|l|l|}
\hline 1 & Sim \\
\hline 2 & Não \\
\hline
\end{tabular}

U20.Há iluminação adequada nos cômodos que o(a) $\operatorname{Sr}(a)$ utiliza à noite?

\begin{tabular}{|l|l|}
\hline 1 & Sim \\
\hline 2 & Não \\
\hline
\end{tabular}

U21.Há escadas em sua casa?

\begin{tabular}{|l|l|}
\hline 1 & Sim \\
\hline 2 & Não \\
\hline
\end{tabular}

(ATENÇÃO ENTREVISTADOR: SE O RESPONDENTE MENCIONAR Código 1 NA U21, CONTINUE. CASO CONTRÁRIO, PULE PARA U24)

U22.Existe corrimão na escada?

\begin{tabular}{|l|l|}
\hline 1 & Sim \\
\hline 2 & Não \\
\hline
\end{tabular}

U23.Há piso anti-derrapante na escada?

\begin{tabular}{|l|l|}
\hline 1 & Sim \\
\hline 2 & Não \\
\hline
\end{tabular}

U24. Qual o meio de transporte o(a) $\operatorname{Sr}$ (a) utiliza normalmente? (RESPOSTA MÚLTIPLA)

\begin{tabular}{|l|l|}
\hline 1 & Carro \\
\hline 2 & Ônibus \\
\hline 3 & Metrô \\
\hline 4 & Trem \\
\hline 5 & Barco \\
\hline 6 & Bicicleta \\
\hline 7 & Avião \\
\hline
\end{tabular}


U25.Qual o tipo de calçado o(a) Sr(a) utiliza? (RESPOSTA MÚLTIPLA)

\begin{tabular}{|r|l|}
\hline 1 & Borracha \\
\hline 2 & Couro \\
\hline 3 & Chinelo \\
\hline 4 & Salto \\
\hline 5 & Outros \\
\hline
\end{tabular}

U26.O(a) $\operatorname{Sr}$ (a) usa bengala?

\begin{tabular}{|l|l|}
\hline 1 & Sim \\
\hline 2 & Não \\
\hline
\end{tabular}

U27.O(a) Sr(a) tem tonturas?

\begin{tabular}{|l|l|}
\hline 1 & Sim \\
\hline 2 & Não \\
\hline
\end{tabular}

U28.O(a) Sr(a) enxerga bem?

\begin{tabular}{|l|l|}
\hline 1 & Sim \\
\hline 2 & Não \\
\hline
\end{tabular}

U29.O(a) Sr(a) ouve bem?

\begin{tabular}{|l|l|}
\hline 1 & Sim \\
\hline 2 & Não \\
\hline
\end{tabular}

U30.O(a) Sr(a) consegue levantar de uma cadeira sem a ajuda dos braços?

\begin{tabular}{|l|l|}
\hline 1 & Sim \\
\hline 2 & Não \\
\hline
\end{tabular}


Atividades Básicas da Vida Diária (AVD)

\begin{tabular}{|c|c|c|c|}
\hline Atividade & & Sim & Não \\
\hline 1. Banho & $\begin{array}{l}\text { Não recebe ajuda ou somente recebe ajuda para uma } \\
\text { parte do corpo. }\end{array}$ & & \\
\hline 2. Vestir-se & $\begin{array}{l}\text { Pega as roupas e se veste sem qualquer ajuda, exceto } \\
\text { para amarrar os sapatos. }\end{array}$ & & \\
\hline 3. Hig. Pessoal & $\begin{array}{l}\text { Vai e usa o banheiro, veste-se e retorna sem qq ajuda } \\
\text { (andador ou bengala). }\end{array}$ & & \\
\hline 4. Transferência & $\begin{array}{l}\text { Consegue deitar na cama, sentar na cadeira e } \\
\text { levantar-se sem ajuda (andador ou bengala). }\end{array}$ & & \\
\hline 5. Continência & Controla completamente urina e fezes & & \\
\hline 6. Alimentação & $\begin{array}{l}\text { Come sem ajuda (exceto } \mathrm{p} / \text { cortar carne e passar } \\
\text { manteiga no pão). }\end{array}$ & & \\
\hline
\end{tabular}

SCORE:

Somatória Sim: 6 - Independência 4 - Dependência parcial 2 - Dependência importante

Atividades Instrumentais da Vida Diária (AIVD)

\begin{tabular}{|l|l|l|l|}
\hline & $\begin{array}{c}\text { Sem } \\
\text { ajuda 3 }\end{array}$ & $\begin{array}{c}\text { Com } \\
\text { ajuda } \\
\text { parcial } \\
\mathbf{2}\end{array}$ & $\begin{array}{c}\text { Não } \\
\text { consegue } \\
\mathbf{1}\end{array}$ \\
\hline 1. Consegue usar o telefone? & & & \\
\hline $\begin{array}{l}\text { 2. Consegue ir a lugar distante, usando algum tipo de } \\
\text { transporte, sem necessidade de planejamentos especiais? }\end{array}$ & & & \\
\hline 3. Consegue fazer compras? & & & \\
\hline 4. Consegue preparar suas próprias refeições? & & & \\
\hline 5. Consegue arrumar a cama? & & & \\
\hline $\begin{array}{l}\text { 6. Consegue fazer pequenos trabalhos manuais domésticos, } \\
\text { como pequenos reparos? }\end{array}$ & & & \\
\hline 7. Consegue lavar e passar sua roupa? & & & \\
\hline $\begin{array}{l}\text { 8. Consegue tomar seus remédios na dose certa e horário } \\
\text { correto? }\end{array}$ & & & \\
\hline 9. Consegue cuidar de suas finanças? & & & \\
\hline SCORE: & & & \\
\hline
\end{tabular}

SCORE:

9 - Totalmente dependente; 10 a 15 - Dependência grave; 16 a 20 - Dependência moderada; 21 a 25 - Dependência leve; 26 a 27 - Independência 


\section{Atividade física}

1. Nos últimos três meses, o(a) sr(a) praticou algum tipo de exercício físico ou esporte?

$\square \operatorname{sim}$

$\square$ não (pule para q7)

2. Qual o tipo principal de exercício físico ou esporte que o (a) $\operatorname{sr}(a)$ praticou? Anotar apenas o primeiro citado.

$\square$ caminhada (não vale deslocamento para o trabalho)

$\square$ caminhada com esteira (pule para a questão 4)

$\square$ corrida (pule para a questão 4)

$\square$ corrida em esteira (pule para a questão 4)

$\square$ musculação (pule para a questão 4)

$\square$ ginástica aeróbica (pule para a questão 4)

$\square$ hidroginástica (pule para a questão 4 )

$\square$ ginástica em geral (pule para a questão 4)

$\square$ natação (pule para a questão 4)

$\square$ artes marciais e lutas (pule para a questão 4)

$\square$ bicicleta (pule para a questão 4)

$\square$ futebol (pule para a questão 4)

$\square$ basquetebol (pule para a questão 4)

$\square$ voleibol (pule para a questão 4 )

$\square$ tênis (pule para a questão 4)

$\square$ outros (pule para a questão 4 )

3. Quando o (a) sr(a) faz caminhada, sua respiração costuma ficar:

( ) igual a de sempre

( ) um pouco aumentada

$\square$ não sabe

4. $\mathrm{O}$ (a) sr(a) pratica exercício pelo menos uma vez por semana?

$\square \operatorname{sim}$

$\square$ não - (pule para q7)

5. Quantos dias por semana o(a) sr(a) costuma praticar esporte ou exercício?

( ) todos os dias

( ) 5 a 6 dias por semana

( ) 3 a 4 dias por semana

( ) 1 a 2 dias por semana 
6. No dia que o(a) sr(a) pratica exercício ou esporte, quanto tempo dura esta atividade?

( ) menos que 10 minutos

( ) entre 10 e 19 minutos

( ) entre 20 e 29 minutos

( ) entre 30 e 39 minutos

( ) entre 45 e 59 minutos

( ) 60 minutos ou mais

7. Nos últimos três meses, o(a) sr(a) trabalhou?

$\square \operatorname{sim}$

$\square$ não (pule para q12)

8. no seu trabalho, o(a) sr(a) anda bastante a pé?

$\square \operatorname{sim}$

$\square$ não

$\square$ não sabe

9. No seu trabalho, o(a) sr(a) carrega peso ou faz outra atividade pesada?

$\square \operatorname{sim}$

$\square$ não

$\square$ não sabe

10. $\mathrm{O}$ (a) sr(a) costuma ir a pé ou de bicicleta de casa para trabalho:

$\square \operatorname{sim}$

$\square$ não (pule para q12)

11. Quanto tempo o(a) sr(a) gasta para ir e voltar do trabalho?

( ) menos que 10 minutos

( ) entre 10 e 19 minutos

( ) entre 20 e 29 minutos

( ) entre 30 e 39 minutos

( ) entre 45 e 59 minutos

( ) 60 minutos ou mais

12. Quem costuma fazer a faxina da sua casa?

$\square$ eu próprio

$\square$ outra pessoa (pule para 15 )

13. $\mathrm{O}$ (a) sr(a) costuma ter ajuda para fazer a faxina?

( ) $\operatorname{sim}$

( ) não (pule para q15) 
14. A parte mais pesada da faxina fica com:

( ) o(a) $\operatorname{sr}(\mathrm{a}) \mathrm{ou}$

( ) outra pessoa

( ) ambos

15. $\mathrm{O}$ (a) sr(a) costuma assistir televisão todos os dias?

\section{$\square \operatorname{sim}$ \\ $\square$ não (pule para q17)}

16. Quantos dias por semana o(a) sr(a) costuma assistir televisão

$\square 5$ ou mais

$\square 3$ a 4

$\square 1$ a 2

$\square$ não costuma assistir televisão

17. Quantas horas por dia o(a) sr(a) costuma assistir televisão?

( ) menos de 1 hora

( ) entre 1 e 2 horas

( ) entre 2 e 3 horas

( ) entre 3 e 4 horas

( ) entre 4 e 5 horas

( ) entre 5 e 6 horas

( ) mais de 6 horas 
ANEXO IV - Aprovação do comitê de ética

\section{COMITÊ DE ÉTICA EM PESQUISA - COEP/FSP \\ Universidade de São Paulo \\ Faculdade de Saúde Pública}

Of.COEP/ $093 / 07$

$\begin{array}{ll}\text { Protocolo } & 1658 \\ & \text { ASSOCIAÇÃO ENTRE SARCOPENIA, NÍVEL SÉRICO DE VITAMINA D, } \\ \text { Projeto de Pesquisa } & \text { CAPACIDADE FUNCIONAL E CONSUMO ALIMENTAR DE MULHERES } \\ & \text { IDOSAS COM OSTEOPOROSE } \\ \text { Pesqujisador(a) } & \text { Patricia de Souza Genaro }\end{array}$

28 de maio de 2007.

Prezado(a) Orientador(a),

O Comitê de Ética em Pesquisa da Faculdade de Saúde Pública da Universidade de São Paulo - COEP analisou, em sua 3.a/07 Sessão Ordinária, realizada em 25/05/2007, de acordo com os requisitos da Resolução CNS/196/96 e suas complementares, o protocolo de pesquisa acima intitulado, e o considerou APROVADO.

Lembramos, ainda, que conforme Resolução CNS/196/96 são deveres do(a) pesquisador(a):

1. Comunicar, de imediato, qualquer alteração no projeto e aguardar manifestação deste CEP (Comitê de Ética em Pesquisa), para dar continuidade à pesquisa;

2. Manter sob sua guarda e em local seguro, pelo prazo de 5 (cinco) anos, os dados da pesquisa, contendo fichas individuais e todos os demais documentos recomendados pelo CEP, no caso eventual auditoria;

3. Comunicar, formalmente a este Comitê, quando do encerramento deste projeto;

4. Elaborar e apresentar relatórios parciais e finais;

5. Justificar, perante o CEP, interrupção do projeto ou a não publicação dos resultados.

Atenciosamente,

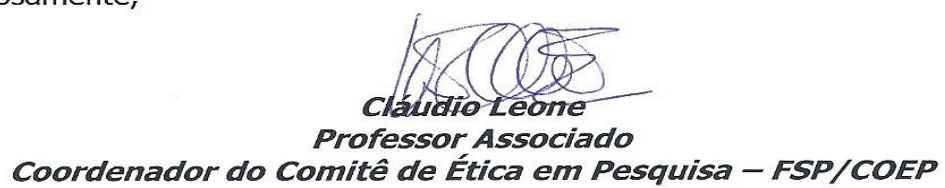

Ilm.a Sr.a

Prof. a Dr.a Ligia de Araújo Martini

Departamento de Nutrição

Av. Dr. Arnaldo, 715 - Assessoria Acadêmica - CEP: 01246-904 - São Paulo - SP

Telefones: (55-11) 3061-7779/7742 e-mail: coep@fsp.usp.br site www.fsp.usp.br 


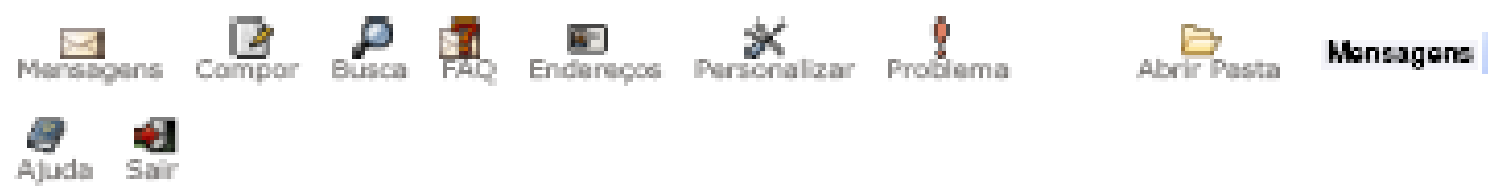

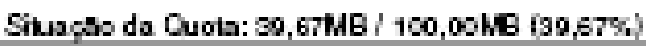

Mensagens: Enci RE: 09-017_de Souza Genaro_review of version 3 (21 de 21) 量

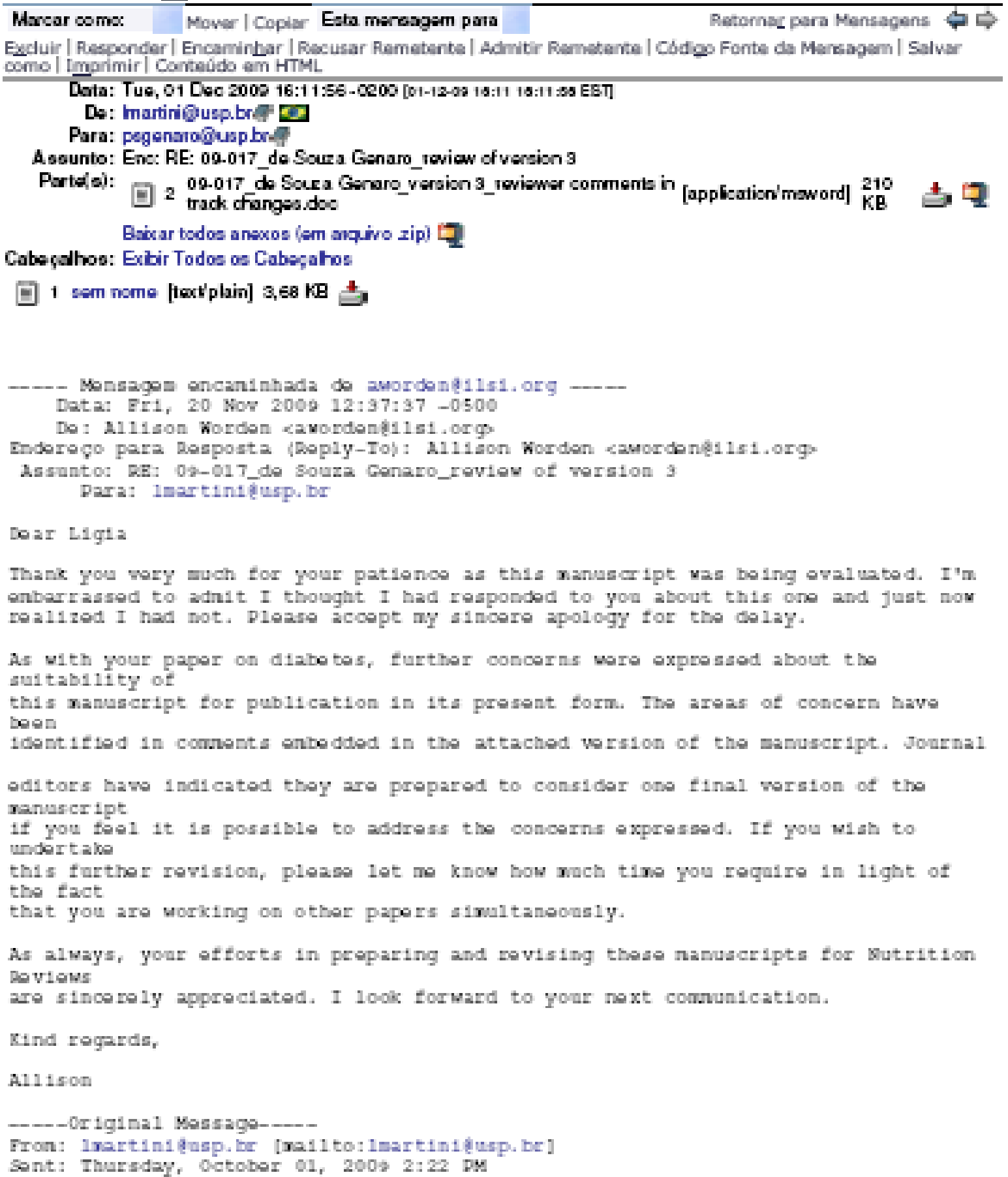




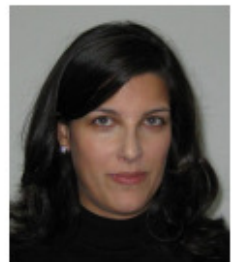

Patrícia de Souza Genaro

Bolsista de Doutorado do CNPq

Nutricionista formada pelo Centro Universitário Săo Camilo (2000), Mestre em Saúde Pública, área de concentraçăo Nutriçăo, pela Universidade de Săo Paulo (2005). Atualmente Doutoranda da Faculdade de Saúde Pública da Universidade de Săo Paulo e nutricionista do Ambulatório de Doenças Ósteo-Metabólicas da Universidade Federal de Săo Paulo. Experiência nas áreas de nutrição clínica, geriatria, osteoporose, composiçăo corporal e saúde coletiva.

(Texto informado pelo autor)

Última atualização do curriculo em 12/09/2009 Endereço para acessar este CV:

http://attes cnpq br'2361085685316211

Certificado

$12 / 09 / 09$

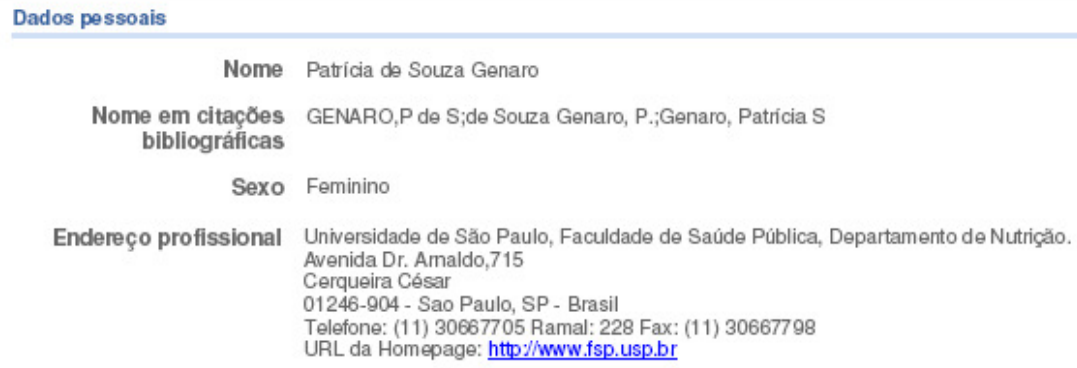

Endereço profissional Universidade de São Paulo, Faculdade de Saúde Pública, Departamento de Nutriçăo. Avenida Dr. Amaldo,715

Formaçăo acadêmica/Titulaçāo

2006 Doutorado em andamento em Saúde Pública (Conceito CAPES 5)

Titulo: Associaçăo entre sarcopenia, nivel sérico de vitamina, capacidade funcional $\theta$ consumo alimentar de mulheres idosas com osteoporose, Orientadon Lligia Araújo Martinid

Bolsista do(a): Conselho Nacional de Desenvolvimento Científico e Tecnológico, CNPq, Brasil.

Palarras-chave: Ostecporose; Consumo alimentar; Composiçao corporal; Vitamina D.

Grande área: Ciências da Saúde/ Área: Nutriçâa.

Grande área: Ciências da Saúde / Área: Nutriçâo / Subárea: Análise Nutricional de Populaçâo / Especiadidade: Consumo alimentar de populaçoes.

Grande área: Ciências da Saúde / Área: Nutriçao / Subárea: Bioquimica da Nutriçao.

Setores de atividade: Saúde humana; Nutriçăo $\theta$ alimentaçăo; Cuidado à saúde das populaçôes humanas.

2003 - 2005 Mestrado em Saúde Pública

Universidade de São Paulo, USP, Brasil.

Titulo: Avaliaçăo do consumo alimentar, composiçăo corporal e perfil do metabolismo mineral e óssecode mulheres na pós-menopausa com osteoporose, Ano de Obtençăo: 2005.

Orientador: (9) Ligia Araújo Martini.

Bolsista do(a): Fundaçăo de Amparo à Pesquisa do Estado de Săo Paulo, FAPESP, Brasil.

Palavras-chave: Osteoporose; Conșumo alimentar; Hipovitaminose D.

Grande área: Ci̊̊ncioso da Saúde / Área: Nutrigâ.

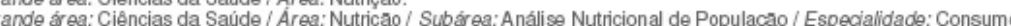

Gimentar de populacoes.

Setores de atividade: Nutriçao e alimentaçao; Cuidado à saúde das pesscas.

1997 - 2000 Graduaçăo em Nutriçăo

Centro Universitário Săo Camilo - Campus Pompeia, SAO CAMILO, Brasil.

Titulo: Tratamento Dietético A plicado à um paciente portador de Insufiêcia Cardiaca Congestiva Bilateral, Edema agudo de Pulmà̃o e Insuficiência Renal Aguda.

Orientador: Vera Silvia Fragellla.

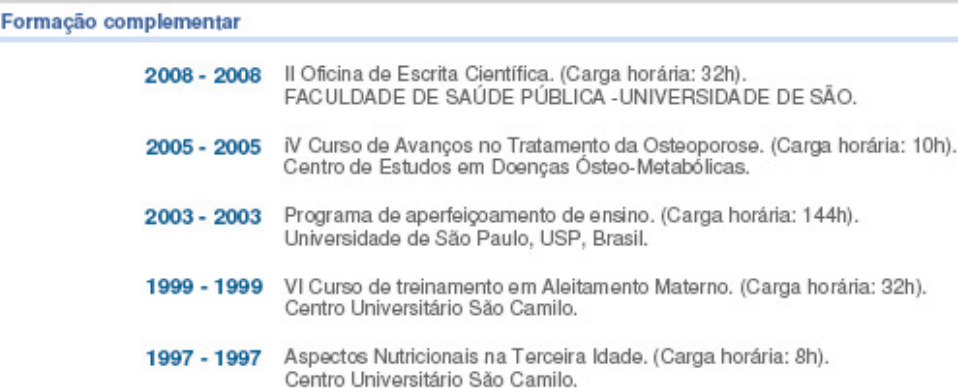

1997 - 1997 Aspectos Nutricionais na Terceira Idade. (Carga horária: 8h). Centro Universitário Săo Camilo. 


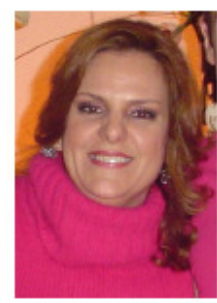

\author{
Lígia Araújo Martini \\ Bolsista de Produtividade em Pesquisa do CNPq - Nivel 2
}

possui graduaçăo em Nutricao pelo Centro Universitário Săo Camilo - Campus Pompeia (1989), mestrado em Nutriçăo pela Universidade Federal de Săo Paulo (1993) e doutorado em Nutriçăo pela Universidade Federal de São Paulo (1998). Realizou Pós-Doutorado no USDA Jean Mayer Hurnan Nutrition Research Cener on Aging at Tufts Univeristy - Boston MA. Foi Pesquisador Associado nivel 3 no Mineral Bioavailability Laboratory da mesma instituiçăao entre 2000 e 2001. Atualmente é Professor Associado da Universidade de São Paulo. É vice coordenadora do Programa de Pós-Graduaçăo em Nutriçăa em Saúde Pública da FSP - USP. Tem experiência na área de Nutriçăo, com ênfase em Nutriçăo e Doenç̧as Osseas, atuando principalmente nos seguintes temas: osteoporose, metabolismo mineral osseo, macadores bioquímicos da ingestão alimentar $\theta$ da composiçăo coporal, relaçăo entre dieta e doenças ósseas

(Texto informado pelo autor)

Última atualizaçáo do currículo em 14/12/2009

Endereço para acessar este CV:

http://attes.cnpq.br/1709520521624949

Cerfificado

pelo autor en

14/12/09

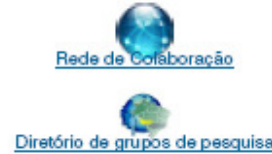

Diretorio de grupos de pesquis

Scip?o

SCIELO - artigos em texto

complate

\begin{tabular}{|c|c|}
\hline \multicolumn{2}{|l|}{ Dados pessoais } \\
\hline Nome & Ligia Araújo Martini \\
\hline $\begin{array}{r}\text { Nome em citaçø̃es } \\
\text { bibliográficas }\end{array}$ & MARTINI, LA;Martini, L. A.;Martini, Ligia A.;Martini, Ligia Araújo \\
\hline Sexo & Feminino \\
\hline Endereço profissional & $\begin{array}{l}\text { Universidade de Săo Paulo, Faculdade de Saúde Pública, Departamento de Nutriçăo. } \\
\text { Av: Dr. Arnaldo, } 715 \\
\text { 01246-904 - Sao Paulo, SP - Brasil } \\
\text { Telefone: (11) } 30617859 \text { Fax: (11) } 30617130\end{array}$ \\
\hline
\end{tabular}

\begin{tabular}{|c|c|}
\hline \multicolumn{2}{|c|}{ Formaçāo acadêmica/Titulaçāo } \\
\hline 2008 & $\begin{array}{l}\text { Livre-docência. } \\
\text { Universidade de Săo Paulo, USP, Brasil. } \\
\text { Titulo: Metabolismo ósseo: uma abordagem nutricional, Ano de obtençăo: } 2008 . \\
\text { Palavras-chave: Avaliaçao Nutricional; densidade mineral ossea; doença óssea. }\end{array}$ \\
\hline $1998-2001$ & 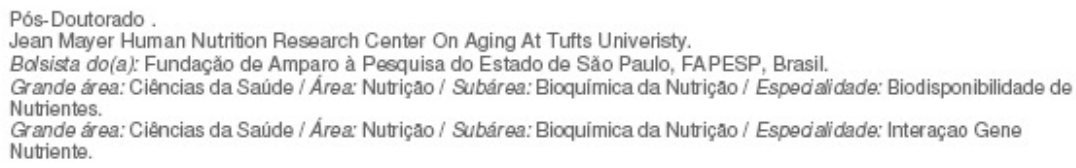 \\
\hline 1994 - 1998 & $\begin{array}{l}\text { Doutorado em Nutriçăo. } \\
\text { Universidade Federal de São Paulo, UNIFESP, Brasil. } \\
\text { Titulo: Influencia dos fatores dieteticos sobre a massa ossea de pacientes litiasicos, Ano de Obtençăo: } 1998 .\end{array}$ \\
\hline & $\begin{array}{l}\text { Orientador: (9) profa Dra Ita Preferman Heilberg. } \\
\text { Bolsista do(a): Coordenaçắo de Aperfeicoamento de Pessoal de Nivel Superior, CAPES, Brasil. } \\
\text { Palavras-chave: dieta; densidade mineral ossea; litiase renal; hipercalciuria. } \\
\text { Grande área: Ciências da Saúde / Área: Nutriçáo / Subárea: Bioquímica da Nutrição. } \\
\text { Setores de aúvidade: Cuidado A Saúde das Pessoas. }\end{array}$ \\
\hline \multirow[t]{2}{*}{$1991-1993$} & $\begin{array}{l}\text { Mestrado em Nutriçăo. } \\
\text { Universidade Federal de São Paulo, UNIFESP, Brasil. } \\
\text { Titulo: Avaliacao da ingestão de nutrientes litogenicos em pacientes litiasicos, Ano de Obtençåo: } 1993 .\end{array}$ \\
\hline & 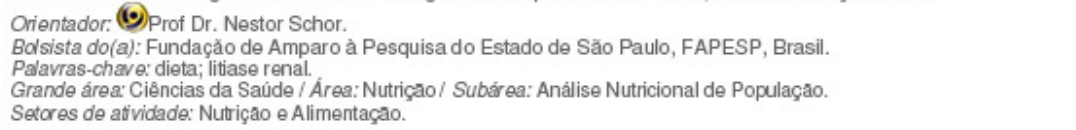 \\
\hline $1985-1989$ & $\begin{array}{l}\text { Graduaçăo em Nutricao . } \\
\text { Centro Universitário Săo Camilo - Campus Pompeia, SAO CAMILO, Brasil. }\end{array}$ \\
\hline
\end{tabular}

\title{
Atuação profissional
}

Universidade de São Paulo, USP, Brasil.

Vinculo institucional

2001 - Atual Vínculo: Professor, Enquadramento Funcional: Professor doutor, Carga horária: 40, Regime: Dedicaçăo exclusiva.

Atividades 